
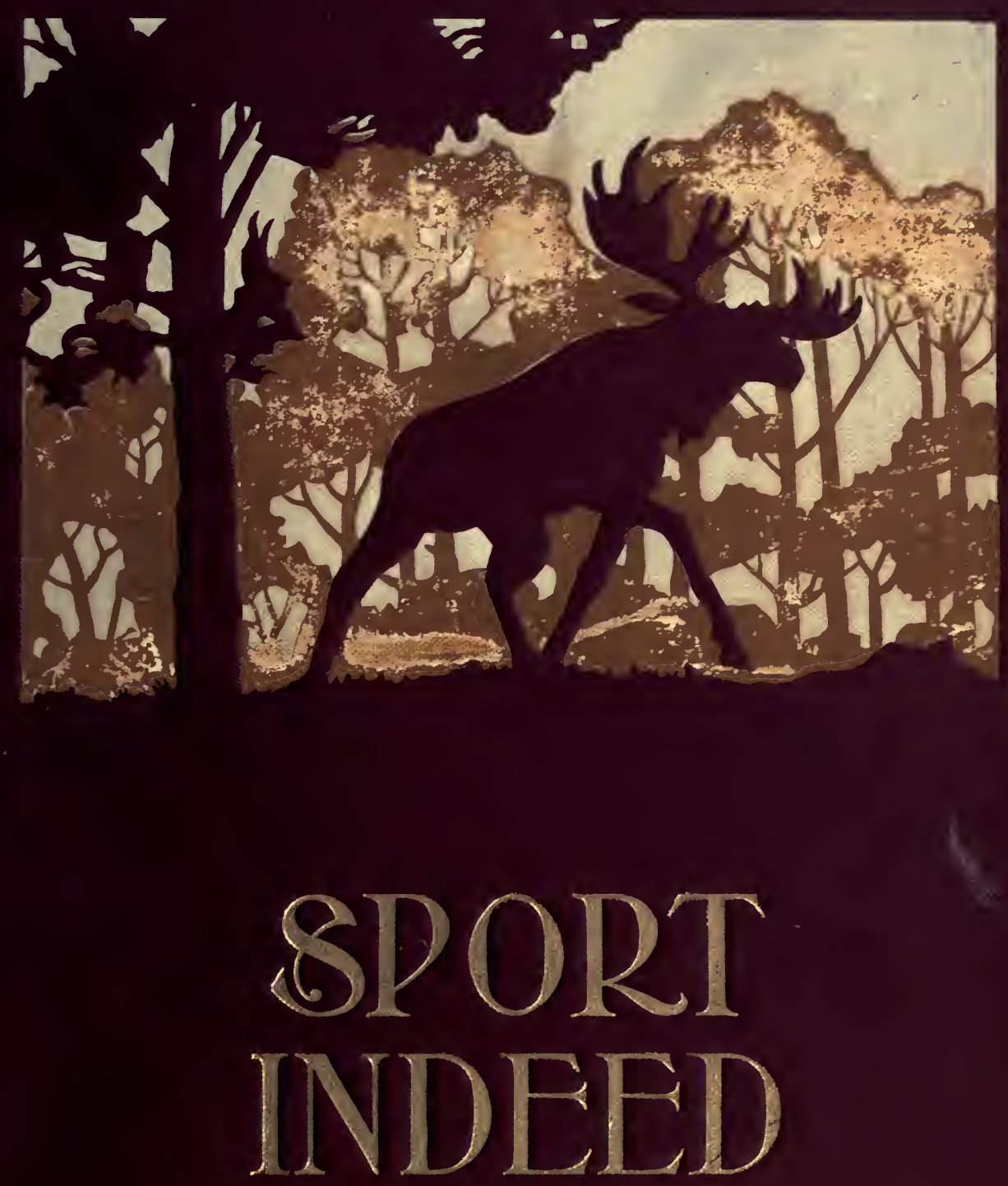

THOMAS MARTINDALE 


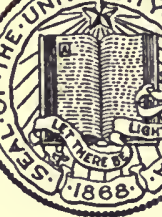

THE LIBRARY

OF

THE UNIVERSITY

OF CALIFORNIA

LOS ANGELES 


$$
\begin{aligned}
& x, e \\
& 300
\end{aligned}
$$



- 


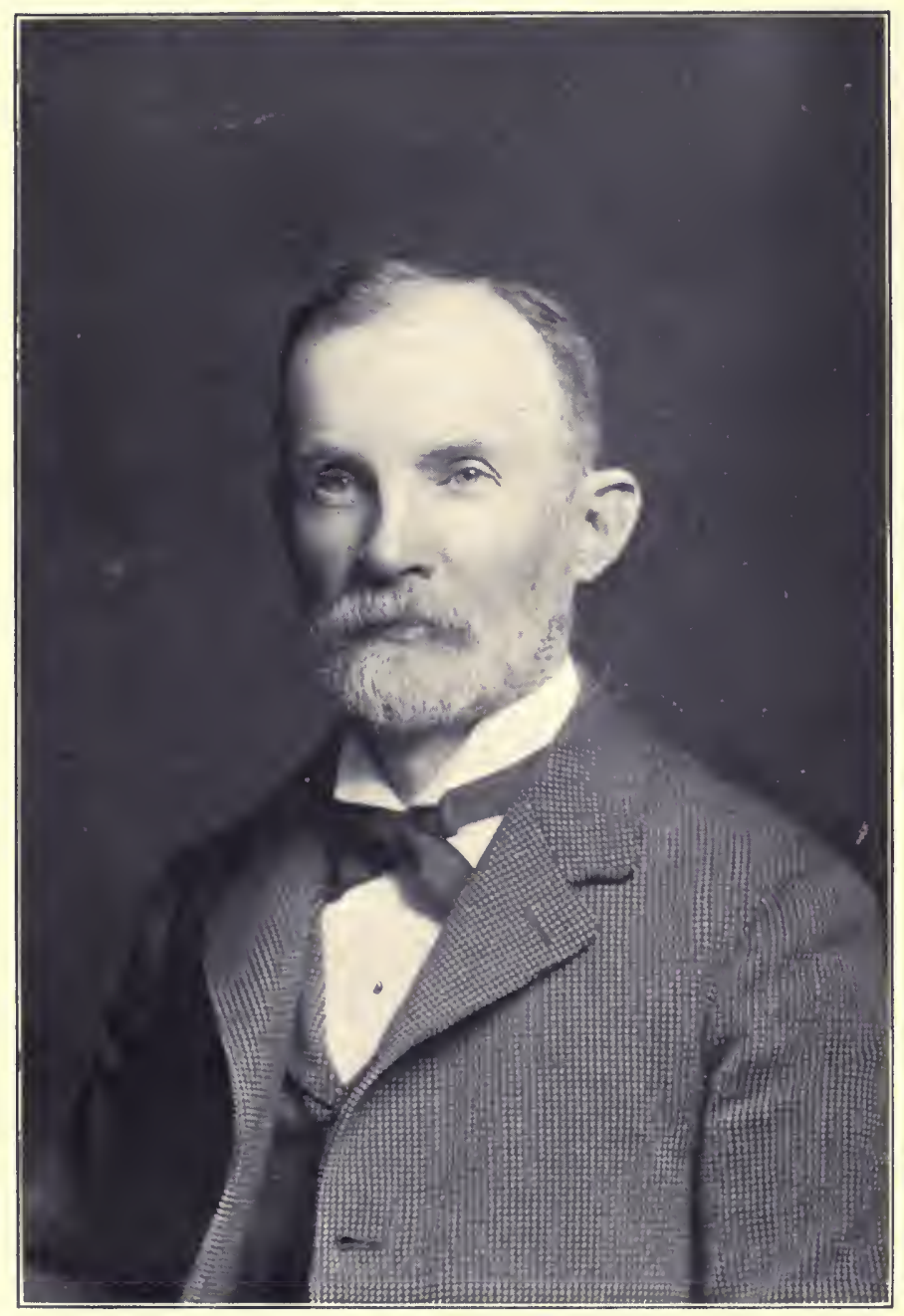

Thomas Martindale 


\section{Sport Indeed}

\section{By \\ THOMAS MARTINDALE}

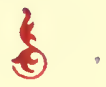

With illustrations

from photographs

by the author

PHILADELPHIA

GEORGE W. JACOBS \& CO. 103-105 South Fifteenth Street 


\section{Copyright, 1901 \\ By George W. Jacobs \& Co}

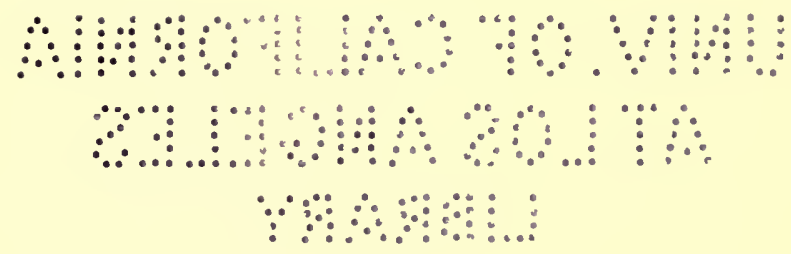


崫 IN this devil-may-care age the dedication of a book can hold but little interest for the reader. The custom has grown somewhat stale, and stale customs, like stale things generally, are unpalatable. Nevertheless, it is a gratification to me to dedicate this one * to my son James, who, in his love for the huntsman's in sport, is a nimble follower in the footsteps of his sire 흐 and a promising chip of the old block.

T. M. 
Digitized by the Internet Archive in 2007 with funding from Microsoft Corporation 


\section{APOLOGETIC}

IF it be true that "good wine needs no bush," it ought to be true that a good book needs no apology. "But," my reader may ask, " is your book a good one, or does its goodness rest only on the modest opinion of its author?" Dear reader, I may safely say, without stretching the bounds of modesty, that any book whose aim is to lengthen and make better the life of the American business man and to show him the most enjoyable way to do it must be a good book. "But why the American business man rather than another?" Because he is the man whose manner of life affords the broadest room for improvement. He is the man who in his fierce chase after the almighty dollar forgets that there are such things as health and happiness and personal comfort, or if he remembers them it is only to see that they step aside and stand not in the way of his chase. To stop for rest or for recreation would be extravagance, especially as he knows no need of either. A knowledge of the need, however, is sure to come, and when it does he may thank his stars if it has'nt come too late. You cannot teach an old dog new tricks nor can you disentangle the habits of a lifetime from 
their worry and care and weave the worn threads into youthful toggery.

Too late! Too late!

I am aware of the dangers that lie in wait for the book-writer. "Oh, that mine adversary had written a book!" was the burden of Job's prayer, 3,500 years ago, and it is doubtful whether the roll of passing centuries has flattened the peril. However, flattering myself that I am no man's adversary, I will take the risk and launch my volume, hoping for it fair weather, faroring gales, and a broad harbor from which to spread its wholesome freight wherever it may do the most good. 


\section{CONTENTS}

PAGE

DedichtorY . . . . . . . . . . . . . . . . 3

A pologetic . . . . . . . . . . . . . . . 5

Moosehead Lake . . . . . . . . . . . . . . . . . 11

Cupid in the Wilderness . . . . . . . . . . . . . . . . 19

Calling the Moose . . . . . . . . . . . . . . 25

AN Unexpected Treat . . . . . . . . . . . . . . . 33

Killijg the Caribou . . . . . . . . . . . . . . . . 36

More of the Moose . . . . . . . . . . . . . . . . 45

A Lost Man and a Wounded Moose . . . . . . . . . . 52

A Capriciods Beast . . . . . . . . . . . . . . . 64

My First Bull-Moose . . . . . . . . . . . . . . 74

A Caribou Hunt . . . . . . . . . . . . . . . . 85

A Lost Mloose . . . . . . . . . . . . . . . . . . . . . 96

The Big Moose of Little Tobique . . . . . . . . . . . . 101

The Lost Wallet . . . . . . . . . . . . . . . . 125

A Close Call . . . . . . . . . . . . . . . . . . . . 132

The Fun of Hunting . . . . . . . . . . . . . . . . . . . 149

A Fire-and-water Medley . . . . . . . . . . . . . . . 156

A DAY IN THE BIG WoODS . . . . . . . . . . . . 161

A DEAD-WATER Vigil . . . . . . . . . . . . . . 174

Dog-DAY ADVICE . . . . . . . . . . . . . . 186

A Tale of Gallantry and Hunger . . . . . . . . . . 190

A Beardless Sport . . . . . . . . . . . . . . . 204

A Treacherous Coward . . . . . . . . . . . . . . 211

The Great Northwest . . . . . . . . . . . . 227 
8

Contents

PAGE

NoRth DAKotA . . . . . . . . . . . . . 273

THE WRECkER . . . . . . . . . . . . . . . 278

Brant Shooting . . . . . . . . . . . . . . 284

The Quaint Cape-Codders . . . . . . . . . . . . . 290

A WARY BIRD . . . . . . . . . . . . . . . . . 295

Quall Shootixg in North Carolina . . . . . . . . . . 301

"Trout Tickling" ANd an Old-Exgland Blizzard . . . . 310

A Dangerous Ride . . . . . . . . . . . . . . . . 318

A Fight to the Death . . . . . . . . . . . . . . . . . . 326

A Pilgrimage to the "White" . . . . . . . . . . . . . . . 332

The LAST ShOT . . . . . . . . . . . . . . . . . 344 


\section{ILLUSTRATIONS}

Thomas Martindale . . . . . . . . . Frontispiece. PREPARING FOR THE START . . . . . . . . . Page 13 A Log Landing on the Brook . . . . . . . . . . " 37 His Lordohip ; as Grand a Specimen as the Sun Ever SHONE UPON . . . . . . . . . . . " 41

The Dry bog-a Favorite Haunt of the Caribou . . " 53 A Camp in the Wilderness . . . . . . . . . . . . . . " 61 The Canp in Its Winter Beauty . . . . . . . . . . . " " 69 My First Mloose . . . . . . . . . . . . . . . . . . . " 81

A Bit of Maine Forest-Penobscot River in the Distance . . . . . . . . . . . . . . . . " " 89

The Culinary Departuent of a Hunter's Cayp . . . " 107

A New Brunswick Tote-road . . . . . . . . . . " 119

The Frozex Penobscot . . . . . . . . . . . . . . " 129

A Scene on the Pexobscot . . . . . . . . . . " " 135

A Tote-road in Winter . . . . . . . . . . " 141

A Beaver House . . . . . . . . . . . . . . " 163

A Hunter's Forest Hone . . . . . . . . . . . . “ 169

A DeAD-Water . . . . . . . . . . . . . . . " 179

LABORIOUS WORK. . . . . . . . . . . " 193

The Litthe Tobique . . . . . . . . . . . . " " 201

A Youthful Hunter . . . . . . . . . . . . . " 207

Precious Trophies, Including the Little Spike Horx " 219 The Axgler's Paradise . . . . . . . . . . . . “ 259

A Fine Trophy . . . . . . . . . . . . . . “ " 313

Ax Exciting Chase . . . . . . . . . . . 335 



\section{Moosehead Lake}

This way lies the game.

-King HeNry VI.

WE left home on a Saturday night in September, by the 6:50 express, with the wilderness of Maine for our destination. The night was hot, close and miserably uncomfortable. The sleeping-car felt like an oven and before we reached New York we turned into our berths, as that seemed the coolest thing to do. Sunday in Boston was rainy and cold, and when we arrived at Bangor we had to put on heavy flannels and get out overcoats.

It was election day in Maine; yet, although it was expected that the Republican ticket would be elected by 30,000 majority, we saw no excitement along the railroad in our ride from Bangor to Greenville, at the head of Moosehead lake. No bands, no men with badges on, pottering around polling places. An occasional flag floated on the frosty air, but that was all. Yet there was a silent, unseen something foretelling that an enormous Republican vote would be polled-and it was. During our ride in the car a prophetic native sitting behind us broke loose in this fashion: "If it weren't for one thing, darned if I wouldn't bet a dol- 
lar to a penny doughnut that the State would go u-nan-i-mus for Powers."

"What thing?" asked his companion.

"Why, some smart cuss might hear of my bet and vote for t'other fellow so as to make me lose it."

There are a number of little steamboats on Moosehead Lake, which ply backwards and forwards, carrying freight and passengers. Upon a time-card, a sort of free-and-easy-go-as-you-please schedule, we were told our boat would leave promptly at six in the morning. So on Tuesday we were up before five o'clock in order to see that our stores, baggage and hunting outfit were aboard on time. Then we had breakfast in a hurry, first asking the landlord to tell the captain of the boat that we would be aboard at six and not to start without us. At six we were pacing the deck of the steamer, listening to the captain and pilot piling their "cusswords" on the head of the engineer for not making his appearance. As the boat couldn't well go without an engineer, we waited. Half-past six came and still we waited. The whistle was blown repeatedly, but it brought no sign of the man who handled the stopcocks. At eighteen minutes to seven we saw the stopcock knight coming down a hillside as leisurely as if he were an hour ahead of time. He came aboard and we made a start, crossing to another landing where we took in tow a scow with four horses, a party of ladies and some lumbermen. At a quarter to eight we were 


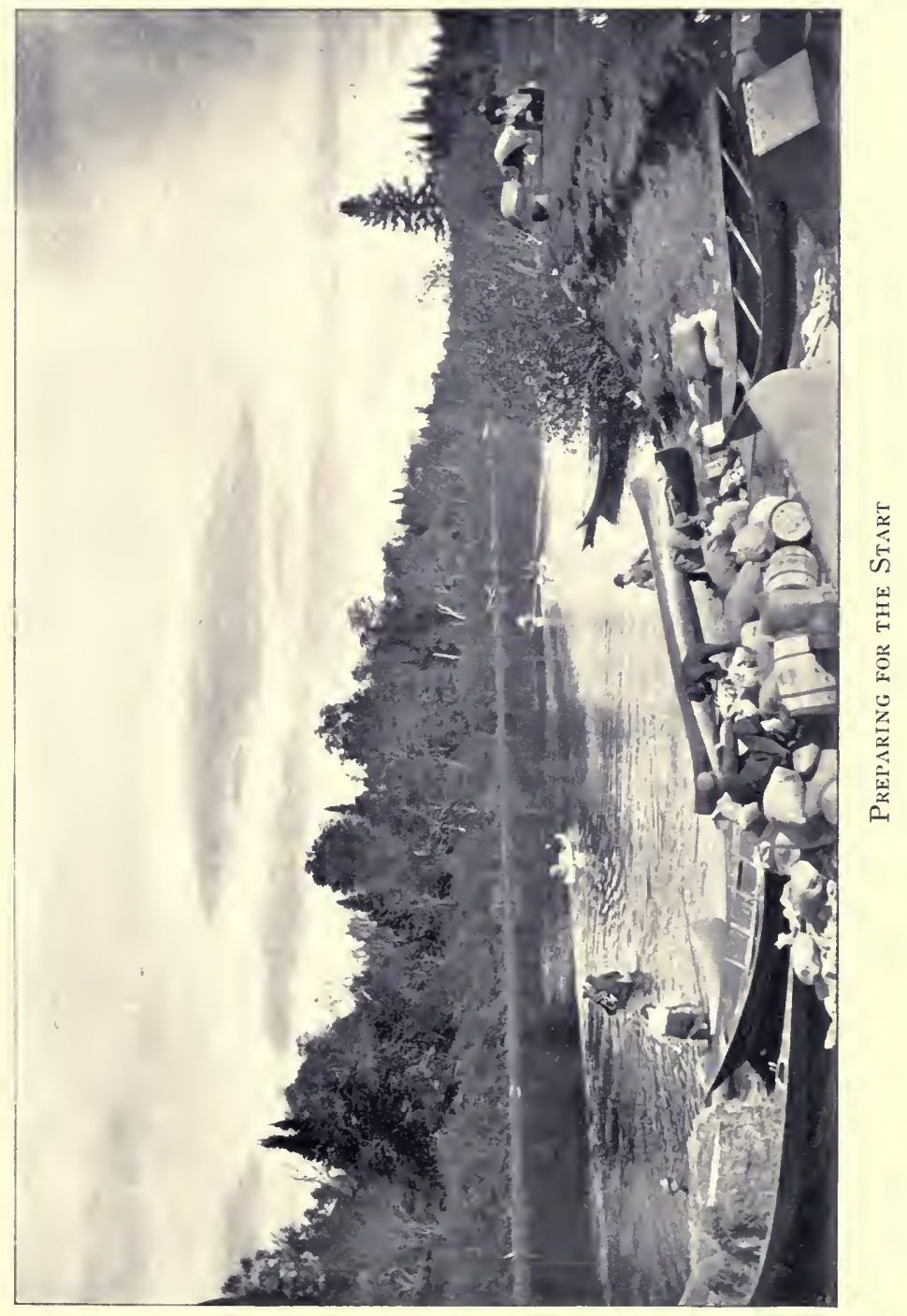



off for the Northeast Carry, where we arrived about an hour and a half late, which hour and a half caused us afterwards an exciting time.

Northeast Carry is so called because it is a road or "carry" at the northeast end of the lake. The carry is two miles long, and the other end of it lands you on the banks of the Penobscot River. While we were loading our canoes a party from down the river reached our landing. In the centre of one of their canoes a lady was seated on a throne-like chair which was covered with costly Persian rugs. Luxurious aircushions supported the lady's back and formed a rest for her feet. An oriental robe, tinted with all the hues of the rainbow, was gracefully thrown around her dainty limbs, mingling its colors with those of the autumn leaves which were strung in garlands about the bow of the boat. A pretty picture, indeed, but yet imperfect. It needed a dusky Indian maiden, with no clothes on to speak of, waving a peacock fan. Then the picture might have passed, on a pinch, for that of the proud Cleopatra as she sailed up the Cydnus to tickle the fancy and ravish the heart of her Antony.

Precisely at two o'clock the next day we paddled away from Northeast Carry. We had a glorious run to the Half-way House, ten miles down. The river scene was bewitching in its beauty. The first frosts had delicately colored the leares of the maple and 
beech, while the waving masses of ferns that fringe the river's edge had changed their greens for various shades of yellow and brown, and spread their dainty texture along the banks as if anxious to show what nature could do in the way of embroidery.

Everything looked radiant and happy-save our three guides who were taciturn and troubled. The reason was plain. It was half-past four in the afternoon when we reached the Half-way House. We had stated that we desired particularly to be at Chesuncook Lake (twenty miles down the river) that night, and there would have been no trouble in making the journey by daylight if the steamer Comet had been more prompt in starting from Greenville. Now, below us, six miles down, is a great stretch of rapids called the Rocky Rips, a mile and a half long. Below these rapids come the Pine Stream Falls, half a mile long.

Our three canoes were deeply loaded. Should we risk the run or not? It was finally decided to risk it, and away we went; but with all our lively paddling it was dark when we reached the head of the Rips, and we were in for it.

'Tis a beautiful sight in daylight to see the canoes on these rapids rushing one after the other from shore to shore, dodging this rock, sliding over that shelf, or doubling around some intruding ledge, all the while striving to keep in the channel which in some places is 


\section{MOOSEHEAD LAKE}

not more than four or five feet wide. At night, however, the sight is not quite so captivating, especially if the night be a dark one and you happen to make up a part of the canoe's cargo.

We got through, however, without any greater mishap than breaking the rib of one canoe and shipping some water into another. A few minutes after emerging from the boiling Rips we heard the roar of the falls about a mile further down. The sound was grand, and we thought we were going to have another exciting run. In this we were disappointed. The guides said that, in order to lighten the canoes, we sports would have to get out and walk through the woods to the bottom of the falls-about half a mile. They then rearranged the loads and started down the falls by water while we went down by land; and it was darker in the woods than it was on the river. We stumbled and tripped over roots and logs, while the guides stumbled and tripped over rocks. We managed to get through and so did they, after a fashion. One man had to jump out of his canoe to save it and another man brought his down leaking. Neither man seemed happy. However, there is very little pure happiness in this world and perhaps the adulterated article tastes all the better for its mixture with a little misery.

In a few minutes the loads were changed and we were off again down the river. After a run of about an hour we saw the lights. of the Chesuncook House 
looming up bright and cheery in the distance, and in a little while we stood within its hospitable doors. We found it full of sports and their guides, and among the former was a goodly proportion of "lady sports." No less than four of the short skirt variety ; and these, with their little rifles, their little boots, their little Jerseys, their little fishing rods and their little "fellers," made the scene an interesting and we might say-although hanging should be the penalty for such a pun-an amooseing one. 


\section{Cupid in the Wilderness}

This love will undo us all. O, Cupid! Cupid! Cupid!

-Troilus axd Cressida.

Human nature is the same the world orer, and Cupid, sly dog that he is, appears to know that the wild woods and lakes and rivers of Maine are no exception to the rule. $\mathrm{Ah}, \mathrm{me}$ ! if these same woods and lakes and rivers had tongues and knew how to use them, what queer tales they could tell and what incidents might come to light that now slide into the past unstoried and unrecorded!

Here, in this very wilderness, hunting, fishing and pleasure parties yearly congregate, and among the latter is plenty of fit food for Cupid's powder-young and beautiful girls with enough will, skill and ingenuity to paddle their own canoe and make love at the same time, if their chaperons be sleepy enough to permit the performance of such a double-barreled programme.

These fishing and pleasure parties remain no longer than the middle or latter part of September; but while they're here, the little, winged god is up to his chin in business, and to be hit with one of his arrows is as common as trouble. Ah,

"Cupid is a knavish lad

Thus to nuake poor females mad." 
But, with all due respect to William Shakespeare, I would remind him that it is not from out the female sex alone that Cupid chooses his candidates for the madhouse. The "knavish lad" is no respecter of persons or sex, as the immortal William would discover if his canonized bones could burst their cerements, quit their narrow bed and visit this summer habitat of the curly-headed god.

Now I come to think of it, William's bones need not go to that trouble. The sad, lamenting tone of his words :

"O, love's bow shoots buck and doe,"

proves that he knew the ambi-sexibility of Cupid's tricks quite as well as he seems to have known everything else.

Funny indeed are some of the doings of engaged couples. Here is an instance, and I hope the interesting couple with "hearts that beat as one" will pardon me for giving it away to the cold and unappreciating world. They made the sad discovery that their canoe was too small to hold an embryo bride and her best young man at the same time; but love, that "laughs at locksmiths," surely would not cry at a less serious emergency. Its resources are much too ready for that. They placed two canoes side by side, bound them together with a pair of encircling arms and, with a guide to paddle in the stern of each love-laden vessel, went on their way rejoicing. 


\section{CUPID IN THE WILDERNESS}

Now these guides, while they know how to paddle, know quite as well how to tattle, and tattle, in truth, they do

Of the doings and the wooings,

Of the billings and the cooings,

Of the kissings and the huggings of the pair ;

Of the lovings, of the scoldings,

Of the rapturous enfoldings -

Oh, Paradise with lots of fun to spare!

Of course, the guides are only mortals, and, as all this takes place within their easy eye-and-ear-shot, they would be more than mortals-or less-if they didn't tattle. Bless your heart, the amount of it they have retailed to me might fill a book the size of Webster's Unabridged. You shall have the benefit of it some day, as I intend to pick out a few of the best, the very best, of their stories and print them. Then, look out for something rich and racy; but not now. We will first allow these turtle doves time to mate and settle in their nest.

A new crowd of visitors had appeared in the Maine woods and waters-visitors who were bent on killing the succulent deer, the solitude-loving caribou and the lordly moose - the noblest Roman of them all.

These visitors, by the force of circumstances, were obliged to have guides whose particular policy it is to speed the parting "sport" and welcome the coming one. In the various places where these guides meet -Greenville, Kineo, Northeast Carry, Chesuncook 
House, Mud Carry, Eagle Lake or Churchill Lake and hundreds of other places-there is always a comparing of notes of the many things said and the many things done by the departed guests. As I have already hinted, I may at some future time give you the pith of a few of these notes.

It was surprising how many men were already in the woods for the fall hunting, which starts October first, and how many more we heard of that were coming. Every hotel register was well sprinkled with names of residents of the Quaker City, more, I think, than from any other place. Here is how I came in contact with one of them. One of my guides hurt his knee, and so much that his limb swelled to double its natural size. I was considering how I could send him home, and as this would require a canoe journey of five days, with five more for the return of the guide who took him out, the matter to me was a serious one. He relieved my mind, however, by telling me he had heard of a doctor who was camping at the head of a bog a few miles away. I put my man at once into a canoe and paddled up to the tent of the Esculapian disciple whom I found to be an eminent one and a Philadelphian. After looking at the man's damaged limb he said: "Well, I am an expert, or considered so, on insanity, and perhaps on one or two other of nature's calamities, but I am not an expert on swelled legs. However, this is what I advise you to do." 


\section{CUPID IN THE WILDERNESS}

And he told him. The doctor's advice seems to have been-what a doctor's advice sometimes is not-the proper thing, for the leg got well. But before the man could call again to thank him for his mended leg, the learned leech had vanished in the depths of the wilderness and we saw him no more.

The natives hereabout are, in money matters, what the Scotch call canny. And some of them are canny enough to give any Scotchman points and beat him with ease. Listen to this. A storekeeper, "a native here and to the manner born," had a mother. I don't wish you to infer, however, that he differed in this particular from any other storekeeper. He was a dutiful son and doted on his mother, showing her every mark of filial affection. This was, of course, very commendable in him; but she deserved it all, for report says she was a "grand woman." In the course of human events the old lady became "worrited." Life's cares and troubles came so thick and fast that they began to choke up the oil in her lamp of life. It commenced to flicker and grow dim and needed only a puff of apoplexy to put it out entirely. When the end came the son's grief was touching, and the more so as there was no place where he could obtain a coffin nearer than a town three days' journey away. The problem how to get there and back in time to bury the old lady decently troubled his mind, for the indecency of burying her in one of their common pine 
receptacles was more shocking to his delicate sense of propriety than planting her in a dry-goods box. At this juncture a man who had long known and revered the departed woman volunteered his services to fetch a coffin. With sturdy strokes of his paddle in the dead waters of the river and the deft use of the pole in pushing up over the quick ones, he hurried on. After reaching a carry, he ran the two miles across it in order to catch the first boat to the town where coffins were for sale. Making his purchase he shouldered it and hustled his way back; then putting the coffin in his canoe he started down the river as rapidly as elbow grease and paddle could drive him. When he landed, the son of the old lady asked him what his charge would be for the trip. The man replied that he would make no charge, that the deceased had always been kind to him, and what he had done was little enough to show the good-will and respect he had for her. "I am glad," he said, "to have had the chance to do what I have done; but I wouldn't mind having a plug of tobacco; mine was all used up on the trip." The dutiful son handed him a plug from behind the counter and in the most kind-hearted tone said : "Ten cents, please." This he said and nothing more. 


\section{Calling the Moose}

This is excellent sport, i' faith.

-HeNRY IV.

In the latter days of September and the early weeks of October the mammoth deer, known as the moose, is mating. Then it is that the woods of Maine, Nova Scotia and New Brunswick are traversed by thousands of sportsmen with their guides, all in search of one thing - a chance to kill a bull-moose. Now, the female moose, in one particular, is very like some other females of the animal kingdom; she is coy and capricious, leading her lover "a merry dance o'er moss and fell," through bog and swamp, and along the margins of lakes, ponds and lagoons, or "logans" as they are called in this region. At night she comes down to the water to feed on the roots and tops of the lily-pad which grows so abundantly in sluggish streams. If her mate is her escort he usually stands on the bank, eyeing his spouse tenderly as she feeds, and ever ready to protect her from all danger, real or fancied.

If the bull-moose has no cow of his own, but is merely ranging and scouring the country to find a sweetheart that fits his fancy, then is the time he is 
apt to fall into a trap and a very sure one. On a still night-and, mind you, the night must be still-around every lake, pond and river where the moose frequents and feeds, the bull hears the sounds of sweetest melody-sounds filled with such plaintive tones and such a come-to-my-arms sort of cadence that he cannot resist the appeal. These sounds are termed the "call," and their ascending and descending notes are produced by the guides, their instrument being a birch-bark horn. If the call be well made it will be heard by the bull miles away. Pricking up his ears he will start on the run, thrashing through the brake, barking, bellowing, grunting and in his own affectionate manner answering the impassioned notes of his counterfeit mistress. When he reaches the edge of the wood he grows wary and suspicious. He will steal up and down among the bushes, listening and scenting in a she-may-be-fooling-me sort of way; and sometimes it takes many nights to convince him that be is the very gentleman the lady moose is "stuck on," and for whom she is so lovingly calling. Alas, how many a bull-moose Lothario falls a victim to his own vanity and the alluring notes of a birch-bark horn!

Although the bull-moose is a thoroughbred Mormon, having sometimes as many as five wives in his harem, yet when he has one of them specially under his protection he will hardly leave a bird in hand for one in 
the bush. I have myself heard him answer a call while engaged in his protective duty and then make a start, which in this instance was for two miles; but the loving voice of the real moose arrested the wanderer and brought him back to the family bosom. I heard and saw all this, - saw him approach the water, step into it and splash it with his feet, meanwhile looking cautiously around as if he scented danger in the air. And there was danger, and a good deal of it. In the front of a canoe sat a hunter with rifle ready cocked, and heart throbbing with thumps that threatened to burst the buttons off his coat. A moment of breathless suspense, and then bang! goes the $45-90$ cartridge, the report sounding and resounding through the woods and over the waters for miles around. There was another bang and yet another. Whether the uncertain light or the uncertainty of the hunter's aim, due to his sitting for hours still as a mouse and in an atmosphere with the thermometer at freezing point, had anything to do with the result, I can't say. But I can say that the moose escaped unharmed-untouched by the bullet that might have forever put an end to his midnight prowlings and Don Juanish intrigues.

The sport of moose hunting is one that requires a great deal of patience and perseverance from the hunter, and under such trying difficulties as exposure to cold and loss of sleep. But his reward is ample- 
plenty of excitement, and, if successful, a magnificent antlered head as a trophy of his prowess.

One night my guide and I set out to paddle up the inlet of a little lake we were encamped upon, with the intention of calling if it should be still enough to do so. There was some wind on the lake, but we thought there might be little or none in the forest-sheltered inlet. I was tucked down in the front of the canoe with blankets to keep my legs warm (for the night was cold), with heavy woolen socks drawn over my boots and a woolen cap down over my ears. We paddled about a mile and found the wind worse than it was on the lake below, and strong enough to make it hard canoeing. In a big bog on the right-hand side we heard a branch brake. We stopped and listened. A deer, we thought, as another and another branch broke. Then came the sound of heavy footfalls and we knew a moose was "coming to the water." We listened intently-so intently that I could hear the ticking of $\mathrm{my}$ watch, though it was buried under a siveater, a coat and an overcoat; nay, more, I heard -perhaps it may have been fancy-the stretching of my elastic suspenders as I breathed. Soon we distinguished through the dark of the moonless night a great object, big as a hippopotamus, move down the bank and step into the water. The guide pushed up the canoe deftly and silently, but the wind was at its worst at this time and blew the canoe diagonally 
against a tree-top sticking out of the water on the other shore. This made a noise, little, it is true, but yet it seemed, oh, how great! Just then we saw another huge object on the bank. Now, up to this time, we could not make out whether the monster in the water was a bull or a cow-moose, and it was rather important to know which, as a fine of four months' imprisonment is the penalty imposed in Maine for shooting a cow.

It was so dark that I could not see whether the big object had horns or not; but the guide settled the problem with: "be quick! that's him on the banknow down him!" I raised my rifle, aimed for what I believed to be his shoulder, and pulled the trigger. Horror of horrors! the hammer wouldn't budge. Again I sighted and pulled, and yet again, but all to no purpose. My rifle was more harmless than a pocket pistol loaded with Jersey applejack. The cow soon took alarm, floundered up the bank and in the twinkling of an eye both were gone; he bellowing and barking through the alders and crashing down everything before him in his fury; and she silently stealing a way in the darkness.

There were two very disgusted men that night; one because the other didn't shoot and the other because his rifle wouldn't let him shoot. On coming into camp I made an examination of the trouble and found that on account of several days' steady rain the 
lock of the rifle had become so rusty, although greased every day, that it would not work. To this that bull moose owed a little longer lease of life. A job also awaited a gunsmith, if one could be found capable of taking a rifle apart and teaching it to obey the trigger at least one time out of three.

We had been in these northern woods of Maine for over three weeks. In that time there were, I think, but two fine days. The rest were made up of winds, rain, snow and ice; winds from all points of the compass; winds that would start with the strength of a gale, then soften down to the breath of a zephyr. Still they were winds, and we had them of every variety-you see we were "moose calling," and you cannot call moose successfully in windy weather; that is the reason we noticed the wind. Rains? Yes, of all degrees and conditions; soft rains and hard rains, gentle rains and furious downpours-one of which, at the time I speak of, was having things its own way. My guides were building a break-rain, break-weather, break-water-or whatever you may please to call itof fir trees, and planning where to put the door ; but, as the rain seemed to blow from everywhere, there was more promised comfort in leaving out the door and carrying the fir grove entirely around the camp.

During this miserable, rainy spell I watched the game with some interest-what little of it I had been able to see-to learn how they relished the damp 
humor of Jupiter Pluvius. They seemed to fancy it no more than do their enemies, the human bipeds.

In my watching I observed some partridges huddled under a big log, with feathers wet and all the glory of their color and fluffy sleekness departed. The cock bird looked woe-begone and cheap and ragged-a dripping, melancholy shadow and I thought of the poet's lament:

\section{"Shades of the mighty can it be That this is all remains of thee?"}

Once I started a deer from out a clump of young pines where he had been sheltering himself. Again, I came across an old doe standing under a couple of big cedar trees, and after she had "lit out" I stepped into her arbor and sat down. Although the rain was falling in streams, yet none fell on me and I spent there a couple of happy hours watching the capers of the only living things that had the courage to brave the storm - the red squirrels. They were busily occupied in laying up their winter stores, which seemingly were to consist of pine cones, as each lhad one of these in his mouth. I noticed they took good care to run along the ground under the logs, and not on top of them.

We took the weather philosophically, because we were well prepared for it. We had plenty of dry clothes, a big camp to shelter us, a roaring fire, an abundance of the finest game in the world to eat, clear, mineral-spring water to drink, good appetites, 
and rugged strength to take a daily tramp whether the weather was what it ought to be or whether it wasn't.

It was said that at least fifteen hundred sportsmen were then in the Maine woods. If so, they required fully two thousand guides, making an army of say three thousand five hundred people, many of them with only a week or ten days' time at their disposal, and some of them accompanied by ladies. While the weather-look was bad for us, it was worse for "the other fellers," whose short supply of time wouldn't allow them to wait for the glad sunshine to come.

So, after comparing situations, we concluded we had much the better, and good-humoredly pocketing complaint we waited patiently till the sun thought fit to give us the light of his countenance. 


\section{An Unexpected Treat}

Who comes here? My doe?

-MerRY Wives.

ON one of our evenings in the wilderness we had a quiet spell for a few hours, and my guide and I started out moose calling. We pushed our canoe lightly and very cautiously up the inlet of the little lake on which we were camped, stopping frequently to listen, while we peered with expectant eyes into every bunch of alders, every clump of young pines, hoping against hope that we might see a moose "coming to water." It was about five o'clock in the afternoon. The air was still, not a breath was stirring, and the scenery along the brook was clothed in beauty beyond the reach of poet's pen or painter's art. The brown and green tints of the frosted and unfrosted ferns; the. tufts of waving grasses with their blades tipped with yellow; the alders just beginning to put on their autumn brown; the red maple, the yellow birch, the dark green pines, the stately juniper, the sad cypress -all mirrored in the tawny stream that flowed lazily beneath, without a ripple to disturb their sembled beauty or a murmur to interrupt the reigning silence. 
Silence? Yes! Nature seemed to be up to her neck in the depths of the hush. The guide now shored our canoe on a pine root to anchor it, and then took up his birch-bark horn and gave the three calls of the cow moose. First, the short, tremulous wail; then the more urgent and commanding one, and, lastly, the long resonant, loving, coaxing, imploring appeal, which no bull-moose with any bowels of compassion can resist. To produce this call the guide winds the horn around in continued circles, the motion giving the sound, that trembling, undulating effect which the genuine article always has.

Immediately after the call we heard a branch break in the woods to the right of us, perhaps a hundred yards away. I took up my field-glass and watched until I saw a couple of bewitching eyes, a pair of ears erect and vigilant, and the peculiarly graceful neck which I knew could belong only to the doe deer. She stood between two cedars and for awhile watched us intently, then stole carefully up the stream to where it turned sharp to the left and where a bank corered with marsh grass made a pretty foreground for the picture. Here she planted herself, rigid, with nostrils dilated, ears standing straight up, eyes fixed on us, and with every other indication that we were the only target that occupied her attention and curiosity. The guide gave the moose calls every few minutes and they could be heard miles away, yet there she stood, 


\section{AN UNEXPECTED TREAT}

"a thing of beauty" that charmed our eyes and raptured our conceit.

The day waned, the sun dropped behind the hills, twilight came and went, yet there she stood, motionless, entranced, and silhouetted against the erening sky like a graceful statue. Her eyes were still fastened on us, and when the cloak of night shut us from her sight her curiosity seemed to become uncontrollable. We heard her cross the brook softly, then steal down the left bank, picking her way daintily behind the alders and cedar trees until she was abreast of us. Then she stopped, and in the silence we imagined her letting loose her wild inquisitiveness: "Who can these mortals be? Poor things! How can they sit so long on the water and keep so still? What do they want here anyway? And where did that heavenly music come from?"

Perhaps she thought all this if she did not speak it. Then she stepped out in the open and came so close to the canoe that we could almost have hit her with a paddle. Did we shoot? No, sir! No thought had we of killing the soft-eyed, unsuspicious creature whose beauty and grace of form and pose had, for an hour, regaled our sense with such an unexpected treat of loveliness. Venison? Why, we would have gone without the dainty dish for many a day rather than have had it through the foul murder of that gentle, gazelle-like doe of Chesuncook Lake. 


\section{Killing the Caribou}

Here's sport indeed !

-CyMbeline.

WE had been semi-prisoners for about three weeks, and wearied with rains and high winds which effectually prevented the successful hunting of big game in the location of our camp.

Early one morning in October my guide said to me "Suppose we go and try to find that dam." We had heard a great many stories about a dam at the head of the stream which forms the inlet to our little lake, but were inclined to think some of these stories Munchausenish. None of our guides had ever seen the dam and had only hearsay for its location and distance. One maintained it was but five miles away; another six, and the third vowed it was a good eight miles off; besides, there are two branches to the stream, and no one knew on which of them the dam was placed. So the guide and I started in light hunting order, with a few bouillon capsules which were to serve us for dinner and supper, and possibly breakfast, if we shouldn't get back that night. We found a spotted path through the woods that led to an old tote-road up which we went splashing through the 


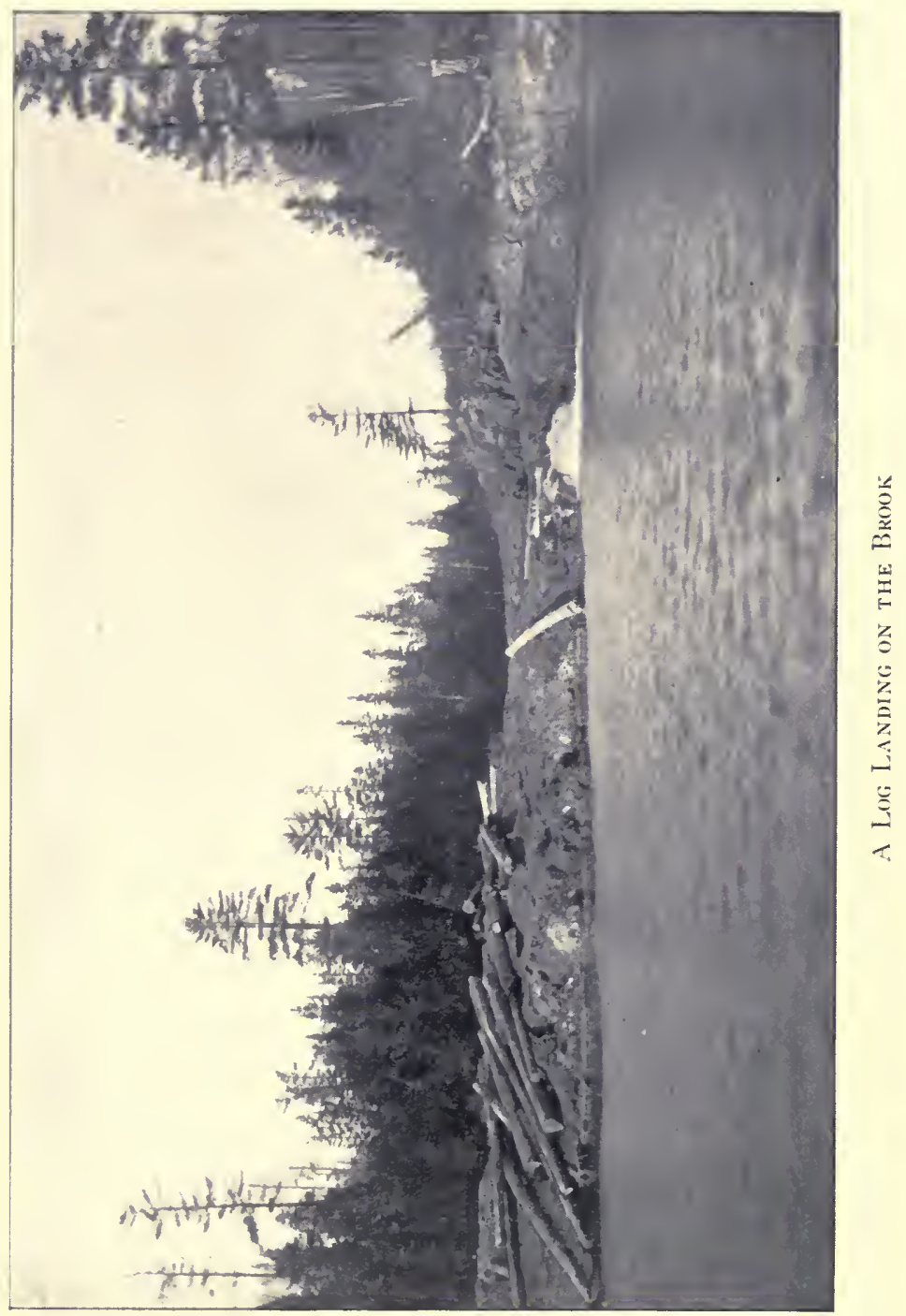





\section{KILLING THE CARIBOU}

water accumulated by weeks of rain; up to our very knees in mud sometimes, slipping, falling and stumbling over cedar roots, climbing over and under windfalls, until we reached an old lumber camp, which the guide thought it his duty to investigate. No Maine guide can pass an old camp for the first time without taking a look in to see if anything has been left that he can make use of. Before he reached the buildings three deer, one of them a big buck, jumped out. of some raspberry bushes and bounded away over the creek and into the woods beyond.

I started for them and stalked them for nearly an hour, until I came within shooting distance of the does; but although I heard the buck I could not get my eyes upon him, and the does I did not want; so I returned to the road. We now had a journey of three and a half miles over a road probably as bad as could be found anywhere; that is, if mud, water, alders, alder roots, cedar roots, windfalls and slippery rocks could make it so. There's an end to all things, however, and the road finally led us to a landing on the brook where a large number of logs were left high and dry from the last drive. Some of them, in fact, looked as if they had been there for years. There were probably half a million feet in and near this spot. We crossed the brook and found a logging road which we followed for a mile or more, but saw no signs of a dam. We heard an occasional deer crack- 
ing a dry limb in the dense wood or thicket of small pines which bordered the roadway on either side, but could not get a sight of him. Here the guide said we had better turn back, as we were going in the wrong direction; but I proposed walking, at any rate half a mile further, and probably we might find something worth shooting at. We made one turn in the road when we heard a branch break in front of us. We stopped to listen, and soon a calf caribou came out from the right hand side.

It looked up and down, saw us, then moved into the forest which was here open and filled with stunted spruce trees, growing in a thick bed of moss. The calf was followed a minute later by a cow. The guide whispered, "Now look out for horns!" Then another cow came out and crossed the road followed by a sight I shall never forget. A pair of monster antlers pushed slowly out into the road, and then came the head and neck of a caribou bull. A second later and the animal came into full view, as grand a specimen of his tribe as the sun ever shone upon.

The guide whispered, "Hit him in the shoulder; be steady and sure." And I was sure, for when I fired my 45-90 rifle, the caribou dropped in his tracks almost at the same instant. He hadn't moved an inch after being hit. The ball had passed through his left shoulder and out at the neck. We soon covered the hundred yards or more of distance which separated us 


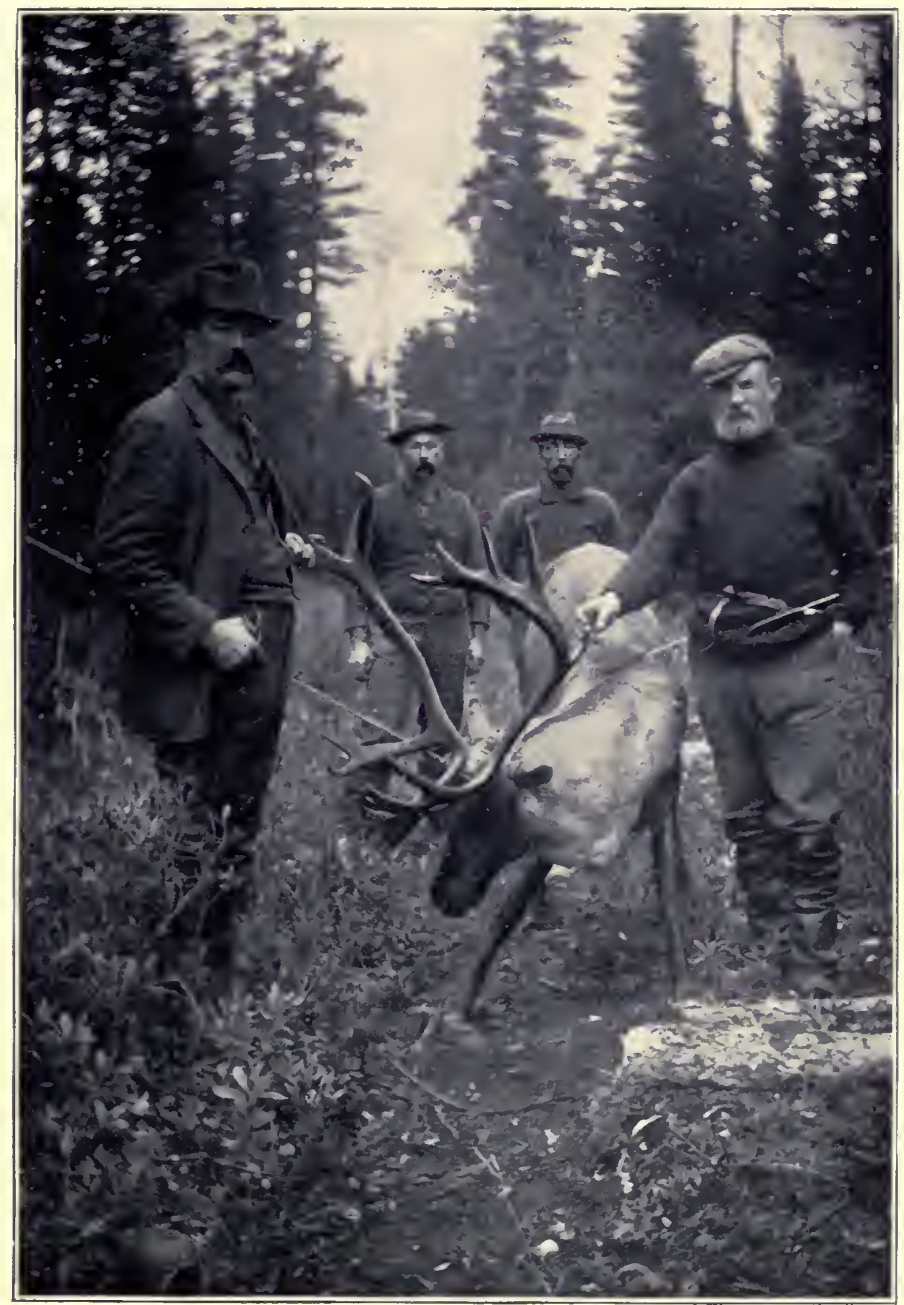

His Lordship; as Graxd a Specimex as tile Sux Ever SHONE UPON 



\section{KILLING THE CARIBOU}

from his lordship, whom we found down on his knees unable to rise. And then a battle royal started between the guide and the bull. The guide wanted to finish him with the back of the axe, and in order to do so he would angle around him, trying to get in a blow on the forehead. The caribou, however, although unable to raise himself to his feet, could and did swing his great head and antlers around in every direction with vicious and lightning-like quickness. Had he caught the guide ivith his antlers it would have been a sorry day for that personage. Another shot from my rifle, however, settled the matter. To keep the caribou in good shape we elevated his head and shoulders upon some skids that were in the road, and then tramped back to our camp, a walk of fully six miles. Next day our three guides with my son and myself went back, taking a camera with us, and although the morning was rainy and squally we obtained a fairly good picture of him. As he was frozen pretty stiff, the men raised him up on his feet and fasiened a rope, from each antler to a couple of trees, one on either side of the road. These held up his head and steadied his carcass so that my son was enabled to photograph him in a standing position.

The guides skinned him, but took off his head unskinned. The next day, in order to incur no risk of having the head spoiled by the wet weather or careless skinning, I sent a guide with it to Greenville, a 
three days' journey there and back. The bull was fourteen years old. The antlers are thirty-two inches long from the base of skull to the tips, and have thirteen points on each side. The taxidermist to whom the head was sent said it was the finest he had seen and the largest, from that locality, of which he had any record.

On the night of our caribou victory, although very tired and badly used up with our frightfully hard walk, neither the guide nor myself slept much. The big animal would haunt our sleep. We could see him almost every minute of the night; and even now the memory of the scene is fresh and vivid in my mind and doubtless will be for many a moon to come. 


\section{More of the Moose}

The Paragon of Animals. - HamLet.

ON the morning of the caribou hunt, we left the old bull lying in the road, and about eleven o'clock tramped back upon our tracks to prosecute our search for the dam which we had originally started out to find. Upon reaching the brook we followed it upwards some distance, until the guide, who was quite "done up," said he would make a fire and boil some hot water in a tin dipper for my dinner. I decided, however, to push on until I found that dam, telling him to stay where he was until my return.

The stream here was choked up with cut logs, which made it nice and easy walking, or easy jumping, from one to another. Twenty minutes of this sort of travel and I reached the long-looked-for dam. Climbing on top of it my eye caught the view of as lovely a spot for big game to feed in as could well be imagined. The water had been drawn off during the late spring, and a luxurious growth of swale grass, cranberry bushes, and young alder shoots, had sprung up in wild and wanton profusion.

I sat down on the dam and let my senses wallow 
in the sight. A stiff breeze was blowing, swaying the tall grasses into waves of graceful motion and bringing to my ear a gentle rustling sound-a twittering pianissimo, as it were, in one of Nature's pastorales, and one which all lovers of her rural melodies would have recognized and appreciated.

After iny fancy had played awhile it ran up against the thought: "What a tempting sanctuary is this for big game! Surely it won't be long without its antlered heads and arched necks." Instinctively I crept behind some bushes and watched and waited. Fifteen or twenty minutes passed without my expectations being fulfilled. Then I thought of my tin cup of bouillon and, fearing it would be spoiled, reluctantly left the enticing spot and traveled back over the logs to where the guide was waiting for me.

After drinking my bouillon I told the guide how near the dam was and what an attractive spot for game it must be; then I directed him to take my rifle and go up and look at some moose tracks which I had found, and I would boil another cup of water for his dinner while he was gone. The fire had burned down low. I put on more wood and sat and watched the roaring blaze, and whistled, while supreme contentment oozed out of me from every pore. My reverie lasted till broken by the guide who rushed in with hardly enough wind left to shape his words. He told me that just as he got to the dam a young bull-moose 


\section{MORE OF THE MOOSE}

and a monstrously big cow-moose had come out of the woods and were feeding in the open, close to the dam. We jumped like gymnasts across the logs and made some leaps that might have caused the kangaroo to blush and hide her head in her pouch.

As we approached the dam our steps grew cautious and when we reached it we peered over its edge and in the open space beyond. The bull was not in sight and the cow was more than five hundred yards away. No doubt they had scented the smoke from our fire, although the wind was almost directly in our favor. But we soon saw that the cow was uneasy and suspicious. She would stop her feeding, raise her mane, lift her head in the air, holding it there for a minute or so, and then resume her feeding. After repeating this program three times she gave a call that was quickly answered by the bull. A moment later he rushed out of the woods, at the back and to the right of her, while she ran to meet him. Then they wheeled about, threw up their great heads, and with dilating nostrils both sniffed the suspicious scent which had alarmed the cow so much. They were at this moment fully six to seven hundred yards off. Every moment seemed to increase their alarm and it was erident they would soon dash for the woods.

I said to the guide: "What do you think? Can I down that bull at this distance?"

"I don't think you can, but there's no telling what 
a $45-90$ rifle can do. If you're going to try it you'd better begin. They'll soon be off."

I decided to try the shot, and from under the edge of the dam I aimed for the bull's shoulder and fired. My shot was a clean miss. Then we saw a scene plainly illustrating the amount of human nature that underlies the instinct of the moose. As the report of the rifle rang out and echoed around the edges of the forest encircling the open space, the cow-moose ran here and there in every direction. Fear seemed to have dethroned her courage and prudence. But the bull stood still, rigid, erect, his mane up, while every hair on his body bristled defiance.

I fired cartridge No. 2, making another miss. Then came a repetition of the scene just described, the bull standing still as ever. I reasoned that the strong, quartering wind to the right was deflecting the bullets; so I aimed a little more to the left the third time and fired.

And then followed a strange sight. The bullet had reached the bull and he started with a rush and a crash. like a locomotive off the rails. Away he went, straight for the woods to the left. The guide and I then sprang upon the top of the dam and watched the cow who was still running about in the open, and thoroughly panic-struck. A couple of minutes elapsed and then the wounded bull ran back from his stronghold of timber to get the cow away from danger. 


\section{MORE OF THE MOOSE}

This gave me a chance to fire three more shots at him. While he was circling around the cow and trying to lead her into the safety of the woods, he seemed to say: "You can shoot at me if you like and kill me if you can, but I'll save my frau or perish in the attempt!"

And just as soon as he had her headed and started right, then he got away also, both entering the woods to the left.

Then the question came: What shall we do? The guide said: "Let's go back to camp and give him a chance to lie down. If he's mortally wounded we'll find him, but I fear you've given him only a flesh wound." We stopped at our fire for the guide to drink his bouillon and then commenced our eight-mile journey to our tent. On the road down, and before we reached the logging camp where we had started the buck deer and the two does the day before, I crept along very cautiously, hoping to catch a sight of the big buck. The road that led by the old camp had a path in which were several long logs leading lengthwise from the road right to the camp, and walking on these logs with rubber boots made no noise at all. Suddenly I came upon six deer feeding in and around a lot of raspberry bushes. Four of them were so bunched that I could have placed a bullet which would have gone, possibly, through the whole four, certainly through three of them. But they were all 
does; the buck was not there and I stole back to the tote-road without even alarming them.

It was dark when we reached camp, and we were tired; yet the excitement of the day had been so great that, wearied as we were, we could not sleep. The caribou and the moose and the six deer kept marching through our minds in company with the queries: "Will we find the moose? Is he killed? Will anything get at the caribou during the night and mutilate him?" In our mind's eye we saw the old fellow dropping in his tracks; and again we saw the bullmoose rushing from the woods to coax the wife of his bosom back from the reach of bullets and into a place of safety.

Thus the day's adventures would be vividly reënacted till daylight broke. Then ready and eager to solve our caribou queries, the guides, my son and myself breakfasted, shouldered camera, axes, rifles and ropes and started off with the intention first to photograph and skin the caribou and secure his head, and then to trail the wounded moose. It was half-past one when we reached the dam, and in a few minutes we found the trail of the bull by discovering a pool of blood in the swale grass and another considerable pool on the edge of the woods. After that the trails of the cow-moose and the bull were so intertwined that it was hard to unravel them. But there were five of us and each would discover a trace every minute or two; some- 


\section{MORE OF THE MOOSE}

times a splash of blood on the side of a tree, or a drop on a leaf, or a streak of it on some deadfall the wounded moose had stepped over. At one place he had passed between two trees, evidently a tight fit, as it showed the blood from the left hip, where he was struck, down his leg as far as the knee. At another place he had stopped and quite a circle of blood was formed. But nowhere was there any sign that he had lain down. Nowhere was there blood enough to show that he had been mortally hit. We followed his trail for over two hours and then reluctantly concluded that our moose would live and prosper perhaps for many a year to come, as he would be duly careful in the future to keep as far away from the range of a rifle as his haunts and habits would permit. At all events, he would never again feed in a meadow in daylight during the open season-for a moose needs to be shot at but once to make him forever after the most cautious animal that roams the wild woods. 


\section{$A$ Lost Man and a Wounded Moose}

I have lost my way.

-Antony and Cleopatra.

IT is the unexpected that always happens in hunting. When you most desire and look for your game, then is the time you don't see it; and when and where you don't look for it, then and there you are apt to run against it.

My guides had told me marvellous tales of the hunting opportunities that flourished around a certain pond or small lake, a couple of days' journey from our camping ground. To find out whether these tales were true or not, I thought it worth while to go there, especially as one of the guides had spent the previous winter in a lumber camp near by, and was familiar, or ought to have been, with the country. There was a very large bog, five miles long and about a mile broad, which was a favorite haunt of the caribou, moose and deer, and they found in it enough rich food for sustenance without resorting to any other locality.

Very pretty and promising all this, but there is no rose without a thorn, and this rose of ours had one in the shape of a goose-a goose of a sportsman who was camped on a stream some two miles away from the 


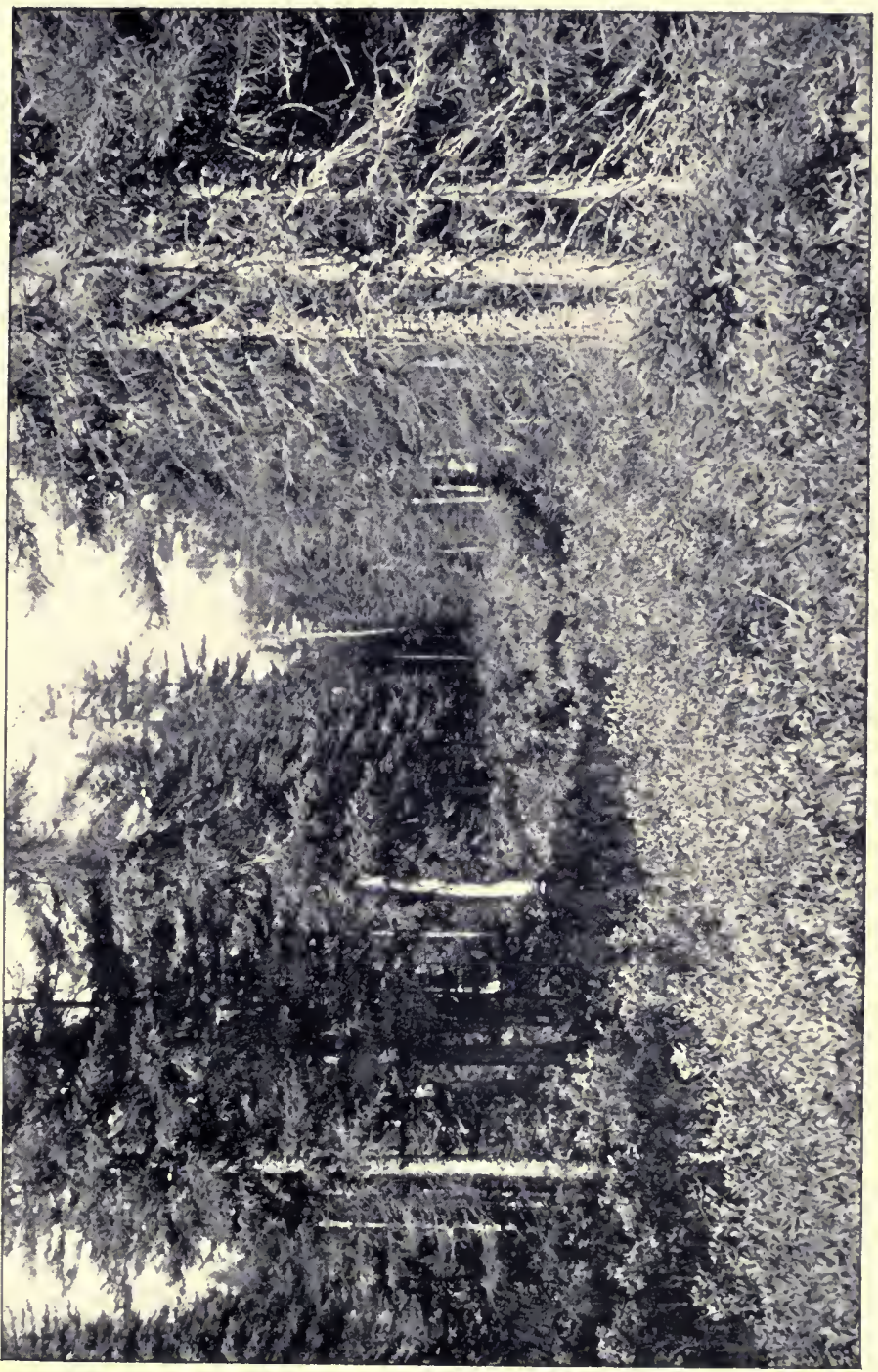





\section{A WOUNDED MOOSE}

pond. The goose delighted in firing a rifle that burned one hundred grains of powder behind a fifty-calibre bullet, and enjoyed himself hugely in loading up his miniature cannon and banging away at red squirrels, partridges and rabbits. He would leave his camp in the morning, walk to the pond, and make the woods ring for miles around with the noise of his rifle.

The unwritten law of Maine in regard to the shooting-rights on ponds or small lakes is that the sportsman who first puts a canoe upon them is safe from intrusion on the part of any other sportsman. Acting upon this hint we determined to paddle up a stream as far as we could, then carry our canoe to the pond and take possession, thus shutting out our noisy friend. So at four o'clock one morning our strongest guide started with his canoe on his back, carried it for a distance of two miles, placed it on the pond and returned to camp for breakfast. Then after our morning meal I started with another guide and walked to the pond, loaded only with a tin cup, an axe and a rifle. We reached the pond at about half-past seven and got into the canoe, but at the very first dip of our paddle we heard the boom of the 50-100 rifle fired by our goose who was cracking a way at the red squirrels on the other side of the pond. This was not a promising state of affairs for us-big game, as a rule don't like cannonading, nor a neighborhood that indulges in it. A few minutes after the noise of the shot and its 
echoes were sobered into silence, we saw a pair of deer two hundred yards away. My guide suggested that I try a shot at them, saying it would be a good idea, even if I missed the deer, for it would let the goose know that there was a canoe on the pond, that the pond was mortgaged and he had better find some other spot for his cannonading. The deer, however, were in an awkward place to be shot at with effect. However, I did shoot and missed. They wheeled like a flash and bounded into the woods. The sound of the shot reached the goose with the 50-100 rifle who stepped out into the open, saw us, and started back for his camp.

We now paddled to the other side of the pond and as the sun was coming out warm we left our coats and vests in the canoe, took with us a tin cup and four bouillon capsules and left, feeling sure that the goose's cannonading had killed all our chances of seeing any more game that day. We left the canoe exactly at eight o'clock (I know, for I looked at my watch on starting). Not more than five minutes later my foot stumbled in the bog. Recovering my foothold and looking up I saw a sight that startled me. Not a hundred yards away a great bull-moose, with widespreading antlers and dilated nostrils stood looking straight at me from between two trees. The place where he was standing was one where a man would least expect to see him, because, by all rules of pru- 
dence and safe moose conduct, the noise of the late rifle shots should by this time have driven him miles away from this locality. It appears it did not. And what did I do under the circumstances? Well, precisely what any other man would have done. Up went my rifle and without sighting or even an attempt to take careful aim, I blazed away. And the moose? Ah! Like a ghost he came and like a ghost he disappeared. The guide-a French Canadian-said: "Vat you shoot at?" "A bull-moose," I replied. "Didn't you see him?" "No, I no see him!" "Well," I said, "we'll take up his trail and see if he's hit." "You no hit him," he answered disdainfully.

We tramped around trying to find his tracks but without much hope of seeing them or the tell-tale drops of blood; for the bog was soft and the feet of the moose thus left no mark as he ran, and the red moss that covered the bog prevented the blood-if there was any-from showing on it. We finally worked out of the bog and took the ground leading up to a ridge. Making careful search as we walked, we found, at last, a drop of fresh, hot blood on a leaf; then a little further on, a pool of blood that would have filled a bucket. This blood was mixed with the pink tissue of the lungs, showing plainly that the bullet had gone through that organ of his anatomy. I now proposed to spot the trees so that we could find the place again and then go back to camp, giving the 
moose a chance to lie down and bleed to death. My French Canadian, with a whiff of his old clay pipe, gave it as his opinion that the bull was mortally wounded, that we would find him in a few minutes, and advised that we follow him at once. We did so, finding no difficulty whatever in tracking him as his trail was almost a continuous stream of blood, excepting when his wound had apparently become clogged with a piece of the pink tissue, and then for a few yards we would lose his trail; but only for a few yards, for soon the gushing blood would spurt its passage through and form another pool. And thus we followed on, over ridges and through swamps and bogs, hoping soon to catch a sight of our expected prize. Sometimes we would strike a place where the bull had stopped to listen; and again where he had gone around a windfall, showing he was hard hit, if not mortally wounded. How did we reach these conclusions? Simply enough. The hunter-if he be anything of a detective, which he should be-on seeing, as we saw, a plainly drawn half circle of blood, would say: "Ilere he stopped and turned half around to listen." In the second instance, if he had not been hard hit he would have gone over the windfall and not around it. Once we saw where he had leaned against a tree, either to rest or listen, or both, but nowhere was there any evidence that he had lain down. Twice in our pursuit we heard him crashing through the brush 


\section{A WOUNDED MOOSE}

ahead of us, but at neither time were we fortunate enough to catch a glimpse of him.

Our brain befuddled with the chase,

We took no note of time or space;

and before we were aware of it the morning hours had gone and we found ourselves on the borders of another lake, miles away from our canoe and our camp.

About three o'clock in the afternoon we built a little fire, heated some water in our tin cup and boiled a bouillon capsule for each of us, which we drank. Then came the question: "What shall we do now?" The guide said we were about four and a half miles from the canoe, and that in following the twists and turns of the wounded bull we had covered a distance of about eighteen miles. His advice was that we should start at once for our canoe-after spotting the trees with the axe to enable us to take up the bull's trail again and track him to his deathbed. So at half-past three we started back, the guide assuring me that he knew the way perfectly well. Maybe he did, but coming events left a shadow of doubt on my mind. He first led through an alder swamp that only needed a Bengal tiger or two to rival an Indian jungle. Lathered with perspiration we finally got through this and faced a high ridge covered with numerous windfalls. After scaling the ridge and getting down 
on the other side of it we found ourselves in a dense cedar swamp, wandering here and there and perspiring at every pore with the labor of climbing over and under logs and jumping windfalls. Then came the pleasant conviction: "We are lost!"

The weather had turned cold and suggested that we lose no time in getting some wood together and starting a fire. We were certainly in an unpleasant predicament; without coat or vest, or blanket, or tent, with nothing to eat and nothing to drink. Could we have found water our remaining two bouillon capsules would have made us a good supper; but there was no water and consequently no supper. The best and only thing to do now, I did. I pulled off my hip rubber boots, intending to use them for a pillow, dried my few clothes, wet from perspiration, and kept close to the fire to avoid catching cold from the bare ground and freezing air. My purpose was not to sleep, but keep awake. "Tired Nature," however, would not be denied her "sweet restorer," and soon I was in a slumber that lasted till eleven o'clock. Then I awoke to find the cold intense. Piling more wood on the fire, I threw myself again on Mother Earth's bosom and slept till two, when the frost, settling on my face like sharp needles, aroused me. Again I replenished the fire and again slept till five. Then I awoke and just in time to catcl Aurora at her morning task of decorating the eastern sky. And I yatched her with the 


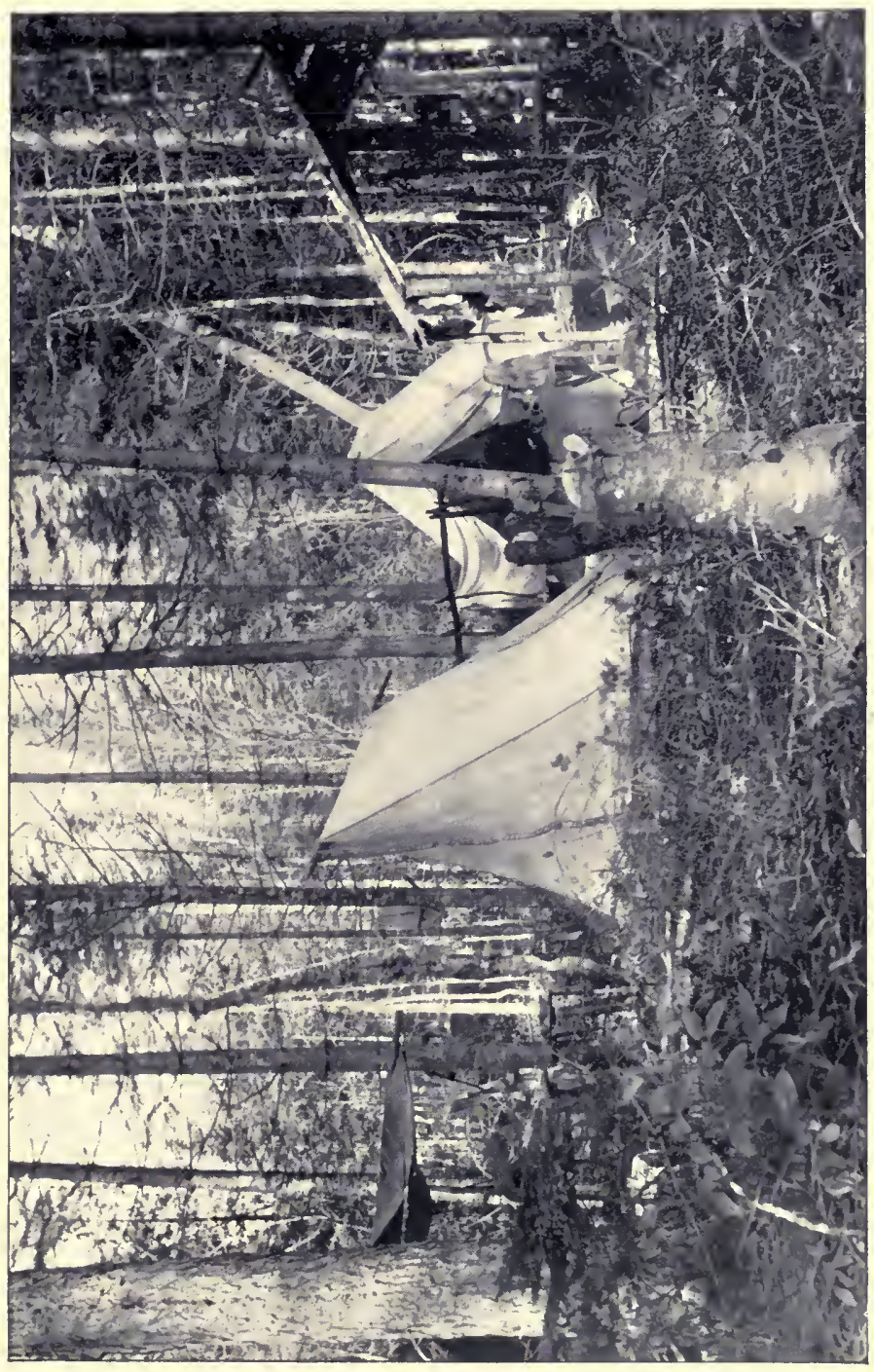

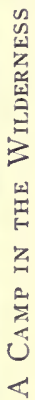





\section{A WOUNDED MOOSE}

greatest satisfaction, for never in my recollection was daylight so welcome to me.

Our search now was for water, but we succeeded in finding none. We did find, however, a thin sheet of ice under an upturned cedar root. This we broke and melted in our tin cup over the fire and then cooked our capsules in it. Such was our breakfast, and I am rather sure the Roman, glutton, Lucullus never experienced greater satisfaction over one of his ten-thousand-dollar dinners than we did over that simple meal of bouillon.

After our breakfast we found a lumber road and followed it for about three miles to a great.marsh or meadow. Here we obtained our bearings, discovering that we were about five miles from camp, which we reached at eleven o'clock that forenoon, thankful and happy to see once more our white tent and the guide we had left behind, whose anxious face told plainly of his alarm at our absence. He had been firing shots at frequent intervals during the night, but the distance between us prevented our hearing them. We had been tramping around an ever-widening circle, until night compelled us to stop. Mry French Canadian guide, who was one of the "I-know-it-all" men, had nothing to say in extenuation but this: "I don't compre' how it all did happen. I did know ze way sure, and then I didn't. I feel much sorry, but ze nex' time I go by ze compass, not by ze knows how." 


\section{A Capricious Beast}

You are a pair of strange ones.

-Coriolaxus.

TuE moose is a strange animal in many respects. In his outside make-up this strangeness is strongly marked by his large, truncated antlers, his " bell"-a tuft of nerves, muscles and hair, hanging from his neck-his great mane, his high shoulders, his retreating hips and his stumpy bit of a tail. His "inside," or, so to speak, his mental make-up is quite as strange. $\mathrm{He}$ is full of suspicion, ever on the alert for danger, and governed by a disposition stuffed with caprice. What you most expect him to do, when you are after him, he is apt not to do at all; and what your experience tells you he will never do, he often astonishes you by doing in the most provoling manner. He is an enormous eater, a great traveller, and something of a Lothario in his relish for courtship. He usually feeds in the early morning, rests during the day, and does all his travelling and courting at night; although the whim sometimes seizes him to venture a visit to his sweetheart in the daytime; but it is a perilous venture and one which he often has cause to regret. 


\section{A CAPRICIOUS BEAST}

Like the rest of the deer tribe the moose is afraid of fire and smoke; and yet I have known a bull, when wild with passion, to charge into a camp where a log fire was burning and a French Canadian cook was busy washing his dishes in front of it.

The sudden entrance of the bull created considerable excitement and for awhile he made it warm enough in that camp to dispense with any other sort of fire. Without any ceremony, further than bending his head, he went for the cook and chased him out to the water, where the astonished dishwasher jumped into a canoe and paddled hastily from the shore, shouting to the irate moose: "Sacre, mon dieu! It is a meestake-I did not make ze call!"

During the mating season there is no denying the heroism of the bull-moose, nor the courageous care with which he watches over the welfare of his mistress. But when his passion is on the wane, his courage, like that of Bob Acres, oozes out and leaves him with the heart of a chicken. At these times, if he happens to be out on a promenade with his lady, he politely asks her to walk in front of him. Of course such a request would be commendable were it not for the ugly suspicion that something else than politeness lurks behind it. He is always brimming with caution, and who can say that he is not aware of the hundred-dollar fine and four-months' imprisonment that await the slayer of his mistress? If he is, then, as "self-preser- 
vation is the first law of nature," his instinct may possibly tell him that the surest way to preserve himself is to walk behind his lady-love. There is no doubt that his bravery, at times, resembles that of the pigeon-hearted Falstaff; and, as life is probably as precious to him as it was to the fat knight, perhaps he is excusable in taking the same care of it.

If two or more bulls meet during the mating season, there is likely to be trouble, and much of it, especially if one of their lady-loves should chance to be in the neighborhood. Here is an instance, however, where they smothered their jealousy-a proof of what I have said about their capriciousness in not doing what you expect them to do. A young man who acted as cook for a party, of which I was one, had a strong desire to learn the art of moose-calling. One night the youth went out with a sportsman, in the absence of the regular moose-caller, for the purpose of trying his hand at it. After three or four calls he was delighted with an answer. He waited a little while and then heard the bull coming down through the alders that fringed the stream and cautiously steal up and down through them. Now and then the youth could hear him strike his antlers against the alders and break a branch, but further than this the hopes of the young moose-caller were not gratified. All his piping failed to coax the bull to show himself. Disappointed, disheartened, weary, and shivering with cold, the sportsman and his young 


\section{A CAPRICIOUS BEAST}

caller returned to their camp and slept until daylight. They were soon up and paddling their canoe to the place of last night's seance. They approached the spot cautiously and saw plenty of moose tracks along the water's edge, but nothing of the animals that made them. The youth, however, took up his moose horn, gave a call, and almost instantly came an answer, and with it a sight that made his eyes bulge with wonder. A rush, and a cracking through the alders, and then, not one, but three big bulls stepped quickly into view, gazing inquisitively at the canoe and its contents. The sportsman brought his rifle to his shoulder and picking out the biggest moose of the three for his aim, banged away at him, but-well, the youth declares that any man who couldn't hit one bull in a three-ply bunch, in broad daylight, and not more than forty yards away, should swap his rifle for a gatling gun. The trio had escaped, unharmed.

Now the point to which I wish to draw attention is not the somewhat queer anomaly that a "sport" should be guilty of missing the big head of a bull at forty yards, but to the fact that three male moose were bunched together in the mating season, and in a sociable way, with

No leer of battle in their eye ;

No clash of antlers in their thought.

Speaking of the bull-moose's eccentricities, the cow, 
too, has hers, and they are no less marked. The senses of hearing and smell are believed to be keener in the moose tribe than in any other animal, and yet I have stood within a few feet of a cow-moose, seemingly without her being aware of it. She was coming toward me at the time, with her head down, and in a careless sort of way that betokened unconsciousness of danger. I stepped behind a tree. She stopped and listened, drawing in volumes of air through her big nostrils. I waited for a while and then pushed out from my hiding-place and into her full view. She showed neither fright nor surprise, but eyed me inquisitively for a minute or two and then turned her steps leisurely into the woods. Such demure equanimity, however, is but an intermittent characteristic. In the mating season all her artless composure seems to desert her, and then, like her lord and master, with nostrils dilated and ears erect, she is ever on the qui vive for danger.

The instinct of the moose approaches closely to human reason-a fact which may be illustrated by an incident that occurred during a violent October snowstorm. A pair of moose were found standing in a clearing near an old lumber camp, and by their tracks it was noticed they had not stirred from the vicinity of the camp since the storm started, on the day previous. Evidently they had been afraid of the falling trees in the woods, which, from the weight of the 


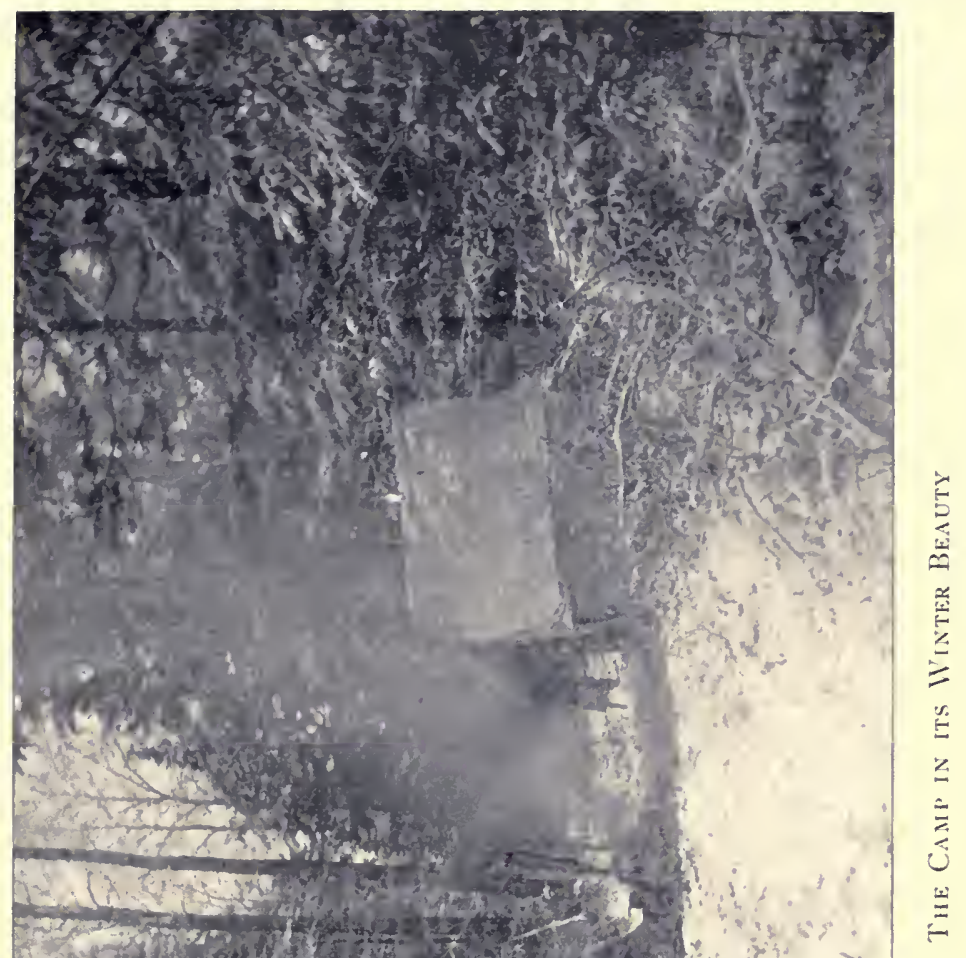





\section{A CAPRICIOUS BEAST}

snow upon them, were crashing and breaking in every direction.

A bull-moose in a passion is not a pleasant fellow to run against, as a lumber operator once discovered. He was taking a gang of men into the woods and jogging along a mile or so ahead of them, with an axe on his shoulder. Hearing a slight noise he looked up, and directly in front of him stood an angry bull. Whether the red shirt the lumberman wore had anything to do with the moose's anger I can't say; but whether it had or not, the bull made a vicious rush for him, giving him barely time to dodge behind a tree. This place of refuge, however, didn't seem to satisfy the lumberman. The bull became so fierce and determined in his attacks that the man decided the top of the tree, and not the bottom, was the only proper place. It required a little finessing to carry out his decision, but he finally succeeded in climbing beyond the reach of the bull who stood at the bottom keeping a sharp eye lest his contemplated victim should escape. He kept up his sentry work until the lumberman's gang came along; then, at the sight of them, his bullship turned sullenly around and retreated into the woods.

They are sometimes very hard to kill, and then again are killed with more ease than a small deer. A moose was hit at close range by a 40-82 ball, which tore his liver and lungs into fragments, but off he 
went as if he hadn't been touched. A second ball pierced his heart and yet he traveled over sixty yards before he fell.

Yes, they are the most uncertain animal to hunt and kill that can be found, and it is partly on account of this uncertainty that the hunting of them is so exciting and captivating. The unexpected is always happening in moose territory, and therefore your expectancy is constantly kept on a wire edge. You look at their tracks-which, maybe, are very fresh, or, perhaps, very old-and say to yourself, "What if he would show himself behind that bend in the road, or on that bit of open bog, or in that bunch of alders, or standing in among those lily-pads?" Then you think how many hours it was since he passed, and debate in your mind whether it was in the night or early in the morning. You are not sure of anything that relates to him. The water where he planted his big feet as he walked in this muddy spot is roily, but it doesn't follow that the fellow did not make the tracks last night, instead of this morning, as some water takes longer to settle and clear than other. You cannot be exactly certain of the hour that he passed, even by his tracks. I am speaking now of really "fresh" tracks and signs, so called, which keep the hunter continually keyed up to the sharpest pitch of nerrous tension, that is, if he is really hunting in earnest, and not killing time 


\section{A CAPRICIOUS BEAST}

in examining signs; or if he be not too lazy to get up in the morning when the frost is sharp and keen and he thinks it too cold to leave his warm and snug bed, to say nothing about going miles away and sitting for hours shivering in a canoe and waiting for an answer to his call. All this he should get used toand must, if he aspires to bear the hunter's "blushing honors thick upon him." 


\section{My First Bull-Moose}

But if thou needs will hunt, be ruled by me.

-Vexus Axd Adoxis.

I HAVE been asked to narrate the killing of my first bull-moose. I will try to do so, yet it is no easy task. Others with a like experience in moose killing, I think, will agree with me when I say that the anxiety, the exposure, the suspense, a hunter must undergo, and the cunning skill and perseverance he must use in luring the suspicious creature to the water and then killing him are hardly within the power of an ordinary pen to describe. I have known a hunter, who was said to be an expert, to spend nine nights and as many mornings before he could coax his bull to come from shelter; and when he did show himself, a rifle shot rang out on the air, of course, but with what result? A dead moose lay there-not a "giant of the Maine woods" as the hunter had so fondly hoped-but only a four-year-old "spike horn."

The difficulties surrounding my first bull-moose adventure, while not so great as those which this particular hunter had encountered, were quite greai enough to satisfy my appetite for difficulties.

And now for a bit of my own experience.

On a calm, frosty night while the October moon 


\section{MY FIRST BULL-MOOSE}

was yet young, my guide and myself paddled noiselessly out of the lake, on which we were camped, and into the twisting and beautiful stretch of dead-water that feeds the lake and which is about two miles long. The guide took up his birch-bark horn and ran a little water through it, following up this preliminary by spitting vigorously first on the one side of the canoe and then on the other. I didn't then, nor do I now see the necessity for the expectorating part of his program, but I hear that all professional moose-callers invariably go through it and therefore I suppose it must be a necessary part of the performance. This prelude being over, the guide put the horn to his lips and gave the famous moose call so often described and yet never described. We sat listening to its tremulous notes quivering on the air and when they died away in the silence we waited impatiently for an answer. Our waiting was fruitless. Save the hooting of an owl or the splash of a muskrat, there came no sound to break the grave-like stillness. Again the guide gave the call and again we waited. Hark! a crackling of alders now greeted our ears. The sound came from a long distance up stream and told us that a creature of some sort was approaching. A little later we heard a crashing on our left, but no grunting, no barking to indicate that a bull-moose was anywhere in the neighborhood. We strained our ears for a sound that would give us a cue to the sort of animal 
that was breaking the bushes and whose tread was not heavy enough for a moose and yet too heavy for a deer. Then we heard a splash and then another. "They're in the water; we'll soon see what they are," said the guide. We pushed the canoe softly up the stream, but the creatures, whatever they were, had heard us and left the water. The stream was narrow, not more than twenty feet wide, with high alders on each bank, and on either side of us was some animal, we knew not what, that probably had its eyes and ears open for our every motion, watching us suspiciously as though we were freebooters and had no right to be filibustering in its domain.

The guide now whispered to me, "If they are moose, you will find the one on the right hand is the bull."

We could see nothing, yet we sat there for fully an hour straining our eyes through the darkness and opening our ears for a clue that would tell us at least what sort of creatures they were.

The night was getting colder and my teeth began to rattle like a pair of castanets. It was quite natural therefore that I should be anxious for our suspense to come to an end of some sort; and it did. With a snort-or, rather, two snorts-the animals bounded away, and in a twinkling both were gone.

They were deer, not moose as we had hoped. Disappointed, and chilled to the bone, we paddled sadly back to our camp and turned in, as it seemed unlikely 
we should have further use for moose-calling that night.

Next morning we were out at half-past four, but we received no answer to our calls. In the evening of the second day we went up the stream as early as five o'clock, running the nose of the canoe into a bunch of swale grass near to the mouth of an old lumber road. This night, like the last, was clear and very cold and the water was freezing in the shallow, quiet parts of the stream, making a turn of the canoe in some places a noisy performance. After the first call had echoed and reechoed around the ridges on our right and left, we were rejoiced to get an answer. At first it was only a smothered grunt; then followed a hoarse, well-defined bark that seemed to be miles away. Louder and louder and more frequent grew the barking as the bull came nearer-for bull it was -and it seemed as if each step of his approach was accompanied with a grunt or a bark. To our dismay he came down the very road of which we were nearly in front. When almost at its mouth, he stopped, listened for a moment and then moved up and down the banks, crashing and breaking the alders and listening at every step, as if to catch another whisper from his mistress. Yet he took the best of care not to show himself. In the meanwhile the guide was busy pawing the water with his birch-bark horn or letting some of it pour from the narrow end of the instru- 
ment. These manœuvres were intended to imitate the motions of the impatient cow and were expressly for the bull's information, telling him that his lady-love, whose voice he had heard and for whose embraces he was longing, was now feeding in the water on lilypads and almost under the nose of his majesty. But his majesty was cautious. He was most eager, of course, to meet his inamorata and have an embrace or two, but he was not disposed to let his eagerness get the better of his prudence. He evidently scented treachery in the air and was so shy that all the guide's ingenuity failed to coax him to come from out the alders and show himself. Though we could catch no glimpse of him, doubtless he had all the glimpses he wanted of us, and pipe as we might he was in no humor to dance to our music. So we left him, returned to camp and turned in, with our brain-pan brimming with visions of a bull-moose with an ounce of lead in his vitals.

The morning of the third day found us dressed and in the canoe. It was then three o'clock and as dark as Cimmerian pitch. A swift paddle to the head of the lake, then a silent push up the stream and our calling spot was reached. TVe gave our first call at four o'clock and then waited fifteen minutes for an answer which didn't come. Then we gave another series of calls and again waited. The guide now leaned towards me and whispered: "Listen! is that a 
moose or an owl 'way off there?" "Can't say yet," I replied; "it sounds a little like both." We then gave a third call, and after a rapt silence we again heard the unknown sound. We listened and distinctly lheard the breaking of a branch a long distance away. $\Lambda$ gain we strained our ears, and this time they were rewarded with a decided answer from a bull-moose. He was surely coming, but not with the tearing rush so characteristic of these fellows when they're on their way to their sweetheart. He was taking his own time and approaching very leisurely. Probably he felt sure of the fair one who had so lovingly called him and therefore there was no need of hurry. She could wait.

And now the day was breaking. Rosy tints were lighting up the sky and shimmering on the alders, the cranberry bushes and the hazels-all freshly clothed in a suit of night frost. It might have seemed to a casual observer that both the guide and myself were clothed in a like manner, for we sat there with a chatter of teeth and a shiver of limbs that our blankets, our overcoats, and our heavy gloves could not put a stop to. We kept perfectly still otherwise; fearing almost to breathe, lest it might create some sound that would reach the sharp ears of the bull. Yet at this critical time my teeth started up a fresh and vigorous chatter, which the guide's molars and incisors promptly took up, and with the liveliest sort of a staccato movement. Now, I am quite sure that if the 
bull had been within hearing and had an ear for music of that sort, our chatter duet must have been highly entertaining to him. But he either had no musical ear or was too far away to take in our duet, for he continued on his way through the alders at his former slow and dignified gait. At one time he stopped to reconnoitre. Then he passed up and down through the bushes, listened a moment to the guide's pawing of the water, cocked up his ears and suddenly came to the conclusion that he had been fooled. He at once let loose his disappointment with a roar of rage and revenge that might have been heard miles away. The bare thought of being tricked filled him with indignation and a strong desire to get away from such a treacherous spot. The guide kept quiet until the angry bull had gotten about a quarter of a mile away from the canoe. Then picking up his horn he gave a low, tremulous and loving call. The moose immediately wheeled about and walked back, answering the call between his steps, and in the most affectionate and apologetic tones. They spoke as plainly as the tongue of a moose knows how to speak: "Forgive me, darling; I've been fooled so often. I'll soon be with you, pet!" When he reached the alders he stopped for a minute, and the guide took advantage of that minute to imitate the sounds made by a feeding cow. They soon reached the alert ears of the bull and seemed to satisfy and fill him with the 


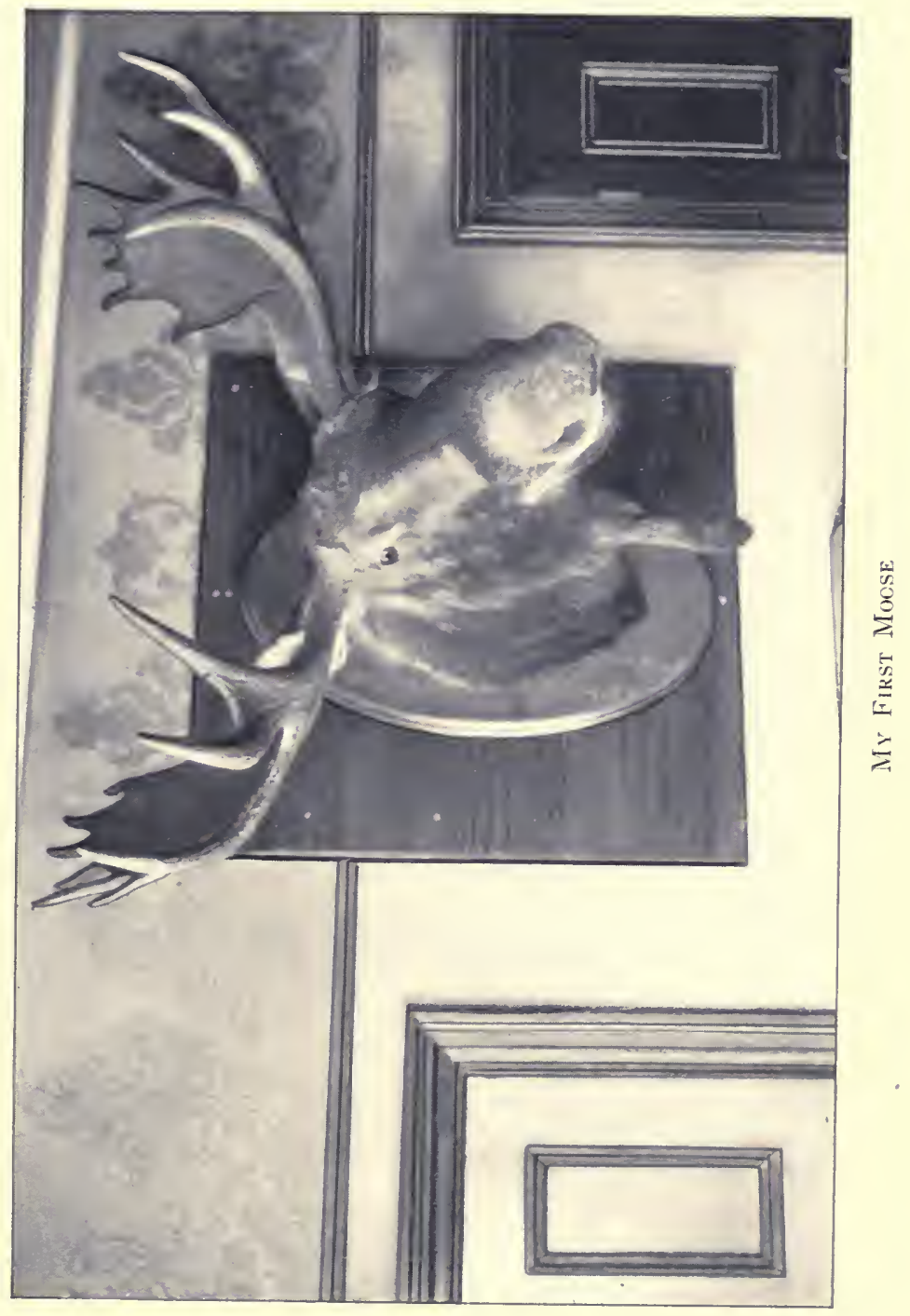



thought: "There's no mistake this time. Here she is!" I don't know whether he thought this or not, but certain it is that he plunged into the water and commenced wading down the stream, which at this place followed the land around a point that formed a long, narrow elbow. We first thought he would burst through the fringe of alders on the thinnest part of this elbow, and therefore pushed in our canoe. However, he passed that point, still wading in the water, and we were compelled to back out of this little cove and into the stream.

The guide now shoved the canoe directly towards him, as swiftly as he could, whispering to me "Be steady now! Don't lose him." Meanwhile I had my rifle to my shoulder, expecting each moment would give me my opportunity to use it. It was now daylight, exactly half-past five; the bull was coming down the stream and we were going up. My mind was full of what I expected would happen, and I was saying to myself "failure is impossible," when the canoe rounded a sharp point of the elbow, and behold, there stood his majesty! His head, topped by his grand antlers, was thrown proudly back, while his whole attitude was one of confident expectancy as he marched to meet his pseudo-mistress. He saw me and made a quick movement to the right, bringing his head sideways to me. This was my chance and I fired instantly, aiming at a point an inch or two 
below the base of his antlers. After the shot he whirled around, giving me a broadside chance which I was quick to take advantage of. The next instant a dead bull toppled over into the water. He hadn't moved a step after my first shot, and the whole performance was over in less than half a minute. The first ball had entered just below the ear, and this it was, no doubt, that caused him to whirl. It was in fact the fatal shot. The second one had penetrated his loins.

The guide now shoved the canoe up to the shore and we both got out and danced and jumped to warm ourselves. We also did a little dancing for joy at the sight of the great beast lying in the water, with the blades of his antlers showing one half above the surface of the stream. We forgot all about our exposure, our suspense, our loss of sleep, and our many disappointments, and with one loud hurra we paddled back to camp, and there, over the breakfast-table, we told to our companions how I killed my first bull-moose.

Was I proud? Well, rather;

No chit, in his first pair of breeches ;

No swain, in a "yes" from his loved one;

No spouter, with audience captured;

No General, with victory won -

ever felt prouder than did I, as I stood in the Wilds of Maine and over the prostrate carcass of that "Giant of the Northern Forests." 


\section{A Caribou Hunt}

How many goodly creatures are there here !

-THE TEMPEsT.

A BRIGHT morning in one September found me on my way for a caribou hunt in the pine woods of Maine. The train had reached Boston and I was about stepping from the sleeper when a sudden kink in my back warned me that there was trouble ahead for Thomas. In plainer words, I felt it in my bones, or rather muscles, that my bete noire, the lumbago, was about to pay me a visit. In one respect that wily disease resembles the rattle-snake - it doesn't use its fangs without warning; but it is very unlike the rattler in another respect; when its warning does come, its fangs are sure to come with it.

From Boston to Greenville, Maine, towards which we were traveling, is a ride of nine hours, and during that time the lumbago had been grinding its fangs into my lumbar regions and twisting my backbone till its owner's contour looked something like the letter $\mathrm{S}$.

On reaching Greenville I decided that I must adopt some heroic measure, and do it quickly, or the bottom would be knocked out of my caribou hunt. Expe- 
rience told me that exercise was the most effective physic for the complaint and I was not long in thinking of something that would give me plenty of it.

I asked the landlord of the hotel at which I stopped if he had a bicycle in the house. He said he had, but it was one of the female gender.

" All the better," I replied. "Let me have it."

How I mounted that bicycle I leave to the imagination of the reader; but if he has never seen a man with the lumbago, in the act of mounting the silent steed, his imagination will be of little use to him. To get on the saddle, usually the work of an instant, now consumed many of them, and if " the steed" had been a diamond frame, instead of the female sort, I can't say that I ever would have got there.

Once mounted I took a hard ride of a few miles, with plenty of stiff hills to climb. When I got back I was in a profuse perspiration. Then I sent for the village doctor; not that $I$ had more faith in a village doctor than any other sort, but because "any other sort" was out of the question. He came, bringing with him an electric battery and a big bottle of iodine. Then baring my back for operations he soon had the battery to work, and it played around my lumbar regions and kept up its tingling sensations for fifteen minutes. After this he painted my entire back with the iodine and left me with the assurance that I 


\section{A CARIBOU HUNT}

would soon feel the effect of his treatment; and I did-a little sooner and a little more unpleasantly than I wished. The iodine seemed to be ripping the skin from my back and in so savage a manner that the pain of it kept me awake till four o'clock next morning. By that time the iodine had finished its work. In a few days the scorched cuticle began to peel and continued its peeling until my back was as bare as a skinned catfish. Then I wondered how long it would be before I could boast of a new suit of skin. (I might say in parenthesis that although my back had worn the old one for fifty years it was still a good deal better than none at all.)

However, "Everything comes to him who waits" and the new suit reached me as the old one left. I had no fault to find with its fit and it will probably wear me the remainder of my days, unless I should again tumble into the iodine bottle of a village doctor.

How about the lumbago? Ah! I am sorry to say it still lingered and seemed to be in no hurry to leave. But it did leave finally and in this way. I had been out hunting on a caribou bog for six days, jumping from log to log, climbing over "dead-falls" and dodging the branches of the juniper and spruce trees. The motions attendant upon these athletics caused me much discomfort, as my lumbago kinks followed one another with a rapidity and an energy that threatened to throw me off my pins. However, 
I weathered through the exercise, but the lumbago didn't. It soon became disgusted at my stubbornness and left me as suddenly as it came. Whither it went I know not, unless in search for the lumbar districts of some passive victim, where it may get in its work undisturbed.

My trip down the Penobscot River consisted of a glorious run of twenty-one miles. We left the carry at one thirty and reached Chesuncook Lake at eight o'clock.

Running through Rocky Rips on our way down, we heard two moose wading in the water near the shore. The moon was shining, but the shore was darker where they were than if there had been no moon; so we couldn't catch even a glimpse of them. Below Pine Stream Falls we heard another of the same sort feeding in the water. We paddled swiftly to where she was feeding (it was a cow-moose), but she heard us and got out of the water in double-quick time, rusbing through the woods and crashing through the alders, at the same time giving vent to her alarm in loud trumpetings.

At Pine Stream Falls it is customary for the "sport" to get out of the canoe and walk through the woods along a well-defined path which follows the stream. I had brought with me a new invention which is something like a music roll in shape and size and fitted with a powerful lens at one end and a 


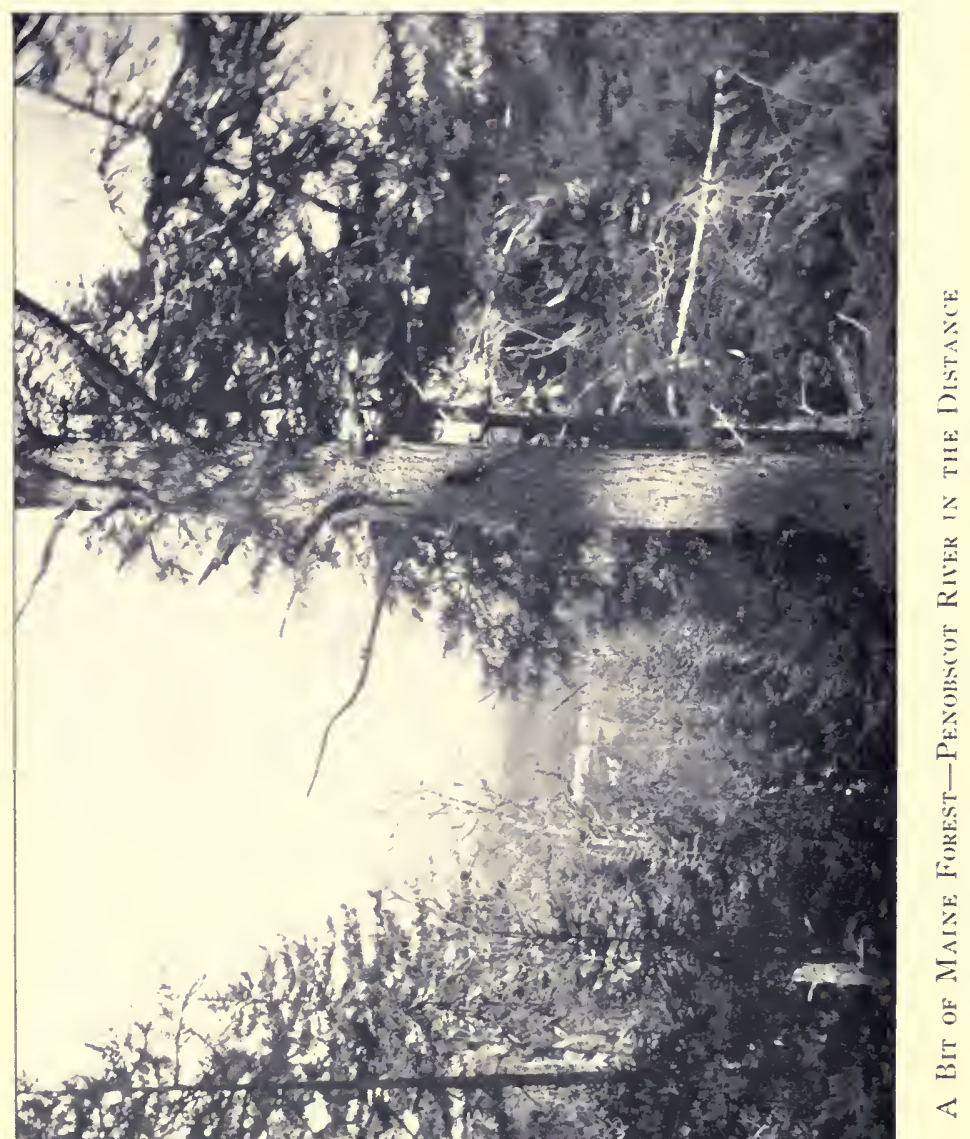





\section{A CARIBOU HUNT}

dry electric battery at the other. By pressing a ring a fair sized light is produced. Carrying this in one hand to light my path, and with my rifle in the other, I walked leisurely along. As I approached a clump of high swale grass that lay ahead of me, my light flashed along the path and lit upon a deer that stood in the middle of the clump. She straightened herself up and gazed at the light with wondering eyes, as if the unwonted sight had hypnotized her. She allowed me to approach within a few feet of her, and as she looked in awe at the light, I looked in wonder at its mystic reflection from her orbs of vision-a green, weird glow that fascinated me. Thus we stood gazing at each other for five minutes or more; then shifting the hypnotizing rays from her eyes I bade her a loving good-night, and, with a laugh at the quickness with which she bounded into the darkness, I trudged on my way.

When Thoreau, the naturalist, came down this piece of river in 1853 , he found two Indians near the North East Carry camping out and drying and smoking moose meat for their winter's food. He spent a night with them. They had killed twenty moose, mostly cows, and were curing the hides as well as smoking and drying the meat. In his trip down the river he saw one moose, which his companion killed, but no deer. He passed down again in 1857, talking the Allagash River and lake in his trip, 
and again his companion killed a moose, and again they saw no deer. It is only of recent years that the latter have become so numerous as to excite little comment, and I firmly believe that the moose also are increasing in numbers; but the caribou are becoming extinct, or perhaps are leaving because their foodthe black moss which grows on the juniper trees-is becoming scarcer as the years go by. Some lumbermen claim that a disease is killing the juniper trees in Maine. If this be so, the caribou will probably wend his way to the maritime provinces of Canada where he can find moss in abundance.

I spent one week on a caribou bog, traversing it from centre to circumference and becoming familiar with all its nooks and crannies, its alleyways and its main rendezvous. Frequently did I sit watching the caribou cows-and beautiful they are, too, and as sleek and fat as thoroughbred Jerseys. On one occasion I met one of them face to face, and she was not more than twenty feet from me. She looked at me earnestly for some minutes and then turned slowly about and walked away. Twice she repeated these movements but at neither time did she show the slightest fear or any alarm.

I devoted the most of my six days in searching for the "King of the Bog" - a fellow with a royal pair of antlers. I picked up what I presumed was the set he had discarded in the previous spring. They were 


\section{A CARIBOU HUNT}

somewhat eaten away by the mice, but there was still enough regal beauty left to entitle them to an honored place in my collection where they now hang. If I was right in my supposition that they were worn by his highness the year before, their number of points told his age to be twelve. My son and his guide had succeeded in getting a glimpse of him, some two weeks before; and I, after six days of watching and stalking, sitting and standing and lying down, also got a glimpse.

But it was a stingy one. In stepping through the bog I had carelessly broken a twig with my foot. Then I heard a snort away off to my right, and looking in that direction I saw a cow bounding away with the gentleman I was after in front of her. I recognized the big fellow as he passed between two trees, and that was all.

I have heard of a negro melody entitled "Hesitate, Mr. Nigger, Hesitate!" and possibly his imperial highness had heard of it, too. A dozen times or more had my ears been tickled with the racket he made in rushing through the growth of spruce that borders the bog, and striking his antlers against the trees. Yet he wouldn't step out into the open and show himself. When it seemed certain that he was about to do so, he would hesitate, as if he were listening to the darky melody and deemed it provident to follow its advice. He was wise. "Hesitate, Mr. Nigger" succeeded in 
saving his lordship's bacon-at least for a while, for I decided to give the bog a rest for a few days and move to another camp about eight miles away.

My week upon this bog that I left was one of the happiest I ever spent in hunting. Two days of it I was in my shirt-sleeves, two days with a vest on, and two with a coat. This tells the story of the weather -it was fine. The distance from the camp was a little short of two miles, and, as I took the tramp morning, noon and evening, it made about twelve miles of steady walking.

The bog is a "dry bog," its dryness being readily accounted for. The spaces between the trees are filled with a wanton growth of blueberry bushes, whose decaying leaves, year after year, have helped to raise the surface of the ground so that no water rests upon it.

The place teems with all manner of life, except the human variety. The fox hunts his breakfast there, and the bear dines and sups sumptuously on its ripe blueberries. It is the home of the red squirrel, the mole and the field-mouse, and they may be seen darting hither and yon, busily employed in getting their living among the medley of vegetable growth.

Here, in this garden spot, I would sit by the hour, secluded from the world and forgetful of its cares and perplexities ; resting both mind and body, and with a species of rest unknown to the busy city man-and which, by the way, he will never know, unless he 


\section{A CARIBOU HUNT}

will occasionally drop his treadmill work and try it.

Doubtless there are some who will think me insane to call the seclusion of a bog restful, or to recommend such an occupation as caribou hunting as a sovereign remedy for the ills of the body and soul. Or they may consider it the essence of absurdity to spend a whole week in tramping orer bogs in search of that animal, and then, like a hermit, solitary and alone, to sit down on a log, and meditate.

Alone, my friend? You make a mistake. I was not alone. It must be a man of little soul and less sentiment who thinks himself alone when he has Nature at his elbow. And she was at mine, opening, as it were, a drama before me, and for my express edification. I looked upon it and wondered at the sight; wondered at the wealth of her life-her plant life, and her strange animal life, whose strangeness is so notably marked in her caribou. Alone my friend? No. It is true I was the only mortal among her audiencethe only human "looker on in Vienna"; and I will say that no stage representation ever enchained my attention so tightly or afforded me more food for thought and study. Alone? Oh, no! These "goodly creatures" of the bog were to me more genial company than would have been that of men and women, with nerves and temper and energy and strength jaded and worn by the fantastic fads and customs of civilized life. No, reader; I was not alone. 


\section{$A$ Lost Moose}

Sheathe thy impatience.

-Merry Wives of Wrndsor.

Out in the Maine wilderness and some eight miles from where we had located our cabin is an old logging camp which is rapidly tumbling to the ground. In the days of its prime it had housed nearly sixty men, but now it is merely a harbor for hedgehogs and legions of field-mice. The portion of the structure which was used for sleeping bertlis is stripped of the roof, every passing guide and hunter taking a share of the cedar splits to build a fire or sheathe his little cabin. The ends and sides of the building still stand, but they are all that remain to give one an inkling of its former glory.

Within its walls the weary choppers, drivers and sawyers were used to take their rest, smoke their pipes, tell their yarns, sing songs, and dry their wet clothes. The shanty, when I saw it last, was damp and mouldy, and smelt very loudly of rotten wood, old clothes and dilapidated rubber boots. A collection of empty medicine bottles and salve boxes had been left in the bunks, telling most plainly that the lumbermen had not escaped their share of the pains and aches and 96 


\section{A LOST MOOSE}

bruises and inflammations that the rest of the world is heir to.

A party of gum-pickers were the last occupants, and to keep out the rain and make the place tolerably habitable they had patched up a corner of the roof. Under this portion they built a couple of bunks in which they slept at night and sometimes rested during the day when wearied by their toilsome work. A rude table stands in the middle of the floor, and in its decaying wood the gum-pickers had cut their names and told their occupation. The latter was hardly necessary, as the quantity of worthless gum scattered upon the floor should have saved them that trouble. The road that passed by the lumber camp was much traveled by a pair of moose, and runs near a bog where I oftentimes found caribou. Now it struck me that it would be a good idea to spend a night or two in this camp, first fixing up a place on the front part where I could sit at night and watch for passing game. My mind was really bent on getting a shot at the moose whose footprints showed his daily wanderings up and down the road and to the stream, for the purpose of feeding along its banks at night. I said to myself "What an easy thing it will be to sit at the opening in the front of the camp, and when these big fellows come along, put out the muzzle of my rifle and bang away." Of course my plan had nothing to do with the cow-moose, only the bull; and he must be a 
big one at that. But alas for my program, and for all human speculations when a bull-moose is at the bottom of them!

I directed one of the guides to carry up my bedding, a few slices of deer meat, some bread and a large onion; this he did and then left me to my cogitations. These were full of the moose and caribou, and spiced with the thought that, like Selkirk, I was " monarch of all I surveyed."

I spent the afternoon on the bog, my heart swelling with a hunter's hope and pumping its valves so fiercely that a caribou might have heard the throbbings had he been near enough. But he was too wary to venture so close. It is true there were many of them in the bog, and they came near enough to get a scent of me; but when they got it, it seemed to be all they wanted, for their stay on or around that bog was cut off very short. In a word, they slipped away without my getting even a glimpse of them.

As I was stealthily picking my way back again, however, a cow-moose dodged through the trees in front of me. I stopped for several minutes and then crept forward a few feet until a new vista opened up in the spruces. I looked and listened for sounds of any kind, but heard none. Presently a noise came from what appeared at first to be a forked branch away off to my right, and I finally made out that it was a cow-moose. I thought she might have her 


\section{A Lost MoOSE}

beau with her, and therefore kept perfectly still so as not to alarm either of them. If the bull wasn't with her he might be somewhere within her call and perhaps would join her.

It was half-past three in the afternoon when her form was first fully outlined. I stood motionless and she did the same-save once in a while her great ears would be moved a little to catch any strange sounds. The seconds ran into minutes, the minutes into nearly an hour, yet there she stood and in the same pose. It was now so dark that her head, ears and shoulders formed simply a dark, undefined spot. I was completely fagged out and stole softly away. As I left her, she showed no movement of a muscle, and for aught I know, she may be standing there yet.

With a sigh of relief I hurried back to mount my point of observation because I felt sure that the pair of "wanderers" I was after would pass my way early in the evening. The guide had fixed up a sort of a platform by laying a door across two boxes on top of the sleeping bunks, and this would bring my shoulders upon a level with the sill of the square window in the gable. Mounting the platform, I sat down to await events. They were not long in coming. I soon heard the sounds of heavy "breaking" down the road, intermingled with the tender tones that characterize moose courtship. I now moved a little, to bring my left shoulder clear of the opening, and 
cocked my rifle. The click of the cocking was not loud but it stopped the advancing pair of moose lovers as if they had run up against a stone wall. They stood there for a second or two, and then wheeled about, started for the woods, and got away. This was my last moose experience, so far as they were concerned, and it taught me a lesson. Had I but waited until they were directly in front of me, one good shot and that bull lover of hers would have been "settled for life."

It is needless to say that my pride was sadly bruised by the result of my impatience. Every hunter, as you may surmise, is blessed with plenty of pride, and it is so thin-skinned and so easily bruised that if a moose should escape him without, at least, a damaged limb he never forgets his faux-pas nor forgives himself. Therefore, ye sports, I will hatch a precept for the use of him who may need it,- -and it would be well for him to paste it in his hat:- "Sheathe thy impatience" and you'll miss a multitude of disappointments. 


\section{The Big Moose of Little Tobique}

A conquest for a prince to boast of.

-Hexry IV.

Boastixg is the badge of the fool. No dyed-inthe-wool sportsman will use it, for he knows too well that his exploits are not due solely to his skill. It is true that the writer succeeded, where other ambitious "sports" had failed, in capturing the "Big Moose of Little Tobique," but this was not because they had been less expert, but for the reason that he had more luck and perseverance. Luck is a potent factor in the hunter's success, and none knows the fact better than himself.

And now, in the words of the crook-back Richard, "I will retail my conquest won" and as briefly as its attending incidents will permit.

The Tobique River flows into the St. Johns River about a hundred miles from the mouth of the latter at the city of St. Johns, New Brunswick, Canada. The Tobique has four branches and these unite at "The Forks," sixty miles from its mouth, and are named the "Serpentine," the "Sisson," the "Right-hand branch" and the "Left-hand branch" or "Little Tobique." The latter rises in the two Nictau Lakes and these get 
their life from a great spring at the base of Bald Mountain - the tallest, broadest and longest in the Province, being 2,700 feet high, five miles long, three broad, and surmounted by an almost level plateau. The spring bubbles up volumes of water, so cold that a hand placed in its gush soon becomes numbed; and so clear that the trout can be seen darting and turning up their speckled sides at the bottom.

Whence comes the supply for this inexhaustible spring? Probably the rainfall on the broad surface of the Bald's top, instead of running off in streams, filters through the mass of earth and rock, to feed a subterranean reservoir, whence through some syphonic power it is forced up to the base of the mountain.

For thirty-two miles along the river above the Forks, the country is almost a virgin wilderness. The chopper's axe has not as yet invaded the Nictau Lake region; and its broad stretches of land give the moose and the caribou all the food they require and the seclusion they covet. The lakes themselves and the "dead-waters" on the small streams are fringed with lily-pads and other aquatic growths that please the palates of these strange animals. Here they may nibble their breakfast, and drink, and attend to their courtship, secluded and undisturbed-unless some "Peeping Tom," in the shape of a liunter, should upset their program. And he often does.

During the open season, September 15 th to De- 


\section{BIG MOOSE OF LITTLE TOBIQUE 103}

cember 31st, hunters of all stripes and from almost every civilized nation resort to this region and with one purpose-to kill a bull-moose or a bull-caribou. But all are not successful. If they were, the pride of the expert would soon lead his sporting into a more uncertain channel. Uncertainty is the charm that captivates the hunter, and he finds all he wants of it in the chase of the moose and caribou. If he succeeds, he considers himself lucky. If he fails in securing his antlered trophy, he swallows his disappointment, and without the sauce of excuse. Mind you, I speak now of the expert hunter. From the lips of the other sort excuses will fall "thick as autumnal leaves that strew the brooks in Vallombrosa." By the way, this quotation from Milton is not a happy one, for the blind poet seems to have "put his foot in it" when he created the simile. The forests of Vallombrosa are made up of pines whose foliage is not deciduous; therefore the brooks can never be strewn with thick autumnal leaves.

To return to my story. I arrived at "The Forks" on September 19th, and here my guide and cook met me. They said my son was camped some five miles away from the river and near two little mud lakes. On the margin of one they saw the tracks of a moose, and from their great size were convinced that none other than the Big Moose of Little Tobique could have made them. 
We had some eight miles to paddle up the river before reaching the road that led to the camp, and during the trip the "big fellow" was the main topic of our talk. The guide described his enormous tracks, and told of the many places where they were seen. There could be no mistake, for the foot of no ordinary moose would fit them. The shores of many lakes, the dead-waters and the soft places in old roads all bore evidence that he must have been a great stroller, a tramp, the "Weary Willie" of his tribe. All this tramping was, of course, done in his search of some fair one that would listen to his tale of love. Whether he found her or whether the "fair ones" all preferred the fate of a young bull's slave to that of an old one's darling is a question whose answer I will leave to zoological wise-heads.

On the river we met my son and his guide. The former had killed a couple of bears a few hours before, and was full of bear-talk rather than moose-talk. But he did take time to corroborate all the marvelous stories of the "big fellow" and his tracks. On our way we passed a lake, reported to be one of his haunts, and we stopped to look for a trace of him. Tracks we found indeed, but I thought they were not made by the fellow we were after. They seemed too long and the hoofs spread too far apart. Moreover, the animal's dew-claws had made a plain impression in the mud, therefore I presumed it to be the footprint of 


\section{BIG MOOSE OF LITTLE TOBIQUE 105}

a giant caribou. Unlike the moose's, the caribou's dewclaws are almost on a level with his hoof, and combined with the wide opening of the latter they enable him to travel over the snow as glibly and tirelessly as if shod with snow-shoes. The hunter may, and often does, run down the moose in the snow, but if he attempts it with the caribou-well, in the pithy vernacular of the street Arab, he will bite off considerably "more than he can chaw."

As we reached camp the sky overclouded and the rain began to fall, and for four days and as many nights it kept on falling. I can assure the reader that when it does rain in this "blue-nosed" region it makes a business of it and does nothing else. I say bluenosed, for 'twould be hard to find a New Brunswick man with a nose of any other color. Funny? Not at all. The nose, as every one knows who has a nose, is the most sensitive of all meteorologic instruments. It is the "poor man's weather-glass" and 'twould be funny indeed if the uninterrupted cold rains and chilly fogs didn't have the effect of changing the color of its tip.

During the four days of rain the growth of fungi, edible and inedible, was wonderful. Mushrooms galore, of all shapes, sizes and colors sprang through the earth's crust and so hurriedly that a poet might imagine they had been roused from their embryonic nap by the wand of a magician and were fearful of 


\section{SPORT INDEED}

being late to breakfast. However, I am no mushroom crank. My acquaintance with the Basideomyces tribe is slim-much too slim to risk my stomach's welfare in their leeping. In other words, I am always in doubt whether Innocence or Death lies hidden under their kid-like caps.

But wet weather and mushrooms have nothing to do with the "Big Moose," and so we'll get back on his track. On our first afternoon in camp my guide made the birch-bark horn with which he hoped to lure the old fellow within rifle-reach. Accoutred with this, together with rubber blankets, a lantern and a rifle, we started for the lake, reaching it a few minutes before the daylight vanished into night-and the blackest one within my memory. We called and listened and strained our eyeballs trying to peer through the dense pall that hung around us. A pair of moose did come to the water and-as their footprints indicated next day--came very near us. But we didn't see them, and probably would not have seen them had they stepped over us. However, we knew they were there, and fearing they would get on our scent if we stayed through the night, at ten o'clock we groped our way back to camp. Next morning at four o'clock we started again for the lake. The walk was not a pleasant one for the rain was still splashing the road and dripping from the trees. At a quarter to five we reached our "sanctuary" of the night before, 


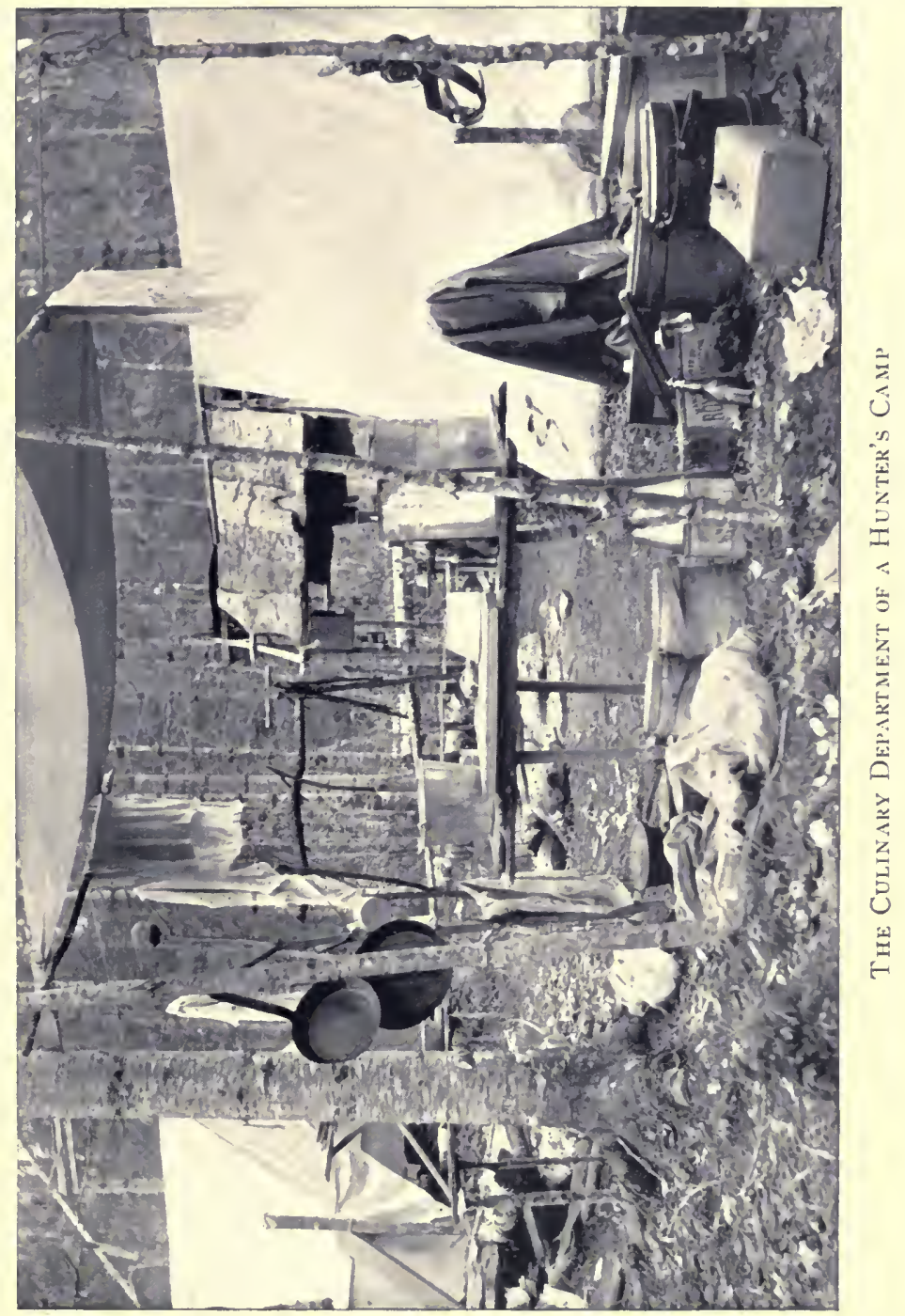





\section{BIG MOOSE OF LITTLE TOBIQUE 109}

but were too late. The two moose-lovers had departed in search of "woods and pastures new." However, they left their tracks behind. One was a young cow-moose; the other a bull of ordinary size, and we wanted neither of them. Our heart was fixed on big "Weary Willie" and he had not been in their company.

The following night we changed our position to a clump of cedars that stood on a point jutting out into the lake. During the day I had walked twelve miles to reach an old beaver pond and meadow, said to be a haunt of the caribou, and during my absence the guide had "swamped out" a path from the road to the cedar point above mentioned. This enabled us to reach or retire from it silently - an impossibility by the old way, as it led through a cedar swamp full of dead branches and rotting wood.

About four o'clock the guide, who was alone, heard a branch crack on the edge of the lake, and turning his eyes in the direction of the sound, got his first glimpse of the big fellow upon whose capture we were so eagerly bent. The man had no rifle with him, nothing but his axe, which he laid noiselessly down and crept back to the camp, where he awaited my return. When I did get back, we started at once for the cedar point, and during our walk, he edified me with a glowing description of the Big Moose-tramp, his marvelous size, his dignified walk, his shape, etc. 
We reached our hiding-plaee at the point only to find that "Willie" had left for parts unknown. The guide tried his birch-bark horn, but the dying echoes of its notes were the only reward for his trouble. Onee we fancied that the big fellow was listening in the fringe of the woods on the other side of the lake, and when we heard the sound of antlers striking against the branches, we were sure of it. But alas for the certainty of a hunter's ealeulations! Antlers they were, but not the antlers we were after. They belonged to one of the lovers that eame so near stepping over us in the darkness of the night before. After we diseovered this, we left them to their billing and eooing and returned to eamp.

The next morning we rose at half-past three. It was still raining, and after a cup of tea and a biseuit we tramped onee more to the lake. The moose-lovers were not in sight, but we could hear them as they walked leisurely up the slope of the ridge in front of us. My son had seen this same couple a few days previous and described them to me. "The bull," he said, "has the queerest head I ever saw. The antlers shoot straight up like two half-opened fans standing on end and showing their flat sides to the front. The lady-moose is very tall, graeeful and sleek-looking and seemingly without a spark of timidity."

I had spent the better part of a day-Friday-in tramping over a ridge and visiting another pond. 


\section{BIG MOOSE OF LITTLE TOBIQUE 111}

The tramp covered perhaps twenty miles, and when again I reached our clump of cedars, tired nature cried for a rest. As our plan was to lie out all night, we had brought blankets with us, also a steamer rug, but had left the latter under the butt of a fallen tree further down the lake. After the guide had cut a few spruce boughs to make a mattress, I sent him back for the rug and then threw my tired limbs upon the spruce boughs. Twenty minutes or more passed and the guide not returning I thought he might have seen a moose on his way back and feared he might scare him by returning in a direct way to the cedars. Raising myself slowly from the spruce boughs, I looked around me, and felt convinced that I was right in my conjecture. A hundred and fifty yards away, and directly within the line of trees on the far side of the cove and to my left, I was sure I saw the young bull with the upright antlers. He stood "head on" with his body shielded by the trees, leaving his head and neck alone visible. To shoot or not to shoot was the question, and I had to decide quickly, for the scant daylight was fast melting away in the coming night. A moment of doubt, and then, after careful aim, I fired. I looked, expecting to see the fellow drop. But he didn't drop. This rather astonished me, but there was more astonishment in store-he hadn't moved. Putting in another cartridge, again I fired and again I looked. The upright antlers were still there in 
statu quo. "Thomas," I said to myself, "is thee daft or dreaming?" The question was not an unreasonable one and to satisfy myself whether I was either or both, again I loaded up and again banged away. Before I had time to note the result of the last shot, the guide rushed in out of breath.

"What are you shooting at?" he asked.

"A bull-moose; there he stands; don't you see his head sticking out from behind that tree?"

With a loud laugh he replied, "Yes, I see it; I saw it this morning; and I would advise you to waste no more of your cartridges on the turned-up root of an old cedar stump."

A cedar stump! Shades of the mighty Nimrod, had it come to this? Could it be possible that my eyes could see no difference 'twixt a moose's head and a cedar stump? The guide's pill was a bitter one, yet I swallowed it, and then asked him if he had found the rug. He said no; that he had looked under the butt of every fallen tree, but couldn't find it. "Well," I said, "I will go and get the rug, and in the meantime you keep your eye on that root and tell me if it moves." I then left him mumbling something to himself about the probability of a cedar stump moving.

On my return, I decided that he should go to the lower end of the lake and "call," for if the pair of moose did come in they would be likely to visit the cove. After he left, I looked for the cedar root and it 


\section{BIG MOOSE OF LITTLE TOBIQUE 113}

wasn't there. The stump, or whatever it was, had vanished. Here was a mystery, and not a pleasant one for a sport to ponder on, especially if he prides himself on being a tolerably good shot. Again I looked and then rubbed my eyes in wonder. The stump was back again and in the identical spot it had occupied before.

Just at this moment I heard the guide give a "call" on his birch-bark horn. No echo followed it, for the woods were still soaking wet; but it sounded very like the plaintive call of a disconsolate lady-moose, and its effect upon the antlers of my cedar stump was magical. They dropped at once out of sight and in a second or two reappeared. The mystery was solved. It was a moose indeed, but only a cow-moose. She had been standing like a statue, and what I thought were antlers were only her big ears which, standing straight up and thrown forward, really looked like the pair of antlers my son had described.

The reason why my three shots had missed her was plain enough. She had been standing between two trees, with her head turned towards me almost at right angles with her body, and the bullets had all entered the intercepting tree which, in the uncertain light, I had mistaken for the foreshoulder of a moose. At the sound of the birch-bark horn she changed the position of her ears, and then I had no doubt of her sex. Nor was her gentleman attendant far away. 
The male-moose, though always watchful over his mistress, is very careful to keep in the background if he scents danger in air. He heard the guide's call, and, as he moved up and down behind the shelter of the trees, gave his answer. It was not a loud one, but it was loud enough to reach the ear of his frau, and affectionate enough to arouse her jealousy. A moose-wife is very like the human-wife in her notions of conjugal propriety, and has as little toleration for her husband's flirtations; therefore, as soon as she heard him answer the guide's loving call she began to scold, and in a manner that told him he must stop that sort of thing or she would know the reason why. I had instructed the guide to call not oftener than once in fifteen minutes, and this intermission gave the bull time to quiet down. But her ladyship still stood there, scolding away with all the vim of an Irish washerwoman, when the horn sounded the second time. Again the unfaithful partner of her bosom began to strut about behind the cedars, breaking the branches with his feet and hitting them with his antlers.

At this moment a far-away bark-or rather a halfbark and a half-grunt-struck our ear. It was another bull-moose answering the call and his answer was bold and clear. "The "unfaithful hubby" that had been strutting so proudly heard it too, and the effect on him was curious. He stopped his strutting instantly and became as quiet as a lamb. 


\section{BIG MOOSE OF LITTLE TOBIQUE 115}

Again came the far-off bark, but this time much nearer than before. The guide answered it with a low, plaintive call intended to indicate that her counterfeit cowship was extremely delighted to have her R. S. V. P. answered so promptly.

The birch-bark horn was now laid aside, for the bull was coming with mighty strides, breaking the branches under his feet and crashing his antlers against the trees. In the meanwhile the lady-moose on my left had stepped out into the water. Though I did not see her, I could hear her drinking, and also heard her mate wade in, splashing the water around him. But the other chap we were so eagerly waiting for was quiet. Not a sound came from his direction. He was either stealing down to the water on tiptoe or standing still and listening. And thus the minutes passed. The pair of moose-lovers had drunk their fill, and now we heard them in the darkness nibbling at the lily-pads.

To the right of where I was lying, and perhaps fifteen feet away, was another piece of ground with a wet, sticky bottom of gray clay, and in this I first saw the footprints of the Big Moose of Little Tobique. Turning myself to the moose-lovers on the left and looking towards the right, I saw the flash of a light. My first thought was that the guide had struck a match to light his path toward me. But quickly as the flash came, just as quickly did it disappear. I laid for a moment puzzled, and then saw what puz- 
zled me still more-a star peeking through the trees and close to the earth. While I was wondering what business a star had there when there was none overhead, it suddenly flickered out. In the fraction of a second a double star took its place. My comprehension at last was master of the situation. The light of the match, the star and the double star were one and the same-phosphorescent gleams from the eyes of the big moose. $\mathrm{He}_{\theta}$ had crept stealthily down to the water and was now close to me-so close that his breathing-and he had no "bellows to mend"-was plainly audible. I was lying behind a log and at one time fancied he might take a notion to step over it, and drive me into the earth with those big feet of his. But he didn't. I had my electric lamp with me and turned its rays to the right and to the left of me, then to my head and to my feet; yet I saw nothing around me but the ghostly, cedar branches. However, the three moose must have seen the illumination, and yet strange to say, it didn't startle them. Just then I heard a whistle out on the road. It mocked the note of a bird and was a signal from the guide that the moose had passed him on the road to the water. Ah, he little knew how near I was to the big fellow! Howerer, there was one thing that I knew-it was essential that I get away, and get away quickly lest some tale-bearing zephyr should inform the intelligent noses of these animals that a human 


\section{BIG MOOSE OF LITTLE TOBIQUE 117}

being was on their track. And yet I was afraid to leave until the big fellow would step into the water. This would show me that his suspicions were lulled. Nor could I shoot, because I couldn't see him. Had the guide been with me he might have handled the electric lamp and its flash would have been sufficient to direct my aim, had I been disposed to take advantage of it-which I would not have done, for such an act would have been unlawful.

My hunting experience has often placed me in situations of intense excitement and anxiety, but none of them contained as much of either as the present one. I waited, it seemed to me, an age for the big fellow to move. At last he made one step into the water, and now came my chance. Leaving the blankets and rug where they lay, and pointing the glass bulb of the electric lamp to the ground, I tiptoed over logs and under branches and through bits of water and across bits of corduroy road, and did it all so gently and quietly that none of the creatures I had left behind heard me. If they had done so they gave no evidence of it. I was glad to reach the road with the conviction that my moose companions were still nibbling their lily-pads in peace and in the unconsciousness of danger.

The guide assured me that my friend the moose could be none other than the Big Moose of Little Tobique. "I know this," he said, "by the manner in 
which he answered my call. But I didn't know you had two others on your string. I was afraid you had fallen asleep."

Asleep? Hardly. If five hours of pent-up anxiety and excitement-five hours of close companionship with three moose-if this is not enough to keep a hunter's eyes open, he must be drowsy indeed. It was an experience I wouldn't have missed for the price of my vacation; an experience bulging with events of kaleidoscopic variety. The cedar rootthe queer antlers-my three shots-the first bull's attempted infidelity-his scolding wife-the lighted match - the phosphorescent stars - the stentorian lungs of the big bull-the wait for his step into the water-the wait to reach the road-surely Queen Mab might find enough material in all this to stuff my dreams for inonths to come.

At three o'clock the following morning we were up and ready for our parts in the last act of our moose drama. A light breakfast, and then with our rifles and electric lamp we trudged again through the mud, the wet and the pitch-like darliness. 'Twas no wonder' that the mile-and-a-half to the lake seemed like a dozen of them. Slowly and silently we trod, for we were certain the moose were in the water, and the noisy break of a branch or a stumble would have ended our hope of getting a crack at them. As we came nearer the cove, we listened and caught the 


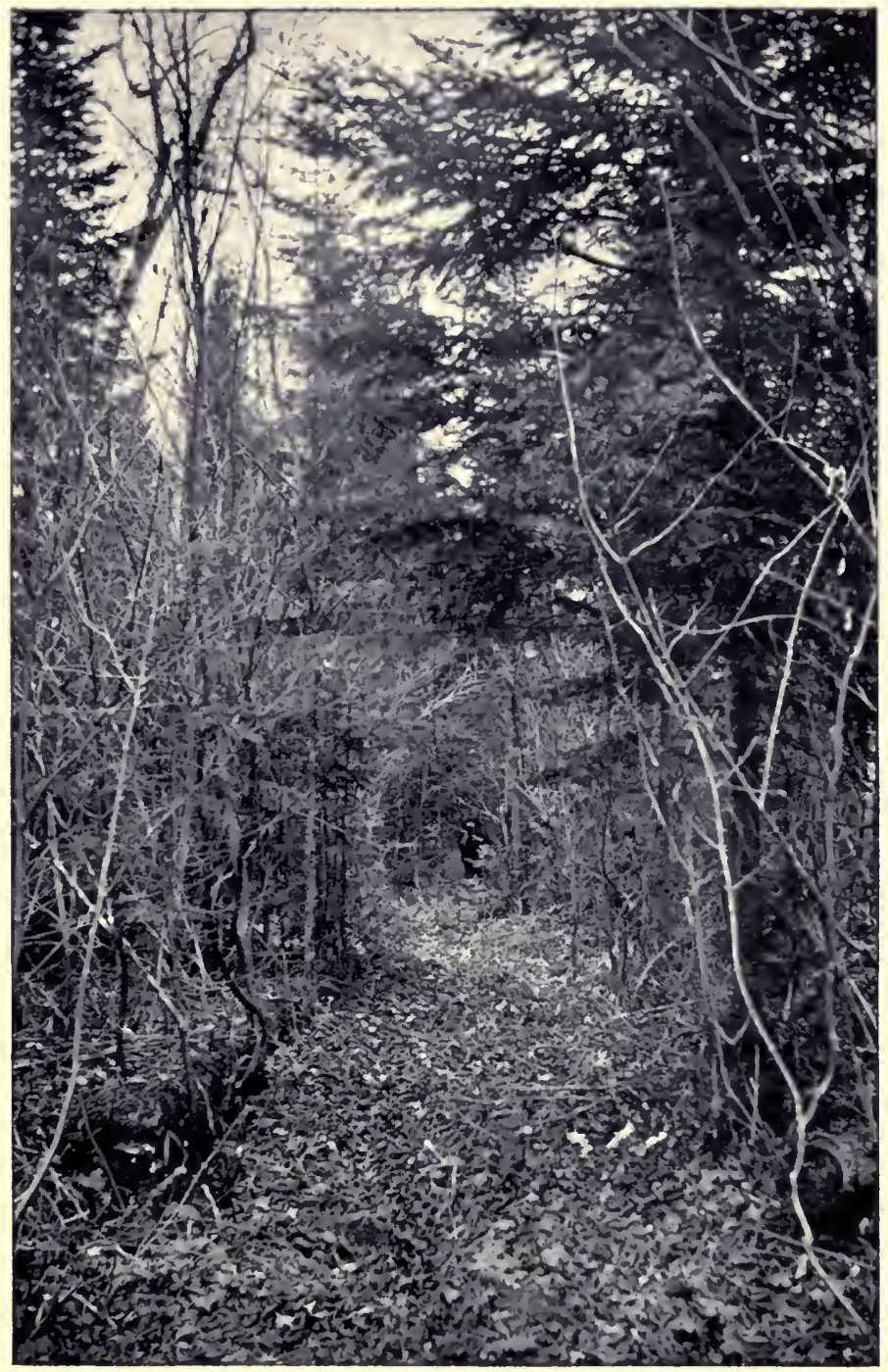

A New Brunswick Tote-Road-The Authur in the Distance 



\section{BIG MOOSE OF LITTLE TOBIQUE 121}

welcome sound of splashing. They were there! But now the most difficult part of our journey lay before us-the entrance to the cedar point, and through the cedar swamp. There were two paths; one by way of the cove and the other in which we would follow the footsteps of our moose No. 3. We took the latter, thinking that all three animals would likely be together in the cove. I led the way, pointing the light to the ground. The guide followed, both of us treading carefully and shying away from every dead twig. We could not have trod with more circumspection had the road been paved with dynamite. Three old, dead trees lay in our path. They were without bark and so slippery with rain that both of us thought it safer to get over them on our hands and knees. Then came the soft strip of gray mud; then a couple of rotten and moss-covered spruce logs; and then the clump of cedars. To get inside of the dense cover of the latter we were again forced to resort to our hands and knees, and so crawled into our lair. The day had not yet broke and the darkness was impenetrable. There was but one thing to do-or rather two things-wait and listen. We felt sure that if the moose would remain till dawn our victory was certain. And thus in the darkness, waiting and listening, we passed the anxious minutes, hoping and praying for the dawn. It came at last, yet when it did, and I looked into the cove, my eyes as yet saw 


\section{SPORT INDEED}

nothing they could shape into a moose. My ears, however, were en-garde, telling me plainly that a moose, perhaps the big fellow himself, was at the bottom of all that wading and splashing. And then my eyes began to get their work in. Something, that in the glimmer of the breaking day they took to be the top of a fallen tree, had changed its shape. 'Twas not a tree now, but a moose and a monstrous one. Was it a bull or a cow? I couldn't tell for its back was toward me and its head in the water. But our doubt was of short duration. A few minutes, and the great beast turned around and started on a walk straight toward us. And now luck was at my elbow ready to do her part in the capture of the big fellow. Following the line of the shore he came directly around the cedar point where we were waiting for him. His appearance as he walked majestically around the point in the light of the hazy morning reminded me of the picture of a "mammoth" that I had seen in my boyhood days, painted upon the side of a building and used by the firm as their trade mark. Some thirty years have passed, yet I haven't forgotten the "mammoth."

To return to the big fellow. He seemed in no hurry, but stepped along as if time were made for slaves and not for a bull of his dignity. He had evidently eaten his fill and was on his way to some favored spot where he might rest and sleep, and so 


\section{BIG MOOSE OF LITTLE TOBIQUE 123}

prepare himself for another night's flirtation. But alas! the best-laid plans of a moose, like those of mice and men, "aft gang aglee." Leisurely he approached until he came quite within range. Then the sharp crack of a rifle rang out on the air and the flirtation days of the "Big Moose of Little Tobique" were ended forever. The ball had pierced his heart and he fell in his tracks a few feet from the shore.

The guide gave me a shake of the hand and a congratulatory hug, and then jumping over the prostrate quarry tried to slew him around so we might pull him out of the water by his hind feet. In this we didn't succeed. So I told the guide to go to the camp and bring the cook-a strapping big chap-and also a rope. Fastening the latter to one of the moose's hind feet, we managed, after a deal of pulling and twisting and turning, to get our prize on terra firma. Then we took a good look at his tremendous size, and the sight of such a mountain of moose-flesh nearly robbed us of our breath.

Examination showed us that we were not the only sports that had followed his big heels with murderous intent, for there was a bullet hole in the left blade of his antlers and two buckshot holes were in the right.

His feet were a study. Six and a half inches from toe to heel was the measurement of the largest moosefeet I had hitherto seen, but this fellow's covered eleven and three-quarters. They were chipped and 
ragged and worn awry under the unnumbered miles of his midnight tramps. However, the chiropodistic skill of the taxidermist has remedied all that. $\mathrm{He}$ has cured and polished them and now they are quite fit to adorn a room, and quite able to prove their owner's right to his title :

The Big Moose of Little Tobique. 


\section{The Lost Wallet}

Thereby hangs a tale.

-MERRY WIVES OF WINDSOR.

'Tis a slippery world that we live in-so slippery, indeed, that it often puzzles a man to travel its glib paths and keep on his feet. Nor are its paths the only slippery things. Money, for instance, has a reputation that way, and I, for one, can vouch the reputation to be deserved.

By the way, what is money? Iago defined it as "trash," but the oily rascal's lexigraphy, like his love for the Moor, was a little lop-sided. The world's definition, I think, hits nearer the mark: "Money is a something that no fellow can get along without." As Owen Meredith once said-or rather, neglected to say :

We may live without wisdom, may live without wit;

We may live without pluck, or the thing we call grit;

We may live witlout brains-if we've plenty of gall

We may live without using our noddle at all ;

We may live without sweets, withont sugar and honey,

But where is the fellow can live without money?

No; the man who lacks it finds himself in what he calls "trouble," and his friends, though willing enough to acknowledge his strait, are not always so willing to help him out of it. 
As for the "gay sport," I believe he is seldom afflicted in that way; although he is thought to be, and probably is, less cautious than other people in his care of the cash. The latter has a go-easy manner of getting away from him, but he doesn't care a continental how easy it goes, provided it leave behind its quid pro quo in the shape of his enjoyment. There may be times, however, when a little financial care on his part would be advisable. If, for instance, he happen to be in the wilds of a forest, hundreds of miles away from his bank account, and with all his available funds lying in a wallet in his inside pocket. At such a time prudence should dictate that he keep his mind's eye on the leathern receptacle and not let it get beyond his reach-at least, without his knowledge and consent.

Now, to a man who "travels on his shape" the absence of a stuffed wallet may be of little consequence. But "the sport" is not built that way. His stock of "shape" is limited, and even if it were not, his manhood would probably rebel against getting through the world in such a questionable manner. $\mathrm{He}$ is in the habit of paying for what he gets, and-I speak feelingly-sometimes for what he doesn't get.

But to return to my mutton, otherwise my wallet, I will relate how that leathern receptacle did get beyond my reach and without either my knowledge or consent. 
It was a part of my hunting luck to spend a couple of nights in a series of old camps, one of which was without any roof and the others with only a bit of one large enough to cover a corner. I was alone, so far as the company of mortals was concerned, but of the other sort I had plenty. I was surrounded by wild neighbors whose tracks showed they were in the habit of frequenting the camp yard to eat of the grass that grew upon a pile of camp refuse and manure, and also to take a lick or a nibble at the old salt-pork barrels which lay bleaching and rotting in the sun and rain.

The camp wherein I made my bunk was damp and smelt as foul as an old cellar. The rain had free access to it, but the sun hadn't, therefore it was not strange that the floor should be dank and green with mould. Old boots, and rubbers and discarded clothes were scattered profusely about acting like so many sponges to catch and hold the moisture. At night when I passed from one camp building to the other I carried an electric lamp. This was imperative in order that I might not lose my way or break my neck in winding through the labyrinth of empty butter and nail kegs, old tin cans, etc., etc.

During the early part of my first night there I had been watching for a moose from behind an opening in the gable of one of the buildings and had taken my wallet from the inside pocket of my vest. This was a matter 
of precaution, for, with every breath I took, the wallet would give a creak; not much of a noise, to be sure, but enough to catch the ear of the moose I was expecting to pass that way. When the night became so dark that I could no longer see, I put the wallet in the hip pocket of my trousers and returned to the other building containing my bunk. Then I undressed, crawled into my sleeping bag, and was soon in the land of oblivion. About one o'clock I was aroused by the whistling and stamping of a deer close to the camp. During my nap the night had grown so very cold that I reached for my trousers and sweater and, putting them on, crawled again into my sleeping bag and slept till sunrise. My sleep, however, had been troubled by a dream in which my wallet played a conspicuous part. Now I am not posted in the philosophy of dreams, but those who profess to be assert that these mysterious visions are sure foretellers of coming events. In my case the dream was not out of the way regarding the loss of my wallet, but it slipped up a little on the manner of the loss. I certainly had no hole in my trousers' pocket, which the dream said I had; nor did the wallet keep me busy in picking it up and replacing it a dozen times before I discovered there was a hole. But these were trivial error's. Suffice it to say the dream was vivid enough to make me jump up, as soon as my eyes opened, and thrust my hand into my trousers' pocket. There was 


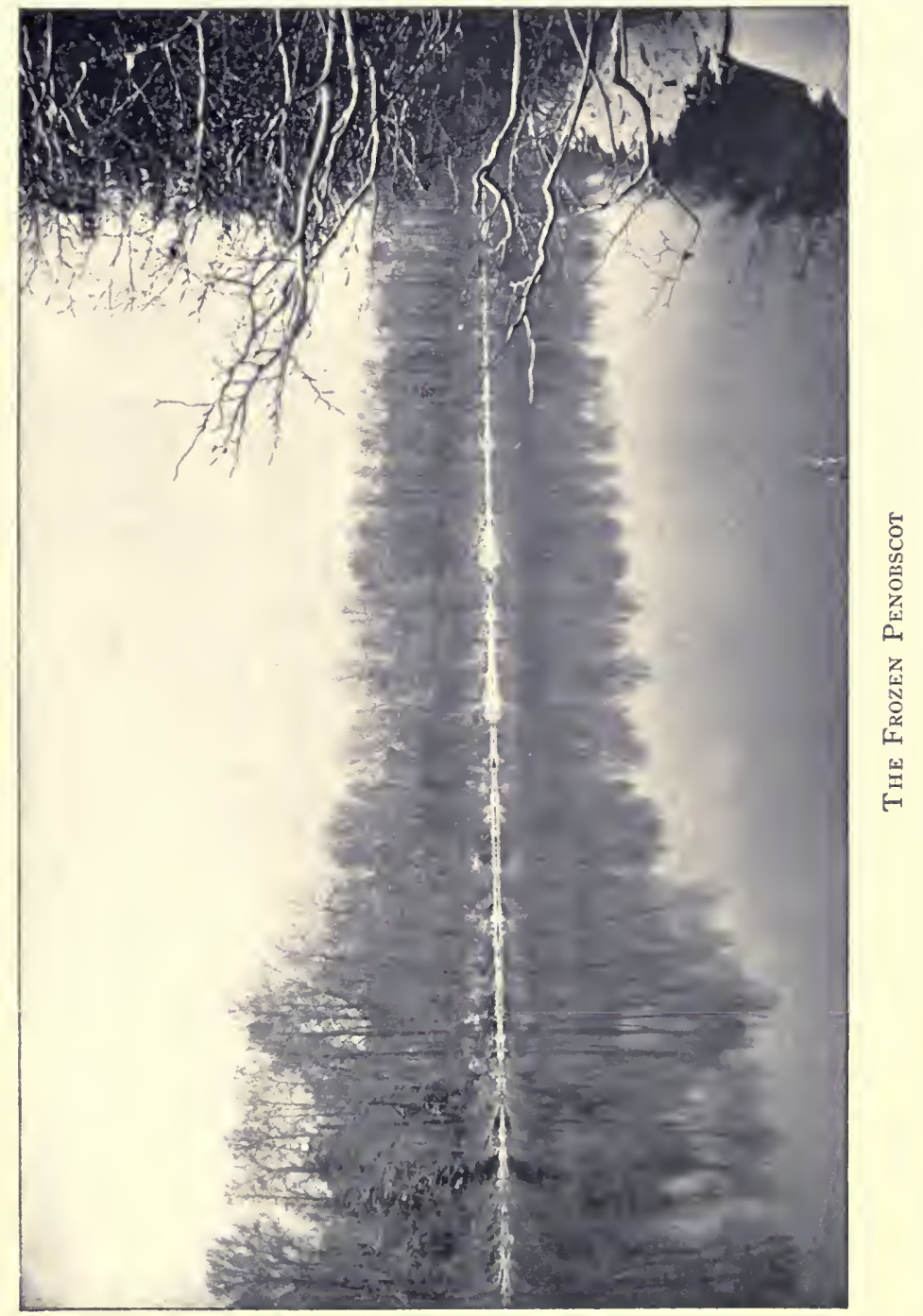





\section{THE LOST WALLET}

no hole there, neither was there any wallet. There could be no more doubt about my having put the wallet in that pocket the night before, than there was a certainty now that it was somewhere else. But where? Could I have dropped it on the bog? This seemed probable and I started at once on the search. When I tell the reader that there was $\$ 135.00$ in it for me, he may not wonder that I did my best to succeed. It is true, $\$ 135.00$ is not a fortune, but it is a good deal better than nothing; and nothing was sure to be the something I would have if I didn't find that wallet. Therefore eagerly did I search, following my tracks of the previous day, tramping on them back and fortl and examining every place to which they led. But all to no purpose. No wallet was to be seen. Somewhat out of temper I returned to the camp, took off the spruce boughs from the bunk, and shook out the blankets with the hope that the wallet might turn up. But it didn't. Then I went outside and sat me on a $\log$, and I will venture to say that there was more solid thinking done on the top of that $\log$ at that time than will ever be done there again. At one end of the log there was a soft piece of ground in which I saw tracks that looked to me like those of the porcupine. Instantly my wits began to work and in detective fashion: "If those are a porcupine's footprints his home is probably somewhere under this very camp. If so, may not my wallet have fallen from the 
bunk while I was asleep and have been picked up and carried off by this prickly thief?" The thought started me back to the old camp to examine the floor. It was made of long thin logs, the surfaces of which were chopped off with an axe. Between two of these logs was a space just wide enough to allow the wallet to drop through-that is, if it were dropped directly over the crack. But the logs were laid at right angles to the bunk, so that if the wallet had fallen over the side, it must have reversed itself in order to slide down the narrow slit. This seemed improbable, but not enough so to dampen my hopes. I determined to pry up the logs, and with an old axe that was lying in the corner I soon made a wooden crowbar for the purpose. One of the logs had a bend in one end which caused the opening I have referred to. I placed my bar under this log, ripped it from its place, and found, as I had expected, that the ground underneath had been well furrowed with porcupines. Striking a match I looked down into the hole. The dim light showed me no wallet, and I struck another match with a like result. Then I tried the electric lamp, and its light enabled me to explore thoroughly all the nooks and crannies of a porcupine's home. And there in one of these nooks, and totally unconscious of the anxiety it had cost its owner, lay my green wallet. It was unharmed, excepting that it had four marks which it bears to this day. Whether these were made by the 


\section{THE LOST WALLET}

claws or teeth of my friend the "fretful porcupine," or by some other agency, was then, and is now, a mystery. But there is another and a deeper mystery which neither Time nor mortal ingenuity is likely to solve: how the deuce could that wallet crawl from my trousers' pocket, jump from the bunk, turn a somersault, and dive into the household of that porcupine? 


\section{A Close Call}

Escaped with the skin of my teeth.

-Јов $19: 20$.

OF all the things in this world which are not picturesque, the breaking of camp after a long season spent in the woods of Maine comes close to being at the top. We had spent many long and exciting days in the wilds of Maine, and camp was broken at six in the morning. The camp had been on a high ledge, overlooking a circular sheet of water known as Moose Pond. The latter is flanked by bogs on two sides, a cove at one side and a stream that runs into it from a small lake above. It was a dismal day, and the three guides looked glum when we started to make our way out of the pond and through the cove into the lake beyond. The wind blew directly in our faces, and the guides seemed to be afraid of everything. First they were afraid they could not get the canoes around the point, then afraid they would have to camp on the shore of the cove-in fact, there was nothing they were not afraid of. Finally, my son and I told them that if they would only put us on the other side of the cove we would lighten the canoes by walking the two miles across the point and through the woods. 


\section{A CLOSE CALL}

Well, we started, and, although it rained buckets of water, I rather enjoyed the experience. We found many fresh tracks of big game, the windfalls were few, and as the path was deeply carpeted with freshfallen leaves the walk was anything but tedious.

On leaving the forest the road led through a piece of burnt land. I heard a cow-bell jingling and soon spied some cattle feeding off to the right, and, straight in front of me, were two deer. But they had scented me, and as they threw their heels up and bounded away, I tried a shot at the nearest one, but-ah, there's that "but" again!-I missed, and the deer, in a tivinkling, were safe in the timber.

We reached the lake and then had a long wait for the canoes. On their arrival we found one of them had shipped a good bit of water, and that they all had had a narrow call from capsizing. The wind was increasing every minute, and as it was necessary for us to cross the lake (here about a mile and a half wide), we put the baggage into one canoe, and, with our strongest guide to handle the stern paddle and me at the bow paddle, while my son squatted down in the centre of the canoe, we pushed out into the turbulent waters. The wind was blowing a gale straight down the lake, and strong enough to pick the water from the tops of the white caps and blow it around us in the shape of fine spray. Our course lay diagonally across or up the lake in the teeth of the gale, and hardly had 
we gotten a hundred yards from shore before my son's "sou'wester" hat was knocked off by the guide's paddle. But that was no place nor time to stop for a hat. The canoe mounted and rode the waves beautifully, and yet at times it seemed as if the wind would capsize it or blow it out of the water, particularly when we reached the centre of the lake, and the canoe was turned obliquely down towards the other shore. Then we had to paddle for our very lives and watch the waves to see that they didn't break orer us. When the light canoe was going down the sloping sides or in the hollow of a big wave, we had to use every pound of our reserve strength to shove her along before another mountain of water caught us. It was indeed a ticklish trip, for had we capsized we would have had no show whatever in the icy water, as our heavy hip boots would have prevented any chance of our swimming or of a rescue. We fully appreciated the situation. However, we got over without mishap, other than a wetting, a lost hat, and a profuse perspiration from hard paddling. We were safe, and for this we devoutedly thanked the Ordainer of all things.

We stopped for dinner at the little frame hotel, the Chesuncook House, which is the last sign or semblance of a hostelry you see before plunging into the great wilderness beyond. Among those who were making the hotel their headquarters were three sports who went out in the morning to hunt and returned at 


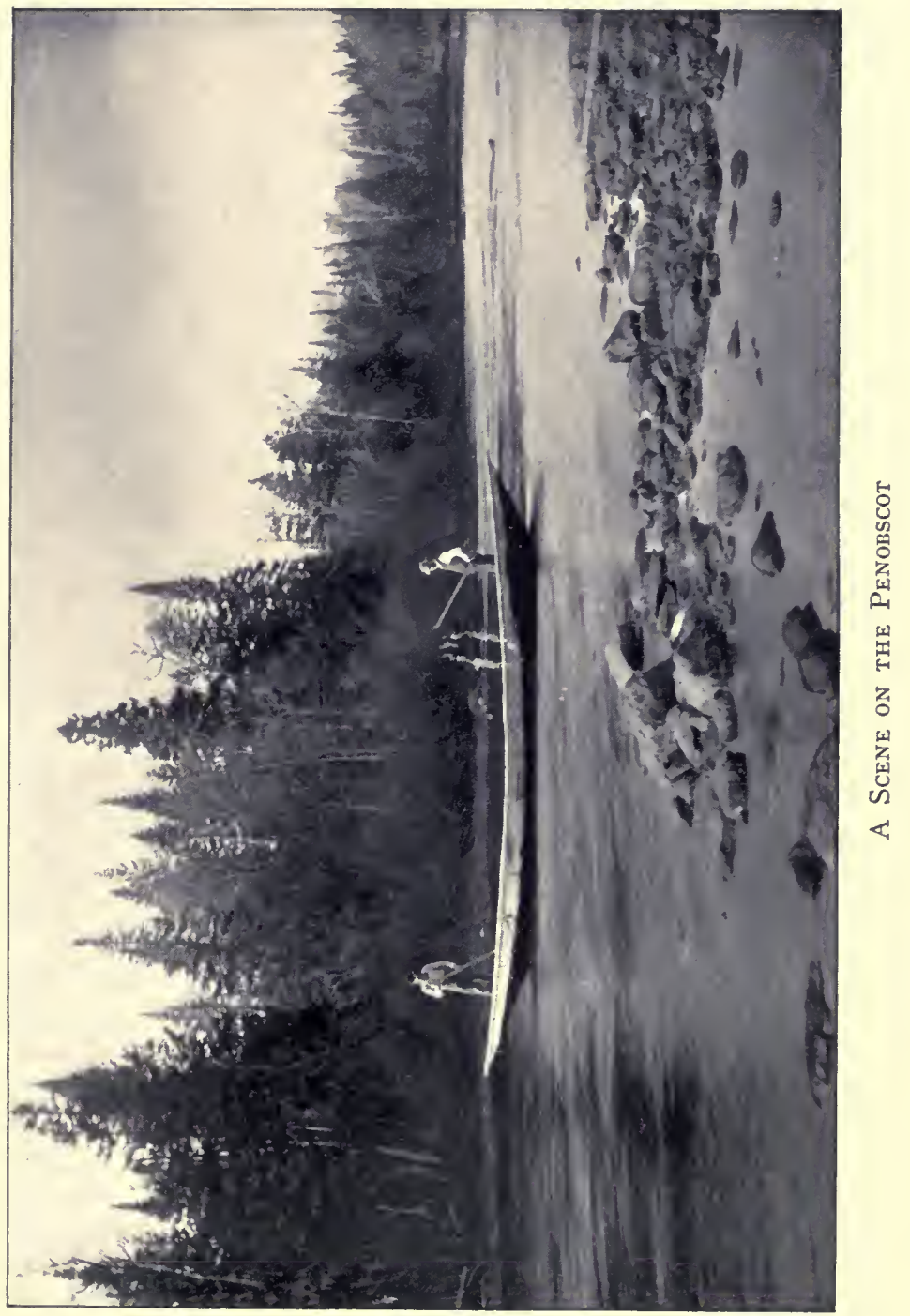





\section{A CLOSE CALL}

night to recuperate. They had killed a nice buck the day before our arrival and had set it up on the shore of the lake for inspection. It was hanging from a trident formed of three poles, and while the rain beat upon it and the wind swayed it to and fro the hunters watched it with admiring eyes; and well they might, for it was a beauty.

Now, two of the aforesaid sports were from Woodbury, N. J., and the other from Boston. The Boston man and one of the Woodbury men were built on the corpulent model, extremely oily, and with a girth that might have rivaled Falstaff's. But they were not sensitive on that point, as some oleaginous men aremen to whom the slightest reference or even glance in a stomachward direction would be at once a casus belli.

Our conversation at dinner turned upon the treatment they had been experiencing from their guides. "Do you know," said the Boston man, "I have had the most unpleasant experience rubbed into me by these guides and I don't care to have the operation repeated."

"What was the nature of the operation?" I ventured to ask.

"Well, you probably have noticed that I have a good deal of butter in my make-up and I don't care to have it all melted at once, which seemed to be what these guides were after. They told us that the Ambezuskas meadow was a glorious place to hunt in, and 
so it may be for a lean man; surely no fat man could find any glory in it unless his fat be of a more unmeltable quality than mine. Inagine three hundred pounds of flesh floundering through mud and water, tripping over cedar roots, falling over logs, struggling for a little temporary foothold in order to pull oneself out of the mud and regain an upright position, while the guide stands at a safe distance away, beckoning and shouting 'come on!' After this part of the programme had been repeated several times, always winding up with 'come on,' tired Nature gave out and refused to comply with the guide's mandate. Mounting a stump I gathered together what little strength $I$ had left and put it.all into a shout, "You be d-d! I'll not "come on" any more. "Come on" yourself, that's what I'm paying you for." "

His story, by the way, reminds me of another which is short enough and good enough to fit in here. Two would-be deer hunters, one thin and wiry, the other round and oily, had struck a trail and the thin fellow lifting his eyes saw a big buck bounding directly towards them. "There he comes! lie down!" shouted the thin chap, but seeing no reduction in the obtrusive size of his companion again he shouted, "Lie down! Lie down!"

This time an answer came from the direction of the butter pile. 


\section{A CLOSE CALL}

" $\mathrm{D} \longrightarrow \mathrm{n}$ it all, I am lying down!"

"The d_Ll you are! Then stand up and perhaps the buck won't see you."

We left Chesuncook Lake at half-past one in the afternoon, fixed our loads in the canoes at a landing stage near the mouth of the river, and in the driving, pitiless rain, we started to paddle up the stream, intending to reach the Halfway House, about eleven miles up, before dark. On the trip up the "sport" is expected to leave the canoe and walk around the stream's obstructions known as the Pine Stream Falls, Rocky Rips and the Fox Hole Rapids, while the guide, with the lightened canoe, poles it up against the swift current which swirls and eddies around the huge rocks lying in all sorts of ways and angles in the bed of the stream. We walked therefore through a path in the woods around Pine Stream Falls and the Rocky Rips, and above them was a stretch of dead-water which ended at the foot of Fox Hole Rapids. Here we left the canoes again and took to the road which runs in a nearly straight direction, while the river makes a great bend off to the right, and the road for the distance of, say a mile and a half, cuts off quite a detour in the river. Just as we entered this road I told my son to walk ahead very carefully until he came to a piece of burnt land which my recollection said was a feeding ground for deer, and he might get a shot. As he emerged from the 
woods I saw him stop on the burnt land and take his rifle from under his arm (it was still pouring rain). I saw him aim and fire and a deer bound away, while the youth jumped over burnt timber and scrambled through stunted blush. Again I saw him aim and fire, and I saw the deer drop. Now we were in a pickle; night was coming on fast and the canoes were away off to the right. The rain was splashing down in torrents. There was no time to wait, so we at once opened the deer and took out the "in wards," cut a sapling with our knives, ran it through the "hocks" of the deer, slung it on our shoulders and started for the road. This road is called a "tote-road" by courtesy, and in winter it is much used for hauling supplies on when there is a good depth of snow.

In summer and fall it is not much used, and there are rocks and roots upon it, and holes in it that would shame the "Slough of Despond." It was now dusk, and soon became pitch dark. And the rain, how it did pour! We stumbled and slid along over roots and water and mud, swaying from side to side with our unwieldy load, rifle in one hand and the other steadying the pole on our shoulders, every now and then tramping on the deer's head which hung and dragged on the ground. So for the mile and a half we trudged along until the canoes were reached.

Here we found the guides angry and alarmed at our prolonged absence, and, as they were soaking wet, 


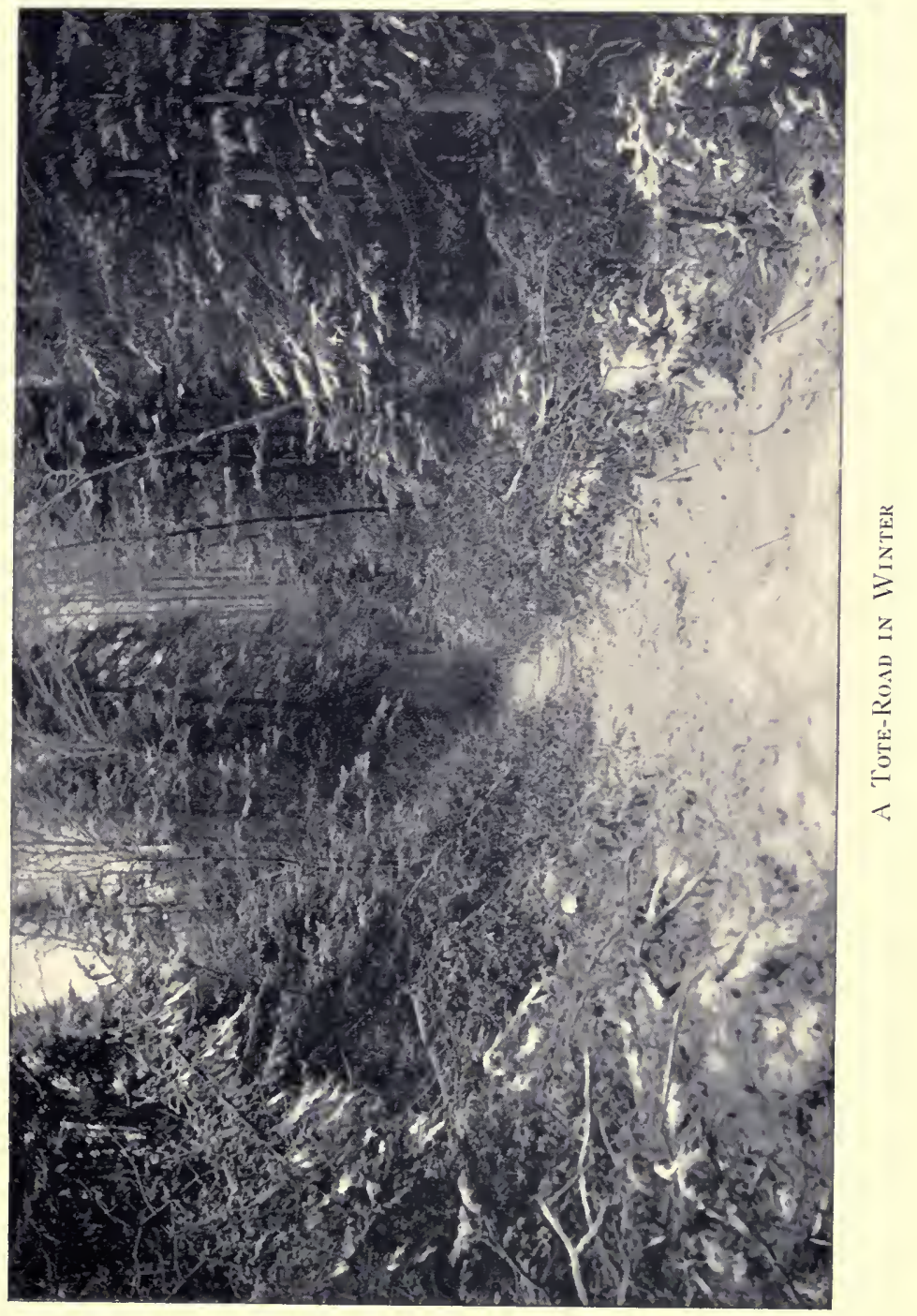





\section{A CLOSE CALL}

we couldn't blame them. We got into the canoes again and paddled briskly until we saw a welcome light shining ahead at the Halfway House. This house is built away up on a clay bank, and set far enough back from the river to prevent the Spring and Fall floods from washing it away. Now a steep, clayey bank on a night when the water is pouring down is not a nice one for a lot of half-frozen, halfdrowned men to clamber up. We slid and slipped here and there, now down and now up, until we were well-covered with clay; but we were cheerful withal, and that's a great deal towards contentment. We at last reached the house, had our baggage brought in, and to our disgust found everything was wet-overcoats, blankets, underclothes, negatives, etc., etc. A big fire was built in a big stove. We ate supper, hung our wet clothes around the fire, emptied all of our luggage sacks and hung the contents of them upon the chairs and benches as well as upon the wall. After this task we went to bed and were soon wrapt in the sweet sleep that comes to all men who labor in the open air and know how to make the best of storm or cold or any other of Nature's unpleasant pranks which she may be pleased to play upon them.

At half-past three the next morning we tumbled out of bed, ate a hasty breakfast of bread and butter and bacon and coffee, repacked all our things in their proper sacks, carried them down and placed them in 
the canoes. Then before the goddess of morn had time to get her eyes open, we pushed off for our last canoeing trip of that season.

The pouring rain had now ceased and the weather had turned so cold that the water froze upon our paddles, and the river was so nearly frozen that there was little or no spring in the canoes. 'Twas a dead push all the way up to the Northeast Carry. We had not been able to draw on our leather boots by reason of their soaking of the night before, and rubber boots had to be substituted; and these, in that biting cold, made it uncomfortable paddling. After a run of four miles we were glad to push the canoes ashore, build a fire and warm up. At about nine o'clock we landed at the Carry, hired a wagon to tote our stuff over to Moosehead Lake and then walked the two miles of good road which constitutes this famous Carry.

When we reached the little hotel at the lake end of the Carry we had to wait several hours for a steamboat to take us to Greenville, forty miles away, whence the train is taken for Bangor. Here I noticed a youth who looked feeble and sick, as if nigh unto death. He was a farmer's boy whose home was near Hartford, Conn. The boy had read and reread stories of hunters; of their happy lives in the woods, and their ignorance of restraint, and pored over them until his brain had room for nothing else. The reading of Cooper's novels had so fired his imagination 


\section{A CLOSE CALL}

that he resolved to live the life of a hunter, and to do it he believed that nothing more was needed than to go into the woods with a rifle and a rubber blanket. This was no theory with him to dream over, but one to act upon. He came alone from his farm, went alone into the woods and very soon stalked a deer which he succeeded in killing. Then his youthful breast beat high with rapture as he saw the noble quarry lying at his feet. But hunger must be appeased, and he was hungry, no doubt about that. He dressed the deer, cut a steak, still reeking with animal heat, built a fire, toasted the venison on a stick and greedily ate it. Then spreading his rubber blanket upon the ground and without either a blanket to cover him or a sleeping bag to crawl into he laid him down in the frosty air and slept the sleep of youth and tired-out nature. Next morning he awoke with shivering body and chattering teeth and a burning pain in the intestines. Hanging up his deer in a tree as well as he could, he built a fresh fire and tried to warm his body and dispel the chill which at last gave way to a fever and a splitting headache. The morning passed, noon came, and night, and there he lay. On the morning of the second day, prone upon the ground, with the red squirrels busy about him gathering their winter stores, the poor boy lay. Here, sick, far from home, from kindred, from mother's care, or doctor's aid, he was found by a party of lumbermen 
who carried him to their camp and nursed and fed him as well as they could for six days. Then as the winter was fast closing in they sent a man out of the woods with him to the Carry, and here I saw him. His attendant asked me if I would look after him as far as I went. I told him nothing could give me more pleasure than to do so.

When the steamboat arrived I took him aboard, got a sofa for him to lie upon, and then looked over my medicine chest. Picking out some tablets, which had a very little of morphia in them, I gave him one of these every three hours and made him drink hot milk with some cayenne pepper in it.

We reached Greenville very late at night, left at six the next morning and arrived at Bangor about noon, leaving the latter sometime in the early afternoon. At these places, and wherever and whenever I could get the hot milk, I made the poor boy drink it. At Portland, I had a doctor examine him who said that the boy was certainly in the early stages of typhoid fever and that he also had intestinal catarrh, caused by the eating of the venison before it had parted with its animal heat. The doctor also said that the tablets I had given him were "right" and that the hot milk was "right." We reached Boston at nine o'clock in the evening, and thinking that the train I was to take was the same which was to carry the boy to his home, I took him to the Providence depot, but found I was 
mistaken, and that he had to go by the Boston and Albany Railway. My time was short and his, too. Checking my own baggage I engaged my berth, then left my son with the remainder of the stuff and started for the other depot. It was raining heavily, and at that time of night I could find neither carriage nor street car, and so was compelled partly to support and carry, and partly to drag the sick boy on the way. We reached the train with five minutes to spare. After buying his ticket I helped him into a car, laid him down and then hunted up the conductor -a portly, pompous, beggar-on-horseback sort of a fellow-and asked him if he wouldn't kindly look after the boy to the end of his division and then ask the following conductor also to see to his comfort. His reply was perhaps what I might have expected. "No, sir! I have no time to look after sick people. I've got my train to attend to, and if the boy gives me any trouble I'll put him off at Worcester and send him to the hospital." A man was standing near him (probably a railway official) who had listened to $\mathrm{my}$ story and request and to the conductor's reply. $\mathrm{He}$ turned quickly to the man of brass buttons and swinging lantern, and spoke with a frown. The words were few and their purport I did not catch; but, whatever it may have been, the change was magical. The conductor came toward me and in the most polite and cringing manner promised to look 
after the boy. Then the semaphore over the gate changed from red to white, the bell rang, a shout of "All aboard," and with measured puff the train was on its way.

My own train was to leave at midnight and I hurried back to it through the rain which pelted in torrents and wet me through. However, it took but little time to get undressed and into my berth. A few moments afterward I felt the train moving out of the station, and then all knowledge and recollection took a back seat. I knew nothing until I awoke next morning at my destination, fully aware that the hunting season was over, that I was back among my friends and loved ones, sound in mind and limb, revived in brain and ready for any amount of work. Verily,

\section{" Hunting is an exercise}

To make man sturdy, active, wise ;

To fill his spirits with delight,

To help his hearing, nıend his sight,

To teach him arts that never slip

His memory ; canoemanship, And search and sharpness and defense, And all ill habits chaseth hence." 


\section{The Fun of Hunting}

I love the sport well.

-Two GeNtlemen of VeroNa.

YES, I love the sport of hunting and love it well, especially if a bull-moose or a caribou be the object of it. To be sure it entails several things which the citybred tenderfoot might call discomforts, such as wading through watery bogs, tumbling into mudholes, sleeping in wet forests, and, should his lumber muscles have the temper of mine, a struggle or two with lumbago. My own comfort and the sport itself have often been at loggerheads and had many a spat; yet I always sided with the sport-" Not that I loved Cæsar less, but that I loved Rome more."

One of my trips found me at the Nictau Lakes, but the continuous high winds in that region interfering with the hunting, our party turned their faces homeward. We spent part of a day in shoving down the Tobique River to Red Brook, a distance of twelve miles. Here we hid the bulk of our supplies in the mouth of an old lumber road, and taking as much of the stuff as four of us could handle, carried it over two ridges to a "dead-water" on a small brook seven 
miles from the river. Then we located ourselves at an abandoned lumber camp and spent the night there. It was decided that my son should take up his quarters at the foot of one piece of dead-water and I at the head of another, a mile and a half away. The sky was threatening and rain began to fall at two o'clock in the morning.

We watched and called at intervals till dawn began to break; then wearied with watching and chilled to the bone I crawled under my blanket.

The guide had wandered down the stream, a hundred yards or more, to where it is crossed by a little bridge. Here he stopped for the purpose of taking a drink of water. As he stepped on the bridge, he saw a bull-moose move cautiously out of the woods and head for my direction. The guide watched him intently, and when the moose would malie a step he would do the same, so as to not attract the animal's attention by the noise made in walking. The moose took the opposite bank of the stream, walking a few steps and then stopping to listen. Whenever the bull stopped, the guide also would stop, and thus a considerable time was spent before the latter reached the place where I lay snuggled under my blanket. By the time the bull got directly opposite to me, the guide had reached a clump of alders, behind which he stood and within earshot. Ile did not dare to gire the moose a chance to see him, but I heard him say in low, 


\section{THE FUN OF HUNTING}

measured tones, "There's a bull-moose standing right across the brook in the edge of the woods. Don't get up too quick, but be swift with your shot and don't miss him."

Before the guide had finished his instructions I had my rifle out from under the shelter of the rubber blankets and cocked. Then, slowly raising myself to a standing position, I saw the bull. He saw me, too, and turned quickly around to make his way into the woods. But my rifle was a little quicker than the bull. I fired, and the ball struck him squarely on the left hip-bone, crushing its way through it and dropping the big fellow in his tracks. But it took two more bullets to finish him.

After breakfast we went to work skinning and quartering him. When this was done we undertook the more delicate task of removing the scalp from the head and cleaning the skull for mounting. Then we hung up the meat to cool off, and salted the hide and head.

After dinner we explored and discovered another dead-water two miles off, on the Restigouche Waters. The little stream that formed it was less than a hundred yards from the Tobique waters, upon which we were hunting.

A caribou bull broke cover, some three hundred and fifty yards away, and ran directly across the level. This incident decided us to try the same dead- 
water that night, with the hope of getting a shot at one of his tribe. We returned to camp, packed up our bedding, took a ferv biscuits and a small pail of water to comfort us during the night, and again reached the lower end of the dead-water at five o'clock. We cut an avenue into the alders, cleared off a bit of ground, laid our blankets down, and tried to find out if there wasn't another stretch of deadwater further down. At the very extreme point of an open space was a bottomless mud-hole and diagonally across it an old cedar tree had fallen. It was necessary to cross over this tree to work our way down the stream. The guide got on the small end of it and, with a pole, worked his way safely over; then it was my turn and I was equally successful, until the butt-end of the tree was reached. Then the old cedar crushed with my weight, my left foot came in contact with one of its broken slivers, and in a jiffy I was off the $\log$ and into the mud-hole. It was lucky for me -however unlucky it may be for my readers-that an alder branch on the bank hung within my reach. No drowning man ever snatched at his proverbial straw with keener haste than did I at that alder branch. With its aid I began to pull myself out of my predicament; it was slow work, for the mud seemed determined not to let me slip from its slimy clutches. However, I did get out of them, and when I stood on the bank I looked about me for my rifle. Like a 


\section{THE FUN OF HUN'TING}

faithful friend it had followed me on my plunge, and I now saw it rapidly disappearing in the hole, buttend first, and, for all I knew, on its way to the antipodes. The guide saw it too, and reaching over caught it by the muzzle, in time to stop its mad, or rather mud-career, and proudly restored it to the hands of its owner.

Its "owner's" hands, as well as every other part of him, needed some restoring. My trousers were bedaubed an inch thick with the sticky stuff, and my drawers so thoroughly soaked that I wondered if ever again they would be dry. But I consoled myself with the old Dutchman's proverb: "Dime dries all dings," and thought, in the course of events, it might "dry" mine.

But as my comfort was not disposed to wait for time to do the work, I started the guide on a run to camp for fresh clothing. Then I pulled off my boots -no easy job-divested my legs of the drawers and trousers, and then in bare limbs trudged through the wet grass to a neighboring brook. I brought with me my boots for the purpose of ridding them of the mud that loaded them inside and out, and also brought my watch, cartridges, matches and compass. The latter articles I had taken from my trousers' pocket and tied in a handkerchief for convenient carrying. I reached the brook and commenced my washtub business, but before I got through with one 
boot my task was interrupted by a hungry swarm of black flies. They had discovered my nakedness and began at once to satisfy their hunger, picking out each tender spot and boring into it with such vigor and determination there was nothing left me but flight; and I flew.

Now, to walk or run in bare feet is good for the health-at least, so said good Father Kneipp; but if he had ever had any experience in walking or running through cold spring water, waxey mud and sharpcutting swale and wire grass he might have admitted some exceptions.

When I reached the shelter of the alders, my watch, shells, compass and the other things were missing. They had dropped from the handkerchief unnoticed in my hurried flight and I was forced to tramp back and hunt for them. Twice did I make the trip, each time through a cloud of the flies whose hungry appetite seemed to grow "by what it fed on." As a fretful horse tries to shake off his tormenting biters by stamping his feet, so did I endearor to rid myself of mine. Nor was it my feet alone that were busy. My hands were quite as fully employed. I whirled them about my face and ears and slapped my neck, my shoulders, and my legs until they grew red and I grew weary.

I found the watch at last, hanging by its chain to an alder bush which had caught and dragged it from 


\section{THE FUN OF HUNTING}

the handkerchief. The shells and other missing things were under the alders.

It did not take long to get me into my sleeping bag, cover up, and forget all about my tormentors. In an hour and a half the guide returned with the dry underclothing which I put on, and was then ready once more to brave the raw air and the hustling flies.

I might remark, by the way, that if the plague-fly of the Egyptians was a more accomplished biter than is the black fly of New Brunswick, in the lingo of today, he must have been a "dandy." 


\section{A Fire-and-Water Medley}

Spit fire! Spout, rain !

-KING LEAR.

"Tre property of rain is to wet and fire to burn," -a hackneyed truism of which our New Brunswick camp had rather a damp and lucid proof.

The rain had been falling heavily all day. TVe knew it was the intention of a party, consisting of two sportsmen with their guide, and one woman, to come through and camp at the head of the Tobique River, but thought they would prefer to stay at Red Brook, twelve miles below, until the storm abated, rather than expose themselves to its fury in their canoes.

Toward evening the storm let up a little, and with my guide I concluded to venture out for moosecalling. TWe stayed out until eleven at night, and then the wind became so strong again and the rain so heavy we paddled back to camp.

Our main camp was a rather primitive log structure, with a wooden fireplace, made by setting long split logs on end, forming a chimney and a ventilator, and affording light as well as heat. There was no window of any kind. As a sleeping place the cabin might 156 


\section{A FIRE-AND-WATER MEDLEY 157}

have accommodated five men comfortably, had it not been utilized also for cooking purposes; but being thus used, five sleepers crowded it a little too thickly for comfort.

Imagine our surprise when, on this dark and stormy night, we opened the door of the cabin to find its inside crowded with seven guides, two sportsmen and one woman.

They had been all day dragging up from Red Brook, twelve miles, for the water was so low that the canoes had to be dragged most of the way.

The two "Sports" were tolerably dry, but the guides were as wet as the rain and an occasional "header" in the stream could make them.

All were huddled round the fire, while the steam from their drying clothes and the smoke from the fire itself had a struggle with each other as to which should be first in its flight up the chimney.

Every one seemed in good humor, particularly the lady, who was really the most cheerful one in the camp. She dried her skirts before the fire, laughed at the incidents of the trip, and, while her husband pulled off her rubber boots, made fun of my embarrassment caused by the slim prospect of giving every one a chance to sleep. The weary, water-soaked men around her drank in her jolly humor, for there was a dryness about it that seemed to counteract their damp condition. It is wonderful what an electric 
effect a handsome, healthy and well-built woman can produce upon a bunch of travel-tired men, especially if she be an independent specimen of her sex-that is, one who is willing to shoulder her share of work and privation, and ask no odds on account of her womanhood.

After some discussion of ways and means, a corner of the cabin was curtained off for the lady, while the guides spent an hour in rigging up a tent outside for themselves and in getting some dry underclothes on in place of wet ones.

Bedtime came and the party turned in. By midnight everything had quieted save the rain that came down the wooden chimney and sputtered on the burning logs. The silence, too, was somewhat interfered with by a choir of snorers-or rather two choirs, for truth compels me to say that the melody was not confined to the tent outside. Who the choristers were in the cabin, I can't say; I don't think the lady was one of them, for I heard no soprano notes.

Next day the newcomers started out to explore the lake and its surroundings, and to try the artificial flies on the trout. They had brought a tent with them which was set up some distance from ours, and to which they removed. It was a nasty night, so all stayed indoors. At half-past three in the morning the startling cry of "Fire! fire!" awole me. The inside of the cabin was ablaze. The clothes hanging 


\section{A FIRE-AND-WATER MEDLEY 159}

on a line were sizzling, and two rubber coats that were burning gave out a suffocating odor. The cabin was as inflammable as tinder, its roof being of birch bark and full of resinous oils. The wooden chimney was now on fire from top to bottom, and the sides of the cabin a hissing sheet of flame; so there was no time to do much thinking.

I rushed out into the rain in bare feet, grabbed two buckets of water that fortunately stood near the camp and handed them to my companion, who was still lustily yelling "Fire!" I then ran to an outside camp-fire, where I found a kettle full of water. The guides in the meantime had been aroused and were now throwing the water upon the sides and roof. Their efforts were successful, and the fire subsided almost as quickly as it had started.

Since this incident I am not surprised to learn that there are numerous fires, with many casualties, every fall and winter in these dangerously combustible buildings that are in use all through the lumber district of the province of New Brunswick. Not many years ago three young men were roasted to death in just such a fire trap as ours, and not one of the three had been able to reach the door before death overtook him. One of the victims had apparently gotten up from his bed of boughs, made a step toward the door, and then stumbled and perished in the flames. The other two in their agony had tried to get up, 
but had fallen back again. Their bodies were found, burned to a crisp, and sent home to their friends for burial.

Since that night I have had a decided preference for lying outside the camp and on the ground-anywhere rather than in a wooden cabin with a wooden chimney and a wooden fireplace. Let me thank God, for I have cause, that in His kind Providence $\mathrm{He}$ thought fit to save me from a fearful death. 


\section{$A$ Day in the Big Woods}

It was my deer.

-JULIUS CESAR.

ON one of our hunting trips through the wilds of liaine we had a series of three camps, and I think it will add interest to my tale to describe these minutely before beginning it.

The lower camp is pitched upon a ledge of rock commanding a delightful prospect, embracing a small, circular lake in front, with an open, grassy bog on its sides and back of it, and a thoroughfare leading out of the little lake to a large one, eighteen miles long, some two miles below. We named this camp "Lookout Point." Back of the camp, and three-quarters of a mile away, there is another small lake, long and irregular in shape, with a muddy bog at the mouth of it, where the busy beavers have built one of their characteristic dams, which, my guide tells me, contains two adult beavers and three young ones. How he became so well posted in the number of sprouts on their family tree, I can't say; but surely there were beavers there, for we saw evidence of their fresh work each morning that we inspected their dam. Their house was some two hundred yards away from 
their dam and pitched in a piece of deep, spruce woods. It was close to the water and connected with it by various tunnels which the beavers use when the lake is frozen over and they have to forage for their food and exercise.

The region around "Lookout Point" camp is well cut up with moose and caribou tracks, and, as it commands the two little lakes, is a very desirable camping spot. Four miles up the stream which runs into the first little lake, is a good-sized sheet of water about three and a half miles long and perhaps a halfmile broad. Here we pitched our main camp and built a cabin of bright, clean logs, flanking it on one side with a commodious cooking and dining-room. This we furnished with a modern cook stove and all its appliances, not forgetting plenty of shelves for the dishes and utensils.

In the cabin itself we had a small stove, three bunks to sleep in, and plenty of room to "loaf" and take our ease. Within two minutes' walk from this camp is a rocky point overlooking a secluded cove where the deer come out in the early morning or at sundown to drink and play upon the sandy shores. We made this our middle camp, and it was here that we kept all our stores, as well as our surplus clothing. Six miles up the stream that feeds this lake we had our end camp, which we called the "Dam Camp," because it controls a dam a quarter or half a mile further up-stream. 


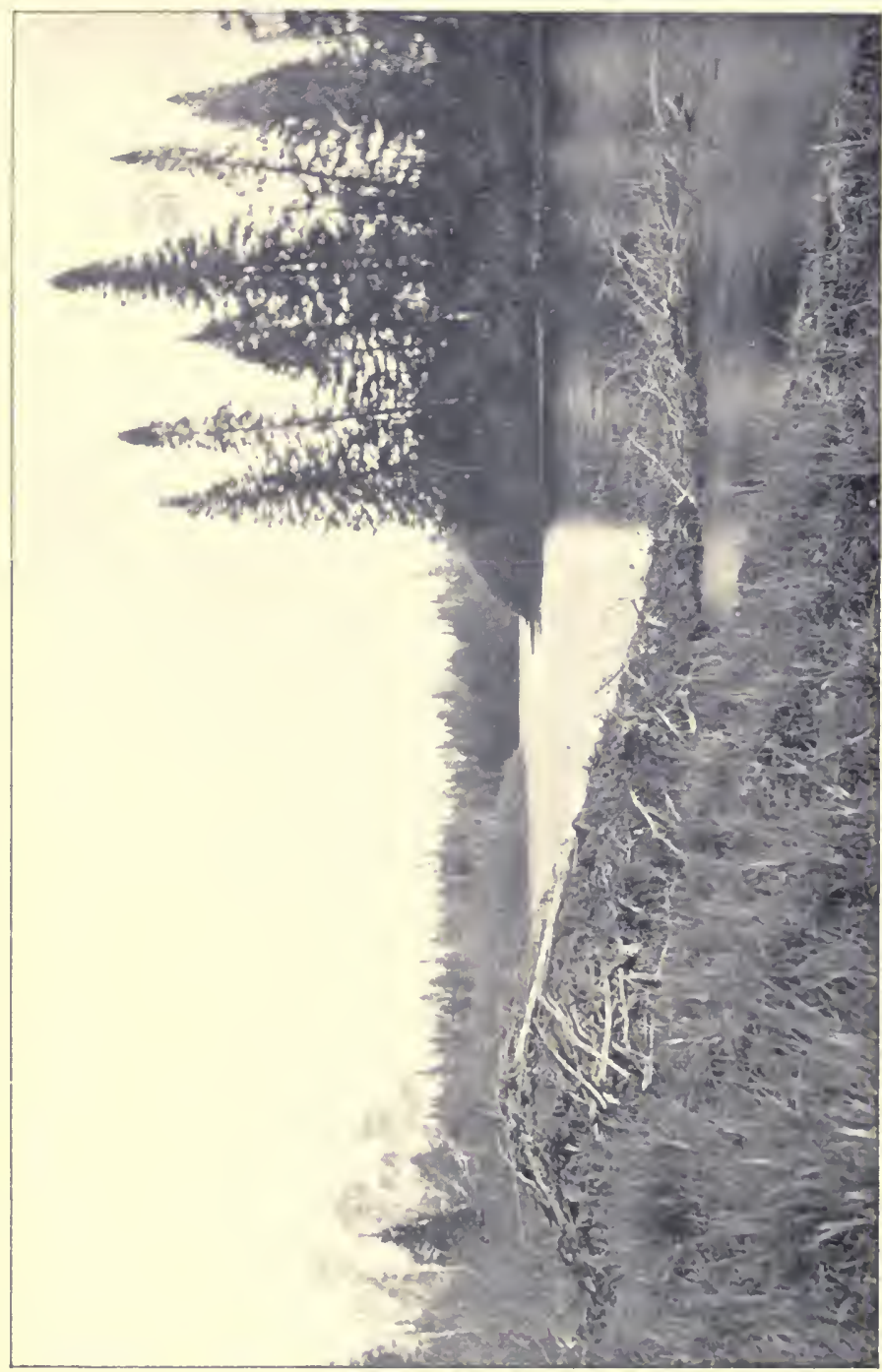

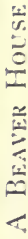




$$
\text { and }
$$




\section{A DAY IN THE BIG WOODS 165}

This dam was formerly used by the lumbermen to store enough water to enable them to rush their logs down the lake below when the snow melted in the Spring. For a couple of miles above the dam the backing up of the water in former years had killed all the trees near the banks of the stream and in their place alder and hazel bushes had grown up in semi-tropical profusion. Here, among the swale and wire-grass, the deer and moose often spend their time, feeding at night and taking their rest during the day. On one side of the stream, where the grass was tall enough to almost hide a man standing upright, I saw one bed that a moose had occupied the night before and more than twenty in which the deer had been lying.

Two miles away from this big-game Elysium is a dry bog frequented by caribou and to which, for that reason, we gave the name of "the Caribou Bog." It is not to the bog, however, that my story relates, but to the "Dam Camp" and its environments. Now I warn the reader that he must not look for anything in my story to shake his nerves and make his hair stand on end, porcupine-fashion, although the sharpquilled animal may and does figure in it to some extent. No, my tale is merely a recital of what any man may see and on any day-if he chooses to visit the region of the Dam Camp and keep his eyes open.

One morning, a little after five o'clock, I started up the brook to take a look over the dam. It was not 
quite daylight, and objects, eren a short distance away, had an undefined and hazy look. A few yards up-stream I saw what I took to be an animal of some sort going slowly along and keeping about the same distance ahead of me. What it was my eyes were unable to tell me, further than it was very round and very dark-looking. Sometimes it would walk on the stones in the brook, as if afraid of getting its feet wet, and where there were no stones to step on it would take to a path in the grass along the brook. After straining my eyes awhile I decided that the creature was a young bear and I was on the point of shooting him, when it occurred to me that if it were a "cub" the mother couldn't be far away, and it would be the better plan to watch for her, shoot her, and then capture her offspring alive. In the meanwhile the animal was walking leisurely along, turning around occasionally to take a look at me, but seeming to be in no wise alarmed.

The day now began to dawn and objects about me to grow more distinct and appear in something like their proper shape. I turned my eyes inquisitively in the direction of my cub, but there was no cub there, nor any other animal that looked like one. I had made a singular mistake which it took the daylight to rectify. A big porcupine now stood in the cub's place, staring at me with quills erect and a "hands-off" confidence in his prickly armor that amused me. In a 


\section{A DAY IN THE BIG WOODS 167}

moment or two he began rolling himself into a ball, as if to prepare for battle, but when he saw I had no intention of making an attack, he unrolled himself and waddled along beside me until we reached the dam, under which he crawled, perhaps to take a rest and sleep. Of course I laughed at my mistake, and made all sorts of excuses to my sportsman's self. But excuses were of no avail. The thought would creep to the top of my mind that there must be a screw loose in a hunter's optics or in his education if he doesn't know a bear from a porcupine.

My stomach now began hankering for its breakfast. I looked about me for some kind of game that might make a foundation for it, but finding none in sight I baited a fishing line, that $I$ always kept there, made a few casts and caught enough fish for a comfortable morning meal; then I returned to camp, where the cook dressed and broiled them, and with the breast of a fat, plump partridge, killed the day before, I managed to satisfy my inner-man. Then, at a few minutes after seven, I started for the Caribou Bog.

On entering the road which begins at right angles from the brook two deer bounded out of the grass into the woods; they were both does. A half mile further up a good-sized buck jumped out of an old logging yard and disappeared in a jiffy. It now began to drizzle a little, causing the noise made by walking to be almost imperceptible, else why should that most 
crafty of all wild animals, a fox, be ambling on ahead of me in the road, unconscious of the fact that there was a man behind him with a 40-82 rifle? I thought to myself, "Perhaps Reynard has had a good night's hunt, and captured and eaten a partridge or two with half-a-dozen field-mice by way of dessert, and now he's contented and tired and on his way to his habitation and his bed.

I was too near the Caribou Bog to fire at him-the noise might alarm the game-and so I walked on behind him until my foot broke a.branch. He heard the sound and the next instant I saw a streak of yellow color flying through the trees. It was the last appearance and exit of Mr. Fox. I watched for a moment in the direction of his departure and fancied I heard the pounding of a buck's forefoot. Just then the sun shone out bright and warm and I stood for a fow minutes enjoying its rays and listening. The pounding continued, but I finally concluded that it came from a giant woodpecker hammering at one of the trees. At this moment, turning my face and looking up the road, I saw something that caused my heart to beat a rataplan. Not thirty feet away and coming toward me was a monstrous cow-moose. She was apparently wrapped in thought, possibly of her last night's happiness when she thrashed through the alders and meadow grass with her lover-him of the towering antlers. There was a small sapling bent 


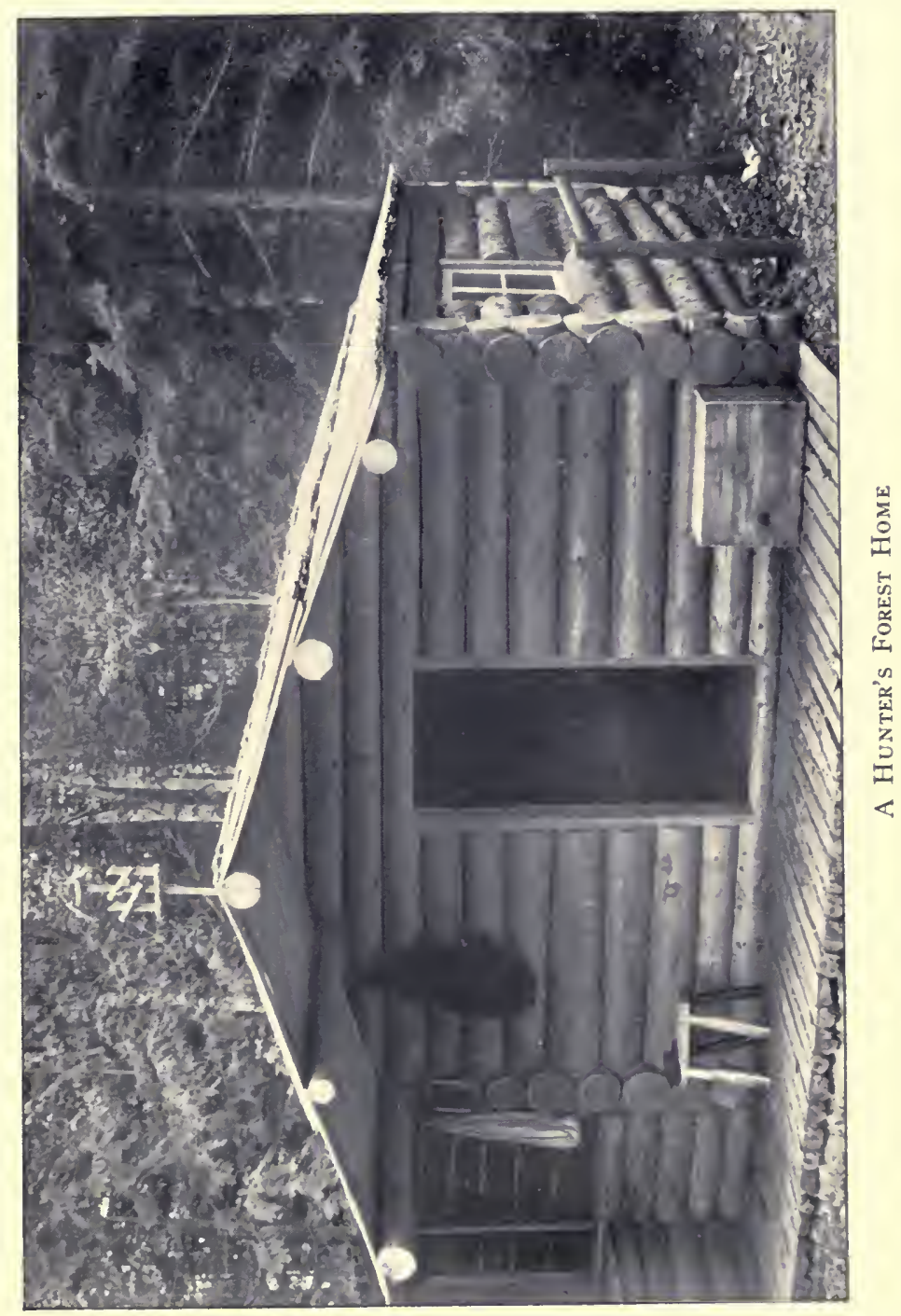





\section{A DAY IN THE BIG WOODS 171}

down over the road, and its leaves, at the angle she was carrying her head, prevented her from seeing me. My first thought was that she might be followed by the bull, and I therefore made one step to the right. At the sound of that one step she stopped. She couldn't see me, because of the sapling, and I couldn't see her now, because the trunk of a tree intervened. And there we stood, listening to each other, but neither of us moved. Minute after minute passed and in the meantime I did a heap of thinking, standing there with nearly my whole weight on one foot until the strain became unbearable. Yet I dare not put the other down for fear it might crack the dead branches which lay there and the noise of it be fatal.

I calculated that in all probability the bull had come along the road with her, and had stopped a little way behind. If this were so, I would soon have the pleasure of seeing two moose instead of one. But my calculations were all out of joint. The minutes passed away and still the old cow stood there, but no bull made his appearance to console me. At last she saw me, and when she did, she turned a little to the left and entered the woods, slowly and quietly, and without showing the slightest sign of alarm.

Her tracks proved her to be a moose which had been prowling around the dam for several nights past. After this episode I reached the Caribou Bog, stayed there during the forenoon and thence went back to 
camp for dinner. On returning to the bog, I crept into it very carefully, as the breaking of some dry branches assured me the caribou were feeding there, and spent the afternoon in watching the cows as they passed and repassed my place of concealment. As for the bull, the "King of the bog," I saw nothing of him, and giving up all hope of seeing him left the bog at a quarter to five and started for the camp.

I was walking briskly along - the weather had grown cold enough to make briskness desirablewhen I heard a noise in an old logging yard opposite to me. Now, a hunter's ears have need to be sharp, and mine were sharp enough to tell me that either a moose or a deer was behind that noise and to be prepared for him. I looked around and, sure enough, a buck was there and making for the woods with leaps that were mighty long and mighty full of lightning.

I had barely time to say to myself: "Thomas, this is thy deer. Come now, try thy hand at a flying shot."

To cock the rifle and bring it to my shoulder was the work of a second, and at that particular second the deer was springing over the last log that lay between himself and safety. I saw his "flag" fly up as he took the leap, and fired at the very instant he disappeared on the other side of the log. I supposed I had missed him; but no; when I reached the log, there he lay behind it, convulsively giving his last 


\section{A DAY IN THE BIG WOODS 173}

kick. The ball had struck him near the tail and ranged through the body, coming out at the foreshoulder. He was a four-year-old buck, and as fat as he well could be without melting. I dragged him into the road, went down to the camp, had supper, and then, with a lantern and the guide, returned to where he was lying, opened and dressed him and taking the hind-quarters and saddle reached camp at 8:30 P. M.

I was in bed at nine, and do you wonder that I slept soundly that night? Do you wonder that I knew nothing of the passing hours? Nothing of the camp-fire burning in front of the camp? Nothing of a deer which approached our fire close enough to inhale the strange scent of burning wood, and then rush wildly away, whistling as he ran and alarming his kindred far and near? No, reader ; my psychological and acoustic machineries were both at a standstill. My brain was too drowsy to dream, and my eardrums had lost all their cunning appetite for soundseven for the snore of my Canadian cook. You have never heard, and perhaps have no desire to hear him; but I can assure you he is an expert in that line, and knows as much about scientific snoring as he does about scientific cooking. When he turns on his back and gets his fog-horn under way, its spasmodic grunts and snorts and roars would probably drown the noise of a sawmill. 


\section{A Dead-water Vigil}

Couching, head on ground, with cat-like watch.

-As You LIKE IT.

VIGILS, as the reader is doubtless aware, may be of all sorts and sizes, and I will now try to entertain him with a short story of a long one. It is of the "deadwater" variety, and if he hasn't had enough hunting experience to know exactly what a "dead-water" is, I will tell him. In a big-game country when a stream widens out to several times its normal breadth and then flows so lazily that the current is almost imperceptible, that part of the stream is known to the hunter as a "dead-water." It is a place full of attraction for him, and for the best of reasons. Its banks are usually covered with a growth of rich grasses and low bushes, while near the shore various plants of the lily-tribe lift themselves above the water and nod their tops to the breeze. If the location be secluded, as it generally is, and there be enough growing timber around it to safely shelter the approach of the moose and the deer, the hunter is pretty sure to find their tracks along the shore and in the soft clinging mud. Such a place is a veritable paradise for these shy creatures. Here the antlered moose delights to spend his 


\section{A DEAD-WATER VIGIL}

early mornings wading and drinking and nibbling his breakfast from the tops and stems of the lily-pads. Here, too, the deer gluts his or her appetite, but confines it to the tender shoots and leaves of the hazel and alder bushes.

Hence it is that the "dead-water" has a magnetic hold on the hunter. The top-notch of his ambition and desire is to catch the glimpse of a bull-moose wading the stream and indulging here in his lily-pad breakfast. Then, if the glimpse be long enough to allow the "sport" to cock his rifle and bring it to his shoulder, the bull will probably finish his breakfast; although the "finish" may not be over-pleasant to his antlered majesty.

Some four miles from Lake Nictau-the source of the Tobique River-lies a favorite resort for game. A spotted trail leads to it, running over two or three good-sized ridges and in the most erratic fashion. I have made at least a dozen trips over that trail and therefore am familiar enough with it to know of what I speak. Who the man is, or was, that "spotted" the trail I am not prepared to say, but I do say that the crooked, crab-like manner in which it climbs up and down and over those ridges is strongly suggestive of one thing-and it relates to the man himself. Before taking up his little ax and starting on his spotting task he must have gone to Sir John Barleycorn for instructions. 
On my last visit to this place I saw a large cowmoose and a two-pronged bull quietly feeding down the stream. I came close to them without their knowing it-so close, indeed, that I could have slaughtered both, and with a single bullet. But I had no desire to trouble either of them. The bull was too young and too small to fill my fancy; and as for the cow, her sex made her sacred and as safe from the range of $\mathrm{my}$ rifle as a babe at the breast of its mother. After watching them awhile and grumbling at the bull for not coming into the world a few years sooner, I saw them go leisurely on their way down the stream and then pass from my sight.

To the guide and myself this incident was full of meaning. It gave us reason to believe that a bull of riper years-the sire, maybe, of the youth we had seen-might be wandering about somewhere in the neighborhood, and therefore we determined to spend a few nights there for the purpose of making his acquaintance. My guide had brought blankets with him, and spreading these under the shelter of some alder bushes and close to the water's edge I lay myself down, but not to sleep.

The night was cold and clear. There was no moon and the darkness was intense. And there under the alders I lay with " head on ground," opening wide my ear-gates for the free entrance of every sound, let it come from whatever quarter it might. Whether the 


\section{A DEAD-WATER VIGIL}

eyes of a cat would have helped me to pierce the darkness I know not, but my own were certainly of little use for that purpose.

When the sun dropped behind the ridges and this duskiness began to creep over the face of Nature, it seemed as if the thoughtful dame had given all her creatures--except her noctivagant rakes-quick notice to finish whatever task they had on hand and get to bed. Black ducks and cranes and birds of every feather, save the owl's, all were in a skurry, and each in a full-tilt-race to be the first to reach his roost. The red squirrel heard the notice, stopped his chatter, and was soon cuddled up with his head pillowed on his bushy tail.

To the hunter these red squirrels are something of a nuisance. They abound in this section, as they do in every northern forest, and keep up a constant chattering, mingled at times with a sort of ventriloquistic laughter which is very amusing to the hunter-if he is not on the lookout for big game. But when he is stealthily creeping along, picking out a soft spot to place his foot where it will make the least noise, and halting and listening at every step for some sound which may tell him that the animal he is looking for is not far away, then the laughter of the bushy-tailed rascal is not so amusing. It is just then, however, that the little fellow delights to get in his mischievous work and he does it most effectively. He will make 
for a tree, dash to the top of it and then down again, dancing over the logs that may be in his way but keeping a constant eye on the hunter. Then perbaps he will stop his gambols for a moment to bark and chatter at the "sport," winding up with a peal of derisive cachination that sounds-to the victim's imagination-something like: "What do you want here? You're a queer-looking chap, anyway. Why, you've got no tail! Here, I'll lend you a bit of mine!" With this generous offer he will skip out of sight, and the chances are a hundred to one that if a deer or a moose or a caribou has been within earshot of that laugh, he, too, has done some skipping of the same sort.

And now to return to my vigil. I heard a cowmoose step softly into the water, drink her fill and then as softly leave the stream and depart from my neighborhood. The next morning we saw by her tracks that she was a cow, and the same old cow we had seen in the daylight.

The dead-water, upon whose side I was couching, lies in a wide hollow. On either side of it rises a tall ridge covered with trees of spruce and white birch, and whatever sounds are made on the one ridge are echoed from the other. I heard the bark of a fox on my side of the hollow, and in a moment or two an answer came from the other side; and then another bark and another answer, and these kept duplicating until it 


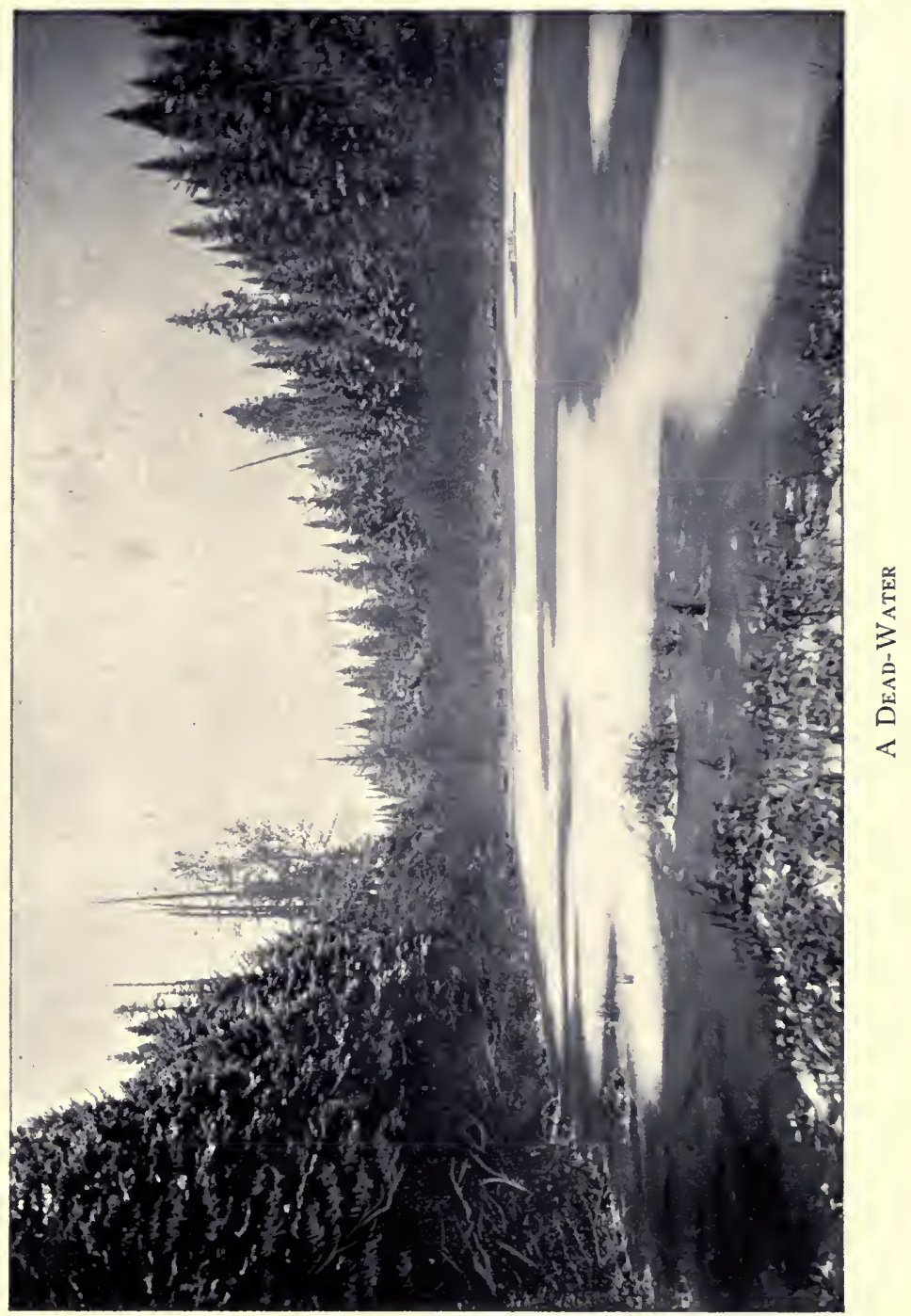




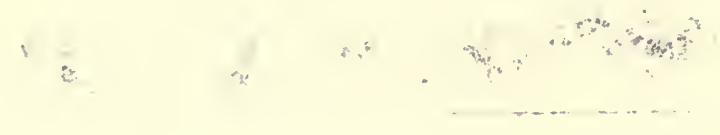

i

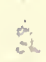




\section{A DEAD-WATER VIGIL}

seemed as if the tribe of Reynard had sole possession of the ridges. Their music was not altogether pleasing. The bark of a fox is sharp and snarling and the melody made by a chorus of them will out-snarl and out-reach any amateur quartet that ever punished the ears of an unoffending audience.

The night dragged on. I grew sleepy, tired and hungry, while my spirit was depressed and my patience worn out by the tedious length and depth of the darkness. I will say here-and I am rather proud to say it-that I have no temperament, nor any other quality that fits me for a comrade with the owl; at least, none that could rob me of my taste for the light of day. Therefore, if the bird of ill-omen insists upon shrieking his "songs of death" he must do it in other company than mine. I'll have none of him. But here is a question that may stagger the wit of the Shakespearean reader to answer: How, in the name of all that is incredible, did the great dramatist discover merriment in the note of an owl? Yet he did so, unless his "merry" epithet in Hiems' song, at the end of Love's Labor's Lost, be one of his gibes:

" When blood is nipped and ways be foul, Then nightly sings the staring owl

Tu-who!

Tu-whit! Tu-who! A merry note While greasy Joan doth keel the pot."

No, no, William, my boy ; though there may be much 
wisdom in the stare of an owl, the merriment in his song is rather too funereal to tickle the ears of Hilarity.

There are some who believe the owl to be "wellheeled" with weather-wisdom; a second edition of Old Probs in feather binding. They say that when he chooses a tree by the edge of a stream or lake from which to shriek his melancholy forecast, there is rain coming and plenty of it. But when he moves his music stand away from the water and fixes it upon the ridges, fair weather is close at hand. I must say that my own experience can partially endorse him as a weather prophet. During my vigil he perched himself upon a tree near the water's edge and near enough to my watching place to give my ears the full benefit of his melody. His prophecy came true, for it was quickly followed by a hard rain accompanied with a hurricane-like wind.

The owl, however, was not the only forecaster of the storm. Before it broke, and in the midst of a dead calm, I heard the fall of a tree some two hundred yards away. "Do you hear that?" said the guide. "There's going to be heavy weather. Whenever a tree falls in a calm like this, there's a big storm coming, sure."

Now, I knew that Nature sometimes foreruns her storms with a calm, but did not know that she was in the habit of mixing it up with the fall of an old tree. 


\section{A DEAD-WATER VIGIL}

If she is, it is a curious habit, and being curious let us consider it curiously. She has endowed her trees with life, why then should she not have given them the needed senses to make their lives worth living? And she has done so, if we can believe those ancient writers who have made the subject their study. They say that all vegetals belong to one sex or the other; that they know what love is, and are as liable as mortals to become the victims of its fury. Claudian, in referring to Cupid's sway in the vegetal kingdom, says: "Trees are influenced by love, and every flourishing tree in turn feels the passion. Palms nod mutual vows, poplar sighs to poplar, plane to plane, and alder to alder." The palms, however, seem to be the most susceptible. Constantine says: "You might see two palm trees bend affectionately toward each other and stretch out their boughs for an embrace and a kiss;" and Galen avows that they "Sometimes become sick for love and pine away and die."

Now if all this be gospel, why shouldn't a tree have enough instinct to foreknow the coming of a storm? Indeed, if it had lived long enough, it might have no need of calling on the aid of instinct. Suppose its hoary top had battled with the storms of a hundred years or more, wouldn't the old tree be likely to have a rheumatic limb or two? Wouldn't it have as good a title to the "rheumatiz" as any that antiquated humanity could boast? And wouldn't the twinges 
furnish the same foreknowledge of bad weather? You may admit all this and still ask: "But why should the old tree give up the ghost and tumble over at the approach of what it knows is coming?" $\mathrm{Ah}$, reader, you must go to Nature herself for an answer to your question. It may be that the tree had lived its allotted time and knew it. It may be that its foresight saw two alternatives-to tumble over or be blown down. It may be that the latter would have been too great a blow for its pride, and therefore it embraced the former. These, of course, are only "may-bes," and it may be you will put them on your list of "mayn't-bes." But enough of this digression.

I have said that my spirits were losing their elasticity under the pressure of the darkness. Possibly you think that an enthusiastic hunter should be able to bear with complacence the incidental plagues of his trade, however unbearable they might be to other people. Perhaps he should, yet I don't hesitate to aver that a fruitless watch through a stretch of darkness-if the stretch be long enough and black enough -will cool the enthusiasm of any "sport," eren though it burn with the fervor of Nimrod's.

But the end was near. A faint glow began to break the gloom and light the eastern sky. The red squirrels were already awake and busy in stuffing my ears with their bark and chatter; the black ducks had 


\section{A DEAD-WATER VIGIL 185}

left their water roost on a forage for breakfast; while the cry of a loon, flying over Nictau Lake, and miles away, could be heard hailing the coming of the morn with its unearthly notes: "Ha! ha! Ha! ha!"

* * * * * * * *

My dead-water vigil was over. The sun peeped above the ridge-tops and saucily threw his glances across my bed of boughs. Hiding my face from his gaze, I lay me down to sleep and dream and treat my slumbering eyeballs to a scene that in their wakeful moments was denied them: "A bull-moose at his breakfast table." 


\section{Dog-day Advice.}

This is hot weather, gentlemen.

-HENRY IV.

A BIG city, in the midst of the dog-days, is a big cook-shop-a huge grill-room, as it were, wherein the can't-get-aways are flopped on the gridiron of Old Humidity and cooked in their own grease. Man, of course, was never born to be broiled, and common sense says he will avoid the process if he can. If he can't get away from the Old General's gridiron, he is somewhat excusable in bowing to the inevitable and should endure it philosophically-if the fat be not entirely grilled out of his philosophy.

But, strange to say, there are some who can get away and don't. What their reasons are, 'twould be hard to say-unless they expect a long spell of hot weather in the next world and would season themselves for it in this.

Now, whether these fellows be sports, or merely incogitant chips from the common block of humanity, a bit of advice can do them no harm, indeed it may do them a deal of good, and will-if their seasoning theory doesn't stand in the way of their following it. Here it is : 
When their mind and body are both "knocked out" in their dog-day rounds with Old Sol; when they become tired of dodging flies and mosquitoes and perspirations and sunstrokes; when lemonades and sodas and mint juleps and palm-leaf fans et $i d$ genus omne, have resolved into vanity and vexation of spirit; then is it high time to pick up their duds and over-roasted remains and get. Get where? Well, let them try a water-trip to St. John, New Brunswick. The transition from their cook-shop to the ocean air will be magical. The sun may still be hot, but only pleasantly so, for the cool and salty breezes temper its rays and make even an overcoat a welcome addition to comfort. I speak knowingly, for my younger son and myself once took the trip preparatory to making a sporting pilgrimage to the headwaters of the Nipisiguit River, in search of the giant moose and his partner of the forests, the caribou, and where we also hoped to interview one or more bears, and try the luring qualities of our artificial flies on the square-tailed trout and his big relative, the salmon.

This wilderness of swamp, bog, forest, river and lake is a delectable one for the hunter, and to reach it he must travel a whole day by rail, although the distance as the crow flies is less than a hundred miles. Then comes a vehicle ride of thirty-five miles. (The ride was formerly over an old lumber road and in an 
old lumber wagon, consuming some twelve hours' time. Now there is a good road and the conveyance is all that could be desired.) The next day, if the weather and the water both are fit, he takes to his canoe and gets over as much of another thirty-five miles as his muscle can master. If the water be not fit, he must walk and tote his canoe and stuff. This must needs be hard work-at least for the guide-and yet it is only the beginning of a month's or six weeks' toil. But he shouldn't be discouraged and won't be if his veins run with the blood of a sportsman. The toil may fag his physical framework a little, yet he may find in it an exhilarating oil for his metaphysical machinery.

And now to return to the city of St. John. It is scrupulously clean-indeed, it couldn't be otherwise, being situated upon high hills and constantly windswept either from the ocean or the spruce forest of the valley of the St. John. While the Union Jack that floats from many buildings and from the shipping in the harbor speaks plainly of the city's nationality, yet a great portion of those who travel its streets are subjects of Uncle Sam. St. John's business men all have a high regard for the depth of Sam's pocket and look upon it as unfathomable. His dollars, whether silver or paper, are deemed quite as good as their own, and nothing is said about exchange.

According to the custom's rule we had to pay a 


\section{DOG-DAY ADVICE}

deposit upon our rifles and camera (this was refunded when we finished our hunting trip and returned to St. John), but the officer who demanded the deposit did it in such a gentlemanly way we were almost under the impression he was doing us a favor.

New Brunswick must surely gather in a goodly store of greenbacks from the sale of hunting licenses. Every would-be hunter from outside the province is required to pay thirty dollars for the privilege of hunting within its limits; and in return for this he not only gets his hunting privilege, but is protected from the pot-hunter. The open season commences September 15th, whereas in Maine the open moose season starts October 15th, and caribou cannot be killed there now, nor for five years to come. Hence it is that aspiring Nimrods make their hegira from all parts of the land and encompass the hunting grounds of the valley of the St. John, the Restigouche, the Nipisiguit and the Tobique Rivers. All go into camp with the proverbial hope of the hunter. But the result is something of a lottery - all cannot be successful; and like other lotteries there are plenty of blanks. 


\section{A Tale of Gallantry and Hunger}

Upon my life 'tis true, sir.

-TinoN of ATHeNs.

IT was a rainy, cold and disagreeable morning when my son and myself left St. John, N. B., for Nictau Lake. We had donned our heavy underwear when we started-6:25 A. M. - but when we reached Perth Junction on the St. John River at two o'clock the sun came out and ran the thermometer up to $93^{\circ}$ in the shade. A return to light underwear became necessary for our comfort and we looked about us for some place, in or around the little station, where such a change could be made with decency. We saw none. However there was a forty-five-minute wait before the train started on its way up the Tobique Valley, and I made use of the time in hunting up some spot secluded enough to hide a bashful man from the outside world while he changed his inside toggery. Walking down the railroad track I came to a gorge in a high hill and behind its shelter accomplished $\mathrm{my}$ toilet, but not without some shivering; for, though the thermometer stood, as I have said, at $93^{\circ}$ in the shade, the temperature in that gorge was very different. A chilling, goose-flesh wind scurried through 
it and I was glad to get out of its shadow and into the sunshine.

When the train backed down to the station, preparing for its start, I found on the platform a Bangor taxidermist whose reputation in that line is alnost national. He was bound for nearly the same hunting ground as myself, as was also a noted salmon fisherman with his two sons. The train, which should run every day-for it is so nominated in the bondran only every other day, and was made up of freight cars, gravel cars and a couple of passenger coaches. Among the passengers were a number of Indian guides, lumbermen, a sprinkling of sportsmen, and last, but not least, some very pretty women. The schedule time from Perth to the end of the line is two hours lacking five minutes. As the distance is only twenty-eight miles, it would seem that an engine with any ambition in its piston rod ought to be able to "get in on time." But this particular engine is not particular whether it does or does not meet the schedule's demand, and the common report is that it does not.

When we were about half-way on the trip a comelylooking young woman told the conductor she wished to get off. When he stopped the train, it chanced to be on a high embankment at the bottom of which ran a road, with the Tobique River just beyond it. The young woman now left the car, the conductor helping 
her down the steps from the platform. I looked from the car window and saw her standing there with a huge telescope in one hand and a bundle of something in the other. She evidently had a desire to get down that steep embankment, but, laden as she was, lacked the courage to try it. None of the train hands showing any disposition to help the young lady out of her dilemma, I jumped down the car steps, took her telescope and bundle, told her to wait for a moment, then scrambled down the lill with my load and deposited it at the bottom. Then climbing half-way up again I beckoned to her to come on. She came, and locking arms we commenced our descent. Around like a top we spun, sliding and slipping and pirouetting till we reached the bottom. The performance seemed highly entertaining to the passengers, who choked the car windows with their heads, grinning their delight and shouting their applause when it was over.

I have said the young woman was good-looking, and youth and beauty are sharp goads to a man's gallantry; but I don't wish it to be inferred that they were the only spurs to mine. Had she been as old as sin and as ugly as its father, and this accommodation train accommodating enough to wait for me, I might perhaps have further shown my gallantry by toting her baggage to its destination. And then perhaps I mightn't. However, she picked up 


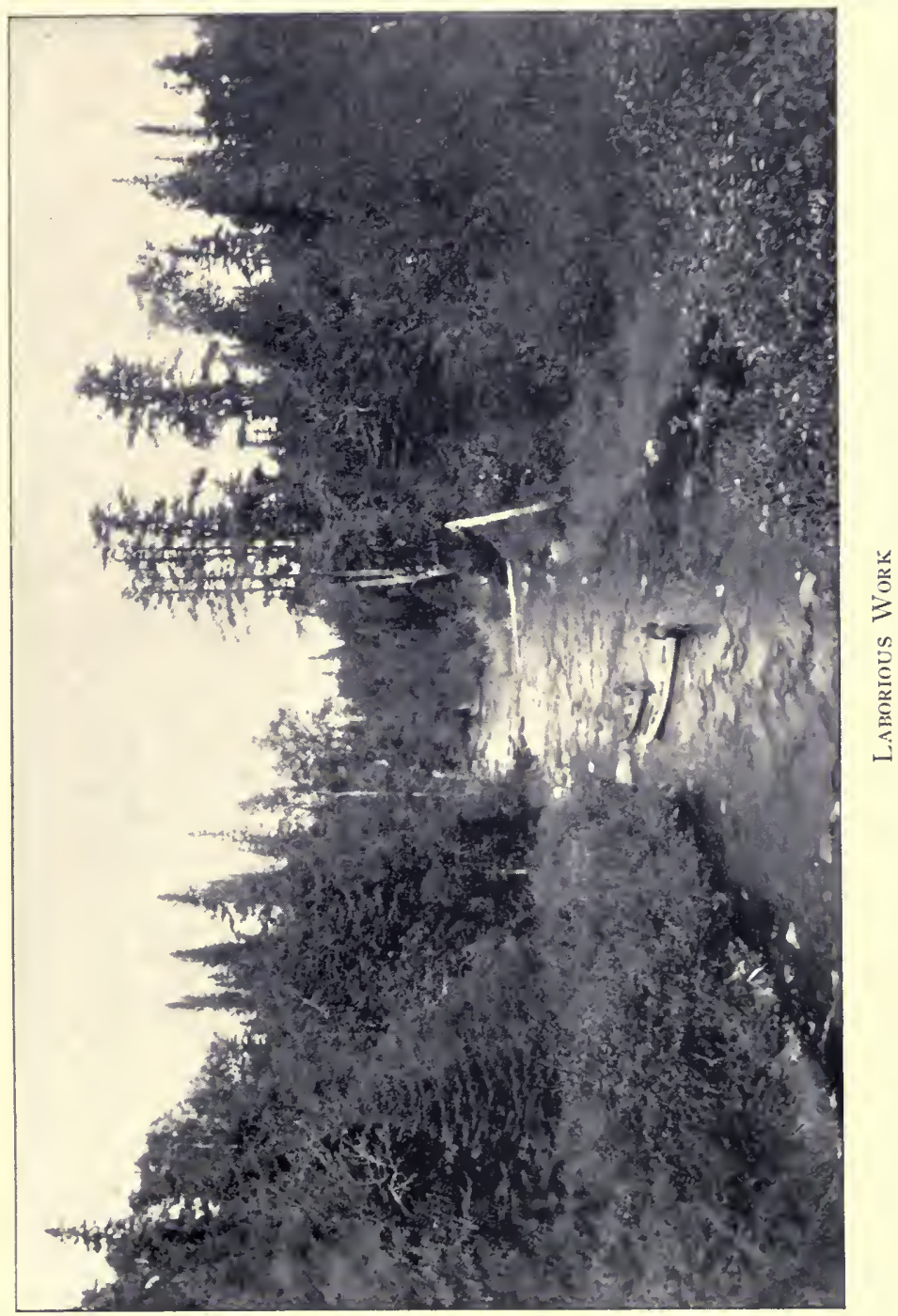



her telescope and bundle and started for her home. I watched her as I stood on the rear platform of the back car and saw her step on the porch of a cozy-looking house. Two chubby tots ran to meet her, clapping their hands and puckering up their little mouths for a kiss. Before obliging them she turned, looked back at the train, waved her thanks and a good-bye to the man who had helped her in her time of trouble, and then, like "Ships that pass in the night," we parted.

At Plaster Rock we took a wagon for a night's ride to Reilly Brook, twenty-eight miles up the river. We started at quarter to $8 \mathrm{P}$. M. reaching the Brook at 1 A. M. At five we were off for a wagon trip to the Forks-a distance of seven miles-and we enjoyed it. The air was "nipping and eager"; myriads of spider webs were spun by the roadside and hung from the bushes, trees, and logs, coated with the night frost and glittering in the morning sun like gems in a jeweler's window.

At the Forks we were joined by our canoemen and also the chiefs of the hunting camps to which we were bound. At quarter to eight we left the Forks, taking to our canoes which were to be poled up the river to Red Brook-a distance of twenty miles. The stream winds in a tortuous course over a rocky bed, and, as the water is low at this time of year, poling the canoes was laborious work and hard on the men. To lighten the load of my canoe I suggested-and 
it was so arranged-that I should get out and walk through the woods, meeting them further up and at a point where the road and stream met again, some two miles away. I took my rifle and started. The walking was good, and my observation, therefore, was not interrupted by any necessity for picking $\mathrm{my}$ steps. I saw about me fresh signs of moose and many indications. of caribou. In fact I became so much interested that I forgot all about my canoe and for what I was walling. I had already passed the meeting point without knowing it, and it now lay behind me a mile or more.

The road wound back over the ridges quite a distance from the river, but I thought it wouldn't be wise to retrace my steps as I might thereby miss the canoes, and therefore resolved to go on and take whatever chances might be ahead of me.

About eleven o'clock I heard rifle shots which my fancy told me were signals from the canoe party. I fired three shots in reply and waited for a response; but none came. Did my fancy make a mistake about their being signals? Perhaps; but I soon heard another sort of signal about which my fancy could make no mistake-I was getting "as hungry as the sea."

Now, a hungry stomach is a multi-sceptred potentate. Despot, autocrat, oligarch and "cock of the walk" generally, it has no ears for argument, no appetite for excuses. It has plenty of jaw, at times, but 
there is no flippancy, no circumlocution, no roundabout method in it, and when it speaks it insists on being listened to. The old poet, Homer, discovered all this some three thousand years ago and gave his discovery to the world in words of unmistakable sincerity: "There is nothing more importunate than a hungry stomach. It allows no man to forget it, whatever be his cares and sorrows." If we are to believe his biographers, the old fellow was a sound authority on the importunity of hungry stomachs. Like some others of his trade, he was bothered with one himself, and its clanors often kept him busy in scraping together enough bread to quiet them.

But let us leave Homer's predicament and return to my own. Perhaps if I had been accustomed to taking my hash in far-between instalments or none at all I might have tolerated the situation with calmness. Custom is a marvelous transmuter of the disagreeable into the delectable. "Custom alters nature itself;" and we have all manner of authority for believing the proverb to be true. That literary nomad, Robert Burton, goes so far as to declare that "Custom makes even bad meats wholesome"; and Shakespeare, too, attests its miraculous transmuting power. If then it be potent enough to transform bad meats into wholesome ones and grave-digging into a delightful occupation, why might it not make hunger in a man "a property of easiness"? Unfortunately, however, my 
custom runs in a different groove. I have been used to "eat when I have stomach and wait for no man's leisure": therefore the promise of a long-drawn interim of not eating at all was anything but pleasing.

It was now twelve o'clock. I had no matches with me, having in a very unsportsman-like manner left them in the canoe, together with my compass and other necessary things which a hunter should never run the risk of being without. But even if I had brought the matches and built me a fire I had nothing for the fire to cook.

My stomach meanwhile was getting noisy in its demands, and to quiet it I searched among the bushes with the hope of finding a few raspberries. I did find a few-some half-dozen, and, though tasty enough to the palate, I soon discovered that six of them made a slim stopper for the gap in a hungry stomach.

After finishing my "light lunch" I took up my tramp and a couple of miles of it brought me to a deserted logging camp. Its door stood invitingly open, and walking in I found a good cooking store, a few handfuls of flour in the bottom of a barrel, also a saltpork barrel. The latter was partly full of brine, on the top of which floated a little lump of fat pork. And now for a match! My kingdom for a match! I searched through that camp high and low. No Klondike digger, hungry for his shining nugget, ever searched for it with more eagerness than did I for a 
glimpse of a miserable little match. My search was finally rewarded. Turning over an old dish-rag, I discovered a box-an unmistakable match-box. I seized it with trepidation. What if it should be empty? Match-boxes have a chronic habit of that sort. I tore off the lid and found that my fears were almost, but not quite, realized. One solitary match remained alone, like Tom Moore's "Last Rose of Summer," all its lovely companions faded and gone. But one was enough and I soon had a fire burning. Then I put the flour into a pan I found upon the stove, and with a little water from the river-which flows near the camp-mixed it into a firm dough. I now put the piece of pork into a frying-pan that was hanging in the camp, and placed it on the fire. Then I formed the dough into ten little cakes, putting them into the hot pork-fat and turning them over and over until they were nicely browned. My dinner was now ready for me and I was quite ready for my dinner.

Now it is said :

\section{"The art of our necessities is strange \\ That can make vile things precious."}

Very true; but I can tell you there was no vileness about my dough cakes, although there was plenty of preciousness, and I sat me down in front of them with an appetite that a king might possibly envy; but whether he would or not, I am sure that no man, king or no king, ever squeezed more enjoyment out of his 
fantastic banquet of strange dishes, than did I out of those ten little dough cakes.

The Tobique River, as I have said, runs close to this camp, and after finishing my dinner I sat down to watch the trout in one of its pools.

The river consists mainly of shallow water falling over stony ledges, and has a rocky and slippery bottom. Yet it is hard to find a river with more enticing pools for the angler-pools profound in their depths and glorious in their crystal clearness-pools where the salmon lie in wait for their breakfast and ready to give the angler all the enjoyment he wants.

My reverie was broken up by the sound of a whistle. I looked around and saw some one coming up the road, and I was glad to see him. It was my son. He had become anxious about me, and had been piloted to the camp by one of the men. He it was who fired the signal shots, but he had heard none in return.

While we sat together waiting for the canoe to come up we saw a superb salmon fully two feet long rise to the top of the water. The youth tried a shot at him with his rifle; but I believe the salmon is still there.

And now, once more we were in our canoe and on our way up the river.

In the afternoon a cow-moose crossed the stream in front of us, but seemed to take as little interest in us as we did in her ladyship. At dusk we reached Red 


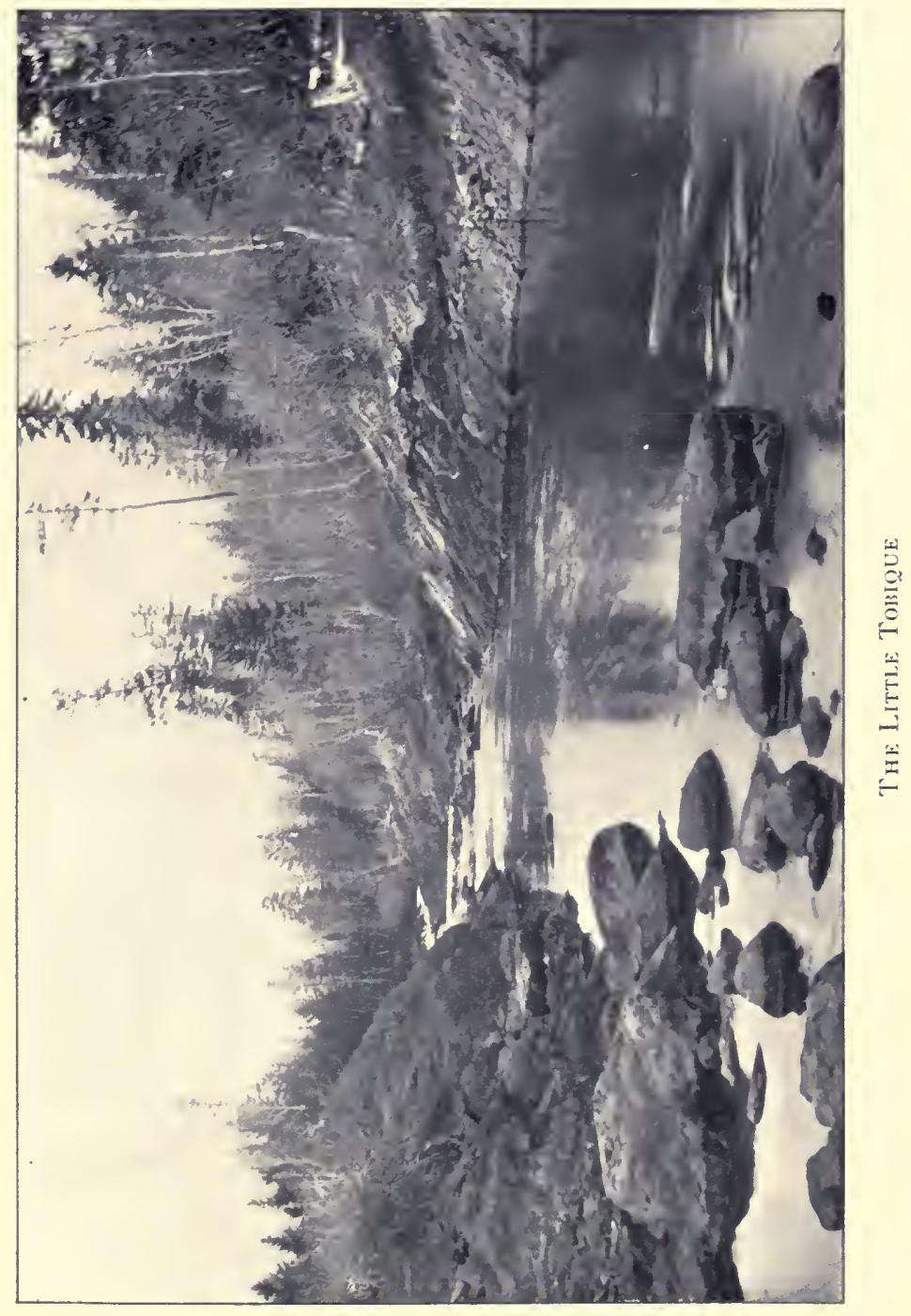





\section{GALLANTRY AND HUNGER 203}

Brook, and on Wednesday morning we were up and off again for the last part of our journey-the hardest part of all-twelve miles of poling; quite enough to try a canoeman's patience as well as his muscles.

At five o'clock in the afternoon we reached camp. 


\section{A Beardless Sport}

You are a young huntsman.

-Titus Andronicus.

Mr younger son, who has been my companion on many of my hunting trips, is as much a lover of the sport as I am; and my efforts, as his tutor, to teach his young idea how to shoot have been so successful that he now is-or thinks he is-a better shot than his father. However, he never boasts of his superiority, and his modesty in this respect is so conspicuous that I sometimes suspect that the buck fever, or its remembrance, lies at the bottom of it. This disease among hunters-I don't think I am far out of the way in calling it a "disease"-is, in one respect, very like the measles among children; every sport is liable to have it once. In its mysterious attack it gets entire control of his nerves and at a most inopportune time. He may have been standing for an hour or more, with rifle cocked, waiting eagerly for the coming of a buck that in "doubling his tracks" will be sure to approach within easy reach of his shot. The buck does approach, bounding towards him with such rapidity that the very sight upsets the nerves of the green hunter and throws his anatomy out of gear. His eyes bulge, his teeth chatter, his knees knock together, and even 204 


\section{A. BEARDLESS SPORT}

his memory is so far dethroned that he forgets he has a rifle. If he does remember it, and attempts to raise the weapon to his shoulder, there is nothing in it that is likely to do any damage to the buck, for its wabbling muzzle sends the ball either into the earth or among the clouds. Of course the buck bounds away, utterly unconscious of the excitement its presence has caused. Its instinct, however, may suggest that a buck's life is never in danger from the ball of a wabbling rifle.

'Twas in 1894 that the "buck ague" attacked my boy, who was then sixteen years of age. The attack was a severe one-quite severe enough to allow the cause of it to bound away without injury to its limbs or vitals.

We were camped on Eagle Lake in Maine, and I will now tell how the queer disease got its hold upon the youth. He was in a canoe with his guide, paddling along without any immediate hope of a chance to use his rifle. A point of land jutted into the lake, and as the canoe rounded it, the boy saw a beautiful buck standing upon the bank and gazing at the boat with wondering eyes and head erect. The animal was within easy rifle shot and should have paid a life penalty for its rash confidence and curiosity.

But it didn't. The buck fever had gotten hold of the youth's nerves, and his chattering teeth told plainly how firm the hold was. He did manage to raise his rifle, but when he tried to point it in the 
buck's direction, the muzzle began to wabble and box the compass in a fashion that boded no especial harm to the buck. In the midst of the wabbling the youth pulled the trigger and the hammer fell, but whither the ball went nobody knew. The buck was in too much of a hurry to stop and inquire, and the guide himself, who is supposed to be posted in such matters, was puzzled. He told me however, in confidence, that judging from the elevation of the boy's rifle when the hammer fell, the ball must be on its way to the polar star.

James-that is the name of my boy-was woefully chagrined over the effects of his buck ague, and though the incident occurred in '94, the passage of the years hasn't wiped it from his recollection.

I once tried to console him with the story of my own experience in that line, but the consolation didn't seem to reach the proper spot. He heard me through, and then, with aquiz in his eye, replied, "Well, father, I feel rather sorry for both of us. The man or boy who allows the sight of a buck to set his teeth on the chatter and his rifle on the wabble had better give up hunting and stay home where he can saw wood, and help his mother wash dishes and darn stockings."

It wasn't long, however, before I had cause to be proud of my boy.

The third day after his ague attack I had been on a morning's hunt, and on my return his guide came to 


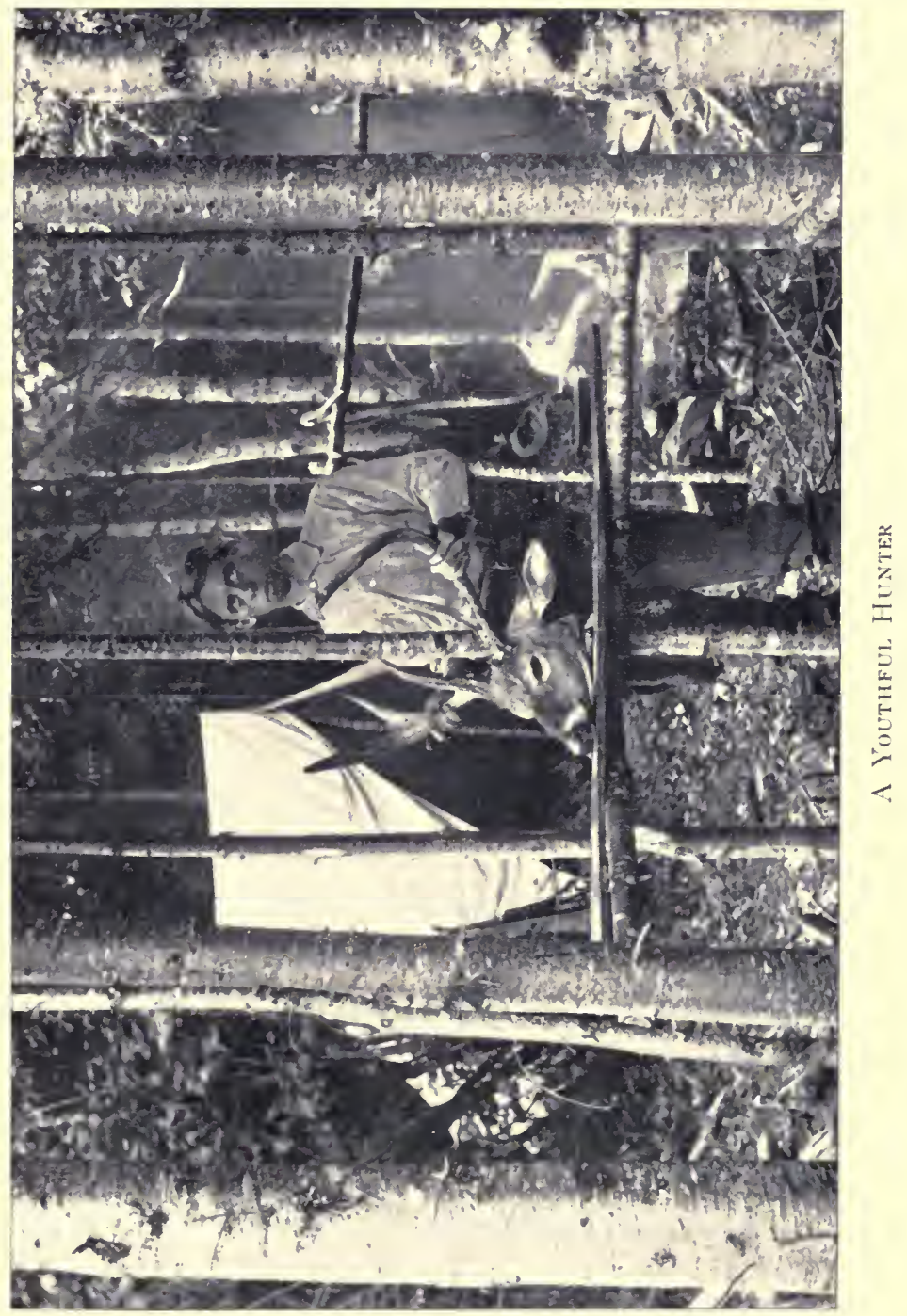





\section{A BEARDLESS SPORT}

me while I was at my dinner, and carelessly remarked, "James has killed a young bull caribou." I went on with my eating, paying little or no attention to what he said, for the simple reason that I didn't believe it. A few minutes afterwards the youth himself rushed in with a flushed face and tongue almost paralyzed with delight.

When he did get it working, he said, "Father! Father! Don't you want to go with me and see my little bull ?"

"Your little bull?" I replied. "Bull what? Why don't you finish the word, my boy? You mean your little bull-frog?"

He laughed at my doubting joke, and then led me through the brush and around a windfall to a spot that was hallowed ground to him now, for on it lay a four-year-old spike-horn caribou, which he had downed with one shot from his $40-44$ rifle.

The caribou, fat and glossy as a thoroughbred young Jersey bull, lay on the soft mossy ground. On one side stood the boy, with pride and joy and excitement beaming in his face. On the other side was the guide, amusing himself by poking fun at my incredulity. I looked a moment at the picture-for it was a picture, and one worthy the pencil of an artist-and at that moment I wasn't sure whether my pride in my boy was not as great as was the boy's in his caribou. 
After viewing the caribou over and over, turning him this way and that to see in which position he would look best, we carried him to the camp and hung him up by his haunches, in company with a bunch of partridges and ducks and a string of trout. Then we stood a little way off and pelted him with an amount of admiration that even a dead caribou ought to feel proud of.

But admiration like everything else must have an end, and after we had finished admiring him, we went to work to slsin and quarter him. We did the job, but it was with some reluctance and a little sorrow. Our consolation lay in the preservation of his feet and head, and these we saved in good shape for mounting.

Perhaps the reader may feel interested in knowing that this caribou head now helps to adorn a room together with other like trophies-beautiful deer heads with polished antlers, the heads of granddaddy caribou-bulls, and gigantic moose. All are precious, but the collection holds none that we prize more highly, or with which we would part more reluctantly, than the head of the little spike-horn bull of Eagle Lake. 


\section{$A$ Treacherous Coward}

O Monstrous Coward! What, to come behind folks? - HeNRy VI.

I wOJLD ask my readers if any of them has ever scraped an acquaintance with lumbago? He who has, probably knows, as I do, that of all the ills that flew from out Pandora's box it is the meanest and most treacherous. I say "treacherous" for I know of none in the whole catalogue that is so much in the habit of sneaking behind a man and, in an unwary moment, stabbing him in the back.

To him, however, who has thus far been lucky enough to escape a stab, I will give a bit of pointed advice; and it may prove useful should his luck ever desert him. The point of the advice has been sharpened by my own experience, and the burden of it istrousers. What has lumbago to do with trousers? Well, it is quite evident that he knows little about the ins and outs of lumbago, or he wouldn't ask the question. Now listen. If in the course of human events his luck should chance to go to sleep and thus give the lumbago an opportunity to creep up behind him and get a whack at his lumbar regions, he will soon discover where my advice comes in. Here it is, and it isn't lengthy-let him beware of getting out of his 
trousers if he has any desire or expectation of getting into them again. Every man who has ever put on a pair of unmentionables knows that the operation is accompanied by a certain amount of stooping. Of course, stooping is an easy matter to most people, but not to a man with lumbago. It would be easier, and perhaps more pleasant for him, to dive from the roof of a sky-scraper.

When I first tackled this complaint, or-to be precise-when it first tackled me, I was on one of my hunting trips. Now, it is quite bad enough when the shabby disease pitches upon a man in the midst of civilized surroundings; but when it attacks a hunter in the wilds of a forest, hundreds of miles away from civilization and his home, and throws him on his bed of spruce boughs, helplessly and almost hopelessly squirming with pain and beyond the reach of a doctor's aid, or the aid of anything else to soothe it, his predicament is rather piteous.

Now I am not the man to squeal before I am hurtnor even afterwards unless $I$ be convinced that squealing is the proper salve for the wound. No, my milk of courage hasn't enough water in it for that. Yet, although squealing may be an unpromising cure for one's harms, I admit that the man who doesn't do a little of it under the twist of a lumbago kink has more of that same milk in his composition than can be found in mine. And now for my experience. The reader will find 


\section{A TREACHEROUS COWARD}

the story of it full of truth and circumstance, and I will try to tell it without growing tedious, or straying from what the Immortal Bard calls "The plain highway of talk."

In the liunting season of 1893 I started on a trip accompanied by my son and four Indian guides. Our destination was the head-waters of the Peribonka-a river that flows into Lake St. John, two hundred and thirty miles north of Quebec. It was late in the Fall when we crossed the lake, and there was every promise that we would find ourselves in the clutches of Winter before we got back.

We entered the mouth of the river and paddled along for a couple of days, passing through gorge after gorge in the great Laurentian Stratum of rocks-a stratum which geologists tell us is older by millions of years than the sandstone or gneiss formation that characterizes the rocks of some of our own States. A virgin forest lines the shores. It is made up of spruce and fir-trees, tangled together like a tropical jungle. No road, no path, no clearing is to be seen-nothing but the great river for a highway. Up to that time the forest had escaped the lumberman's axe, save where it had been called in to cut down a little of the wood and thus clear a bit of ground for the camping parties. These camps are usually found near the various falls or deep pools that abound in this river and add to its weird beauty. 
The night of the second day was one which is now rather firmly fixed in my memory. The wind came from the north in true hurricane style and brought with it weather that might accommodate a variety of tastes. Snow, sleet, and rain whirled fiercely in our faces, while vivid flashes of lightning and their attendant peals of thunder gare a startling emphasis to the storm. Trees fell by the thousand, and the next morning our tent, which we had pitched in an open camping spot, was encircled by their trunks and broken branches. During the night the wild waterfowl were scurrying southward with express-train speed-speed which was somewhat aided by the wings of the hurricane. We heard the honk of the geese, though at times it was drowned by the cries of the small wading birds-the yellow legs, gray snipe and plover. The wild ducks, too, kept up an incessant whistle mingled with the whir of their swift-rushing wings.

The storm was the opening blast of Winter-a note of warning, as it were, from Old Boreas, telling us we must get out of that country or be frozen in. And it looked that way, for no sooner had the storm passed than we found the cold close at its heels, and it did not take it long to freeze the river tight along the shores. Our Indian guides looked glum, consoling us with the remark: "Heap cold comin'; big winter soon!" So we finally concluded to turn our backs to 


\section{A TREACHEROUS COWARD}

the north, and, like the rest of animated nature, join in a procession for more congenial quarters.

Our procession, however, did not get far before it was forced to come to a halt. The trouble was a portage about an eighth of a mile long and so covered with numerous windfalls as to be almost impassable; and trees were piled one upon another, the pile reaching five or six feet above the ground.

We found it was necessary to cut an avenue through the bristling branches, and this the Indians did. Then we hauled our canoes through, lugging our provisions and other stuff upon our backs. Perhaps I did more than my share of this work, for at the end of it I found myself overheated; and to this I attribute all the trouble that was soon to follow.

The storm abated during the day, the wind coming only in squalls with occasional dashes of rain, hail and snow. That night we pitched our tents on the northern bank of Lake St. John, and had our supper, the storm breaking loose again before we had finished. After supper I began to prepare for my bed of boughs. My preparations, however, did not get far before they were interrupted and in a manner novel to me then, although the norelty is worn a little threadbare now. I was in the act of stooping over to unlace my boots when a sharp pain in my back suggested that some enemy was behind me and armed with a pitchfork. I felt the jab of its prongs probing my backbone, and if 
I attempted to straighten myself into an erect position a fresh jab would double me up. "What the deuce can be the matter with my back?" This question naturally crossed my mind, and I never before queried it with a stronger desire for an answer. For fortyseven odd years had I boasted of my back and its ability to shoulder difficulties; why should it now begin to cut capers and "go back on me"? Had it come across some difficulty it couldn't shoulder? Was it lumbago? Well I had often heard of the disease but had no more idea that it would saddle itself upon my back than I now have of saddling my country with presidential aspirations.

After many attempts, I managed to creep to my bed of boughs. The pain was excruciating and getting worse so fast that at ten o'clock it was unendurable; then I called two of the guides and offered them a liberal sum to paddle across the lake to Robervalthirty-eight miles away-and get a doctor. One, only, of the four Indians, could speak English, and the little that he spoke was of the "pigeon" variety.

They put their heads together and after a great deal of powwowing went out, looked up at the sky and then at the lake; then they came back to me, the pigeon man saying "Heap bad storm. You give two pounds tobac extry and we go." If the demand had been a hundred pounds, I was in full humor to grant it. After telling the "pigeon" what he was to say to the 
doctor, two of the Indians started to paddle their way across Lake St. John, and on as dark and stormy a night as ever shrouded its bosom. As soon as they left I set the other two Indians to work heating spruce boughs on a little sheet-iron stove, and placing them, hot as possible, under my back. But the treatment had little or no effect. The contraction of my lumbar muscles continued to increase and in a little while I was entirely unable to move.

They say "Necessity is the mother of invention," and in the stress of mine I directed the Indians to tie a long towel to the centre-pole of the tent; then, when the lumbago $t$ winges would become unbearable in one position of my body, I would seize the end of the towel and pull myself around into another.

And so the night went by, the minutes dragging themselves slowly into hours. To pass the time and make its moments a little less painful, I had tried various devices with the hope of diverting my mind from the lumbago. At one time I set my brain to guessing at the number of flocks and the variety of water-fowls that were flying on their way southward. But they came so close together and passed so swiftly, that all my guessing didn't amount to much.

The end of this-to me-eventful night, came at last. The morning dawned fair and bright and saw me still lying upon my back and suffering with an agony that seemed to be piling itself up with each 
passing minute. How long was this sort of thing to last? I told one of the Indians to post himself on some high point of land where he might watch for the little steamer with its precious load of doctor and signal to me when it hove in sight. At twelve o'clock the signal came.

Then followed an hour of anxious solicitude. Though the weather was clear, the wind was very high, and the little steamer could be seen tossing in the waves like a cork. At times she would drop out of sight, causing the watcher to think she had gone to the bottom; then she would bob up again and struggle on her way against, what seemed to be, resistless odds. However, at one o'clock she reached her landing, and the eagerly-waited-for doctor stepped ashore. He was a kindly and cheerful French Canadian, and though his French was abundant enough his stock of English was slim. He told me that the little steamer had gone through a perilous voyage, indeed. Two of her three propeller blades had been broken off and she was forced to churn her way across with the remaining one. He also told me that the guides, whom I had sent for him, did not reach Roberval till eight o'clock that morning.

The doctor lost no time in getting to work on my lumbago. He gave me a hypodermic injection of morphine, following it up with another of the same 


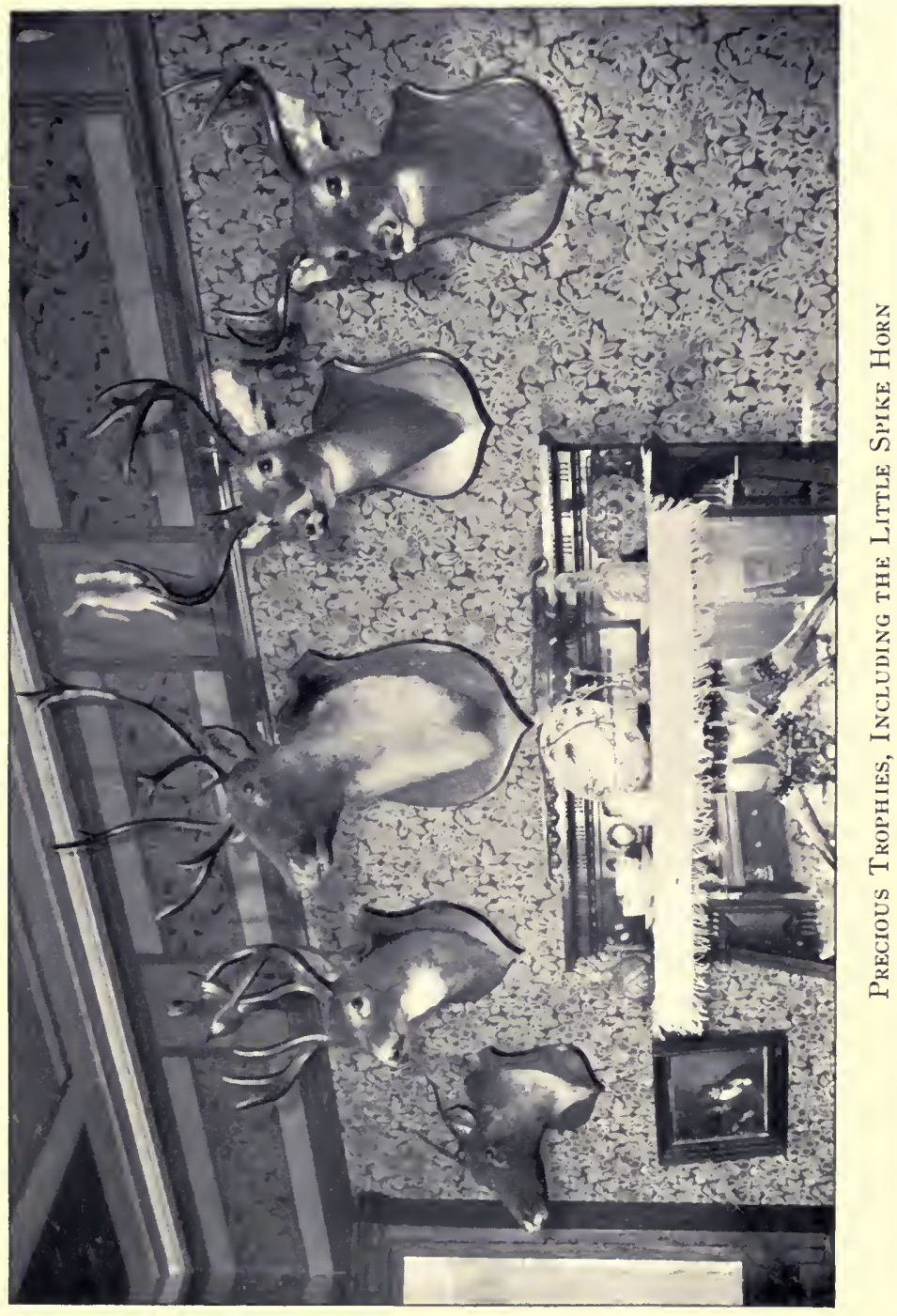





\section{A TREACHEROUS COWARD}

sort at night. Still I could not bear to be moved until the next morning. The steamer was now waiting to take us both to Roberval. She lay about a mile from us out in the channel and we were taken out to her in a rowboat.

At noon we reached our destination where a carriage was in waiting to take me to a boarding-house which was kept by a delightful old French couple who had formerly been employed in a nobleman's family in France. They doctored and nursed me with the tenderest care, and at the end of six days I was able to travel homeward.

But don't imagine, reader, that my back was now in prime order. No; there was still a stiffness and a "hump" there that took me weeks to get rid of. I did at last recover my normal health, but the beastly disease seemed determined not to forget me entirely. Recently it found me on another hunting trip, and in this way. It was raining very hard and I put on rubber hip boots and a new mackintosh and cape. The two latter are a delusion and a snare. They hold neither comfort nor much shelter and the hunter is wise that avoids them. I made a journey to a bog eight miles distant, taking the bed of a stream where the walking was easier than in the road. The water was cold, however-cold enough to keep my feet at an icy temperature-while the mackintosh kept my body in a perspiration. On my way up the stream I shot a 
deer, and the work of dressing it and hanging it up on a tree heated me still more.

When I arrived at the bog I ate my lunch and sat there for an hour or more looking for caribou. At two o'clock I left for the camp, reaching it at five. The mackintosh had been getting heavier with each mile, until it weighed, or seemed to weigh, full half-ahundred pounds. It is needless to say that, handicapped in this manner, the walk of sixteen miles had made me very tired. The next morning the lumbago made its appearance while I was stooping to lace $\mathrm{my}$ boots. Two distinct kinks in my back told the story of its arrival. And now comes in the trouser experience $I$ have referred to, and its relation may prove interesting, if not instructive, to the reader. I had been unwise enough to take them off the night before, and to get back into them again was a job I contemplated with alarm. Suddenly a brilliant thought struck me. I took two pieces of twine about three feet long, and tied a piece to each front suspender button. Then, backing myself up against a tree, I took one of the strings in each hand and dropped the trousers in front of me, taking particular care not to lose my hold on the strings. Then stepping a foot into each leg I drew the garment slowly and cautiously up into its proper place. It took me some time to accomplish the feat, but there was no especial hurry; besides, under the circumstances, I had a good deal 


\section{A TREACHEROUS COWARD}

more faith in deliberation. I have as yet applied for no patent on my device, therefore those of my readers who chance to get in to a like fix, are at liberty to use it.

Here is another hint that may be of service. Every man who has a touch of lumbago has with it an impulsive yearning to back up against, or sit down upon, anything that is hot-with the exception, perhaps, of a red-hot stove. While I was in Greenville, Me., and somewhat humped up with the disease, I came across a huge pile of sawdust that had lain all the morning under the rays of the warm September sun. Here was an opportunity my back was aching for. At once I squatted upon the top of the pile, and its warmth was so grateful that I sat there for a couple of hours, sandwiched, as it were, between the heat of the sun above and the heat of the sawdust below. Do I guarantee this an absolute cure? By no means. The ailment is too aggressive a fighter to be scared away by a pile of hot sawdust. I merely recommend it as a kink-soother.

Perhaps the reader may think it strange that after all my rough experience I still persist in roaming the forests in search of big game. Well, perhaps it is strange. One of my friends, who is something of a wag, declares that on these trips I am not after game at all, but in search of lumbago. "For everybody knows," he argues, "that lumbago is a disease of the lumbar regions, and therefore a forest is the most 
likely place to find it." Waggery on such a serious subject may seem to the reader like fiddling at a funeral. If his mind, howerer, should be at all perturbed with fears for the result of my future encounters with lumbago, I will set it at rest at once. That disease has no terrors for me now. I know so well how to master it that it becomes in my hands as docile as a well-trained horse. It no longer runs away with me. You ask me how I manage it? I will tell you. Should the disease catch me in the forest, I take the cure at once upon myself. I have abandoned my old method of sending forty or fifty miles for a doctor, for the reason that while I waited for the "curer of bodies" to make his appearance the lumbago was busy fixing its claws more firmly in my back. My new method is this: exercise, and plenty of it, and the more violent the exercise, the more effective it will be. I generally open the ball by trying how far or how high I can jump. There is not much fun in this, for at each jump your back feels as if it had been split open. After the jumping I take a canoe and paddle it for an hour or two. Then I pick out a road, and this, to be of service, should run to the top of some high ridge. The worse the road is, the better it is-for the purpose. It should be full of windfalls, soft wet places, and plenty of rocks-a road, in fact, where even a well man would soon grow weary of slipping and sliding and crawling over and under the 


\section{A TREACHEROUS COWARD}

logs. Now, if such exercise would tire a man in a wholesome condition, how does it act upon one who has to carry with him an unwholesome load of lumbago ? Well, I presume there are many who wouldn't care to try it a second time. However, it is a part of my method and therefore I must insist upon it. After my walk I return for my dinner, with my anatomy still doubled-up, but with the conviction that my first brush with the enemy has sapped his entrenchments, and that another one will knock his fortifications into smithereens. After dinner I take a second walk, choosing, this time, a wet bog and trudging through it, ankle-deep at every step, back and forth until the perspiration starts as freely as if I were in a Turkish bath. Then I return to camp, and at night apply a hot-water bag to my back. Next morning behold me spring from my couch of spruce boughs! Undoubled and erect, "Richard's himself again!" After breakfast I go for another dose of my walking-physic. True, it isn't as gentle and palatable as it might be, but the dose goes down much easier than it did yesterday. After the walk I return to camp and-well, the battle is over, the victory won, and my Machiavellian enemy has surrendered unconditionally. I retire to my spruce boughs and the next morning finds me without a pain or an ache and with a soul eager and hungry for the sport that only a moose or caribou can give me. 
And now, dear reader, I have finished my essay on lumbago. Should you chance to be bothered with this tormentor of humanity, don't dally with it but adopt my treatment at once. It is true that the paddling of canoes and climbing over rough roads and tramping through wet bogs are not among the recreations of ordinary city life; but the jumping part of the programme is open to you. If you do enough of this you will probably think you can dispense with the other enjoyments, and possibly you can. Resolution and pluck are the only ammunition you will need to fight your battle to a successful end. I admit that my tactics are rather heroic, and that there is one difficulty always standing in their way-the difficulty of getting together enough of the fore-mentioned ammunition. 


\section{The Great Northwest}

Well hast thou lesson'd us.

-Titus Andronicus.

Tine first thing that struck my attention on my northwestern trip was Canada's nagging policy in regard to American travel.

I had two guns and a case of shells on which duty was claimed. These, I explained, had been in use over six years and that I was going for only a few days shooting in Canada and then would return with them across the borders. But my explanation had no weight. The shells were counted and duty at the rate of thirty-five per cent. was exacted upon them, with conditions that if I took the guns back out of Canada within two months they would refund the duty, but not if they should be kept a day over that limit. Such is international courtesy between two countries with a border line of four thousand miles.

I passed through the famous Soo Canal where our Government was (at that time, 1892) enforcing a retaliation policy against Canada. It was therefore interesting to hear the conversations of the Canadians and Americans on the vessel and along the canal. We were detained there four hours in getting an entrance to the lock. The Canadians pointed out the fact that 
their own canal, which was then in course of construction, would soon be finished, and would give them the opportunity to retaliate by putting up the tolls to American ressels in the Welland and other Canadian waterways. They said it was a small, petty thing for a great country like the United States to do, and that Canada would more than get even in the long run.

The Americans, on the other hand, said it served the Canadians right, for they were al ways nagging and bullying us, behind England, on the fisheries, the Behring Sea and other questions; and it was time to teach them a lesson. The commerce passing through this canal in Canadian bottoms is very small, sometimes being only a little over four per cent. of the whole. Out of an almost continuous procession of steamers, tugs and sailing vessels which we passed in the "Soo" River only one was Canadian, and she was a small fishing smack. So, pecuniarily, the retaliation policy didn't amount to much; it was the sting and smart of it that counted. American craft went through free and Canadian craft paid twenty cents per ton toll.

It is said that more tonnage passes through the Soo Canal than through the famous Suez Canal. The Soo Canal is open only about seren months in the year and is totally inadequate for the immense traffic passing through it; therefore our Government built a new 
canal, with a lock eight-hundred feet long, eighty feet wide and twenty-one feet deep. The former lock was five hundred and fifteen feet long, with a sixty foot entrance, eighty feet inside, and about fourteen feet six inches deep. The Canadian Government has made theirs a thousand feet long and sixty feet wide throughout.

There is no object lesson equal to this American Canal in demonstrating the enormous resources of the great Northwest. As far as the eye could reach in both directions I saw an unending procession of vessels bound both up the lakes and down; those passing down being loaded to the deep water line with iron ore, grain, lumber, etc.; those passing up, with coal and general merchandise. And so it is every day while navigation is open.

What a lot of people with diversified pursuits our Canadian Pacific steamer was carrying! Sitting opposite to me at table was a typical Englishman, formerly a coffee planter in Ceylon but now a large land proprietor in Manitoba. Another Englishman had been out to the East Indies elephant shooting and was on his way to the Rocky Mountains to try his hand on the grizzly bear. He was a strenuous adro. cate of the Martini-Henry rifle for large game and wouldn't think of shooting a Winchester (probably because it is American). A number of passengers were going to shoot prairie-chickens, ducks, etc., others 
were on their way to buy land near Winnipeg. One wanted to sell land up there, and wanted badly to sell it. Merchants were returning from England, Montreal and Toronto, having bought their fall and winter stock; others were journeying across the continent en route to Japan and China.

Coming up the Soo (or Sault Ste. Marie) River, out of Georgian Bay, I was deeply impressed with the magnitude of the great Northwest's resources. An almost continuous string of grain and ore-laden schooners, steamers, barges and whale-backs kept passing us for miles, and on arriving at the mouth of the canal, which is but a mile long, we were detained four hours waiting our turn to get through its one lock. The vessel in front of us was the largest steamer on the Lakes-the Mariposa-over 4,000 tons burthen, and while the lock could comfortably accommodate four large schooners at one lockage this steamer so filled it that no other vessel could enter. She belonged to Ashtabula, O., and was going up with a light cargo of coal, and would reload with iron ore for her return trip. The Canadians seemed to think that our Government made a mistake in enforcing the retaliation policy on this canal, but after their astonishment and surprise at the action had worn a way they became indifferent. The Canadian Pacific Railway was the principal and about the only sufferer; and it wasn't much of a sufferer, either, as the total Canadian tonnage 


\section{THE GREAT NORTHWEST}

passing tlirough the canal, as I have said, is but a small fraction of the whole.

On reaching Fort William (an old Hudson Bay Company's fort) the first thing to attract my notice was a big wagon-load of fine French clarets, brandies and Canadian whiskies, marked "Hudson Bay Conlpany." I know not how strong the proof of the liquors may have been, but I do know that the load itself was to me proof strong as Holy Writ, that the people up this way have expensive tastes and the wherewithal to gratify them. From an unusually intelligent and well informed commercial traveler of London, Canada, I learned that the head offices of the Hudson Bay Company for this district are at Winnipeg, and that on his last trip to that town there were no fewer than thirty-two drummers at the principal hotel ; that these represented the dry-goods and readymade clothing interests alone, and that the buyers for these departments of the Hudson Bay Company looked at every man's samples before they bought a dollar's worth. Now, as this company also sells groceries, wines, crockery, hardware, drugs, stoves and tinware, guns, ammunition, etc., the reader will easily see what an enormous trade they still monopolize up here.

At Fort William the C. P. R. R. has three big grain elevators, and though the railroad ships the grain by lake and through the canal as fast as boats can be loaded, yet the elevators are often full to the roof. 
Their capacity is $1,250,000$ bushels. The train we met at Fort William was the transcontinental express. It had eleven cars, two of which were filled with Chinese passengers ticketed through from New York to China. Two cars of colonists were going out to settle at different points on the line. The cars were clean and comfortable-looking and were used at night as sleepers, having the same arrangement of berths as the Pullmans, without, of course, the luxurious appointments which characterize the latter. There is but one through train a day and this averages about twentytwo miles an hour.

The road is a single track, well ballasted, and has splendid rolling stock with good motive power. The management of the line contemplate bestowing the same attentions on the through first-class passengers as the trans-Atlantic steamship companies do, such as passing fresh fruit, beef tea, lemonade, etc., round to the passengers during the day-an innovation that other lines would do well to follow. The Michigan Central had already been in the habit of presenting bouquets of flowers to its patrons on reaching a certain station. Such little attentions do not cost much and they make a good advertisement.

The city of Winnipeg, with a population of 25,000 , was a veritable surprise to me. It has broad streets, half as wide again as any in our eastern cities, four lines of street car tracks, electric lights, electric rail- 


\section{THE GREAT NORTHWEST}

ways, opera house, fine stores and a hotel that would put to shame many metropolitan hostelries. It has a frontage on the main street of 216 feet, is seven stories high, with a rotunda forty by ninety feet and a dininghall fifty feet wide, ninety feet long and twenty-six feet high, grandly lighted by three copper electroliers, aided by a blaze of wall fixtures. Then there are massive stone fireplaces and also a balcony at one end, on which an orchestra enlivens the dinner hour.

The hotel has Turkish and ordinary baths, private supper and dining-rooms, and is heated by steam and lighted throughout by an elaborate electric plant. The charges are from three to seven dollars per day, and at these prices the house is well supported. This hotel, this city, and this Canadian Pacific Railroad with its progressive management are indexes of the enterprise of the Canadian Northwest. Here the "star of empire" may well hold its sway ; here future provinces and cities will rise from the level table-land of the prairies, by the limpid waters of the Assiniboine and Red Rivers, to grow rich, prosperous and happy in the lavish and generous returns from the tillage of a fruitful soil. Future colonies will leave their mother country, where the "dry husks of poverty" have been their support, and find here a glorious paradise of plenty. Here will grow up a strong-lunged, magnetic generation which must wield a beneficent influence upon the rest of Canada-and why not upon those 
sections of our own country that must surely come in contact with the almost boundless agricultural wealth and resources of the British province?

As we were about leaving Winnipeg, a banker of that lively town, in speaking of the great expanse of rich wheat lands around the city, said: "While the land in the neighborhood of Winnipeg raises fine wheat, and lots of it, one thousand miles further north they raise just as much wheat to the acre and just as good." One thousand miles further north! Think of it! I do not know and could not find out in what latitude Winnipeg is situated. I asked the clerk at the Manitoba House, among others. " "Well," he said, "I really don't know, but I do know it's an awful cold latitude." The railway guide says it is one thousand four hundred and twenty-four miles from Montreal, and yet good lands are being cultivated a thousand miles still further north. This fact helps to explain the enormous quantities of freight the Canadian Pacific Railroad is sending down, both by rail and water, to the lakes and through the St. Lawrence River.

At Regina, the capital of the province of Assiniboia, we were much interested in the House of Parliament, the Governor's mansion and the barracks and drill ground of the famous mounted police force. All are equipped with electric lights and other modern conreniences. 


\section{THE GREAT NORTHWEST}

The mounted police is said to be the best force of its kind in the world, and numbers over one thousand men. They patrol the whole North west, including the provinces of Assiniboia, Saskatchewan, Athabasca and Alberta, keeping in order the Indian population as well as the rest of the inhabitants who might be inclined to stray from the right path.

Canada's treatment of the Indian problem has long been acknowledged as wiser, more humane and more successful than ours and, as a result, we see the prairies dotted everywhere with Indian tents, the men being occupied with the business of farming or the grazing of cattle. They follow these pursuits contentedly and with good financial results. They are well dressed, seemingly prosperous and have generally overcome their instinctive desire for the excitement of the hunter's life.

What a sad sight is the great square piles of buffalo bones stacked up at different stations and awaiting shipment to the East where they usefully wind up their existence in the sugar refineries and manufactories of phosphates. The men who gather up the bones on the prairies and haul them to the station get six dollars per ton. As an indication of the extent of the business, the quantity sent forward from Moosejaw Station alone is counted by the hundred carloads.

When we think that the few pounds of bleached bones, forming one skeleton and bringing perhaps ten 
cents at the cars, were once the framework of the noblest animal that ever roamed over the continent, and that, had he been even slightly protected by law, by common sense or common humanity, he would have furnished us with the luxurious robe and succulent meat for years to come, the sight becomes indeed a sorrowful one. Soon these ghastly piles will be carried a way and nothing be left to mark the haunts and history of the buffalo, except tradition and the scarred sides of the slopes and valleys where he dug out his "wallow."

We saw coyotes very often after passing Moosejaw; also foxes and badgers; and as for gophers, their name is legion. Wild geese, ducks and snipe we also saw on many fresh water ponds and lakes. The 15 th of September opens the season for the prairie-chickenand thousands of guns crack away during that day and to the end of the season.

One afternoon we were out snipe shooting for a few hours, and on our tramp passed quite a number of Indian tents and villages; but neither the Indians nor their motley variety of dogs paid any attention to us, excepting one old buck with a red blanket thrown over his shoulders. This fellow followed us silently around, watching us intently, and, although saying nothing, seemed to be piling up a lot of thinking.

A party of ladies and gentlemen arrived here in their private car on a shooting trip to the coast. 


\section{THE GREAT NORTHWEST}

They ate and slept in the car and were quite successful in shooting and fishing. They left here on a side hunt for antelope and bears.

I wrote these notes seated on the broad prairie beside a palace car (wherein we were luxuriously fed and housed), waiting until the beds were made up and breakfast was prepared. It is something certainly novel, as well as very pleasant, to sit down in this latitude to a dinner of wild roast goose, teal duck, prairiechicken, fresh peaches, sweet potatoes, ice cream, etc., with plenty of drinkables besides, and all served by competent waiters. For this luxury we were indebted to a Worcester (Mass.) Excursion Company, who were on their twenty-second annual shooting tour and who had invited us to join them for the season. Seven gentlemen of the party started, with nineteen horses, tents, provisions, etc., for a hunt after antelopes and grizzly bears, their destination being some thirty miles from Maple Creek. They expected to be gone a week, and of course each man was anxious to bag his antelope or have a wrestle with a bear; in the meantime we had to be content to worry the prairie-chicken and mallard duck with our dogs and guns.

One through train from the Pacific and one from the $\Lambda$ tlantic stop here for a few minutes each day, and on their arrival the platform is crowded with Indians dressed up in their best bib and tucker, which means plenty of feathers, paint and tomahawk. With a 
special eye to business and the white man's pocketbook, they come provided with their peculiar wares, such as buffalo horns nicely mounted as hat-racks, trinkets of various liinds, pipes, etc. For some reason or other the Indian has a superstition against being photographed. Now, almost every train has its kodak fiend, and no sooner does he catch a glimpse of "Poor Lo" than out comes his box and the fun begins. We saw one of these enthusiastic fiends try to get a snap shot at an old "buck," but he didn't meet with much success. The moment the old fellow saw the photographer getting ready to point his box he rushed at him with an uplifted stick, jammed him against the car, took possession of his liodak and doubtless would have wiped up the floor with the picture-taker had the mounted police not interfered and ordered him back into the train. Yet the fiend wasn't satisfied. He went into the car and thrust the camera out of one of the windows. Instantly the alarm was given, and every squaw and brave, to the number of thirty or more, dived under the station platform, leaving the discomfited artist to the jeers and hooting of the crowd. One of the ladies of our hunting car, not knowing of this trait in the Indian's character, saw a bunch of squaws lounging around. She got out her kodak and commenced to fix it for a snap shot, when one of the squaws pantomimically threatened her with violence if she turned "that eye" on them. The lady 


\section{THE GREAT NORTHWEST}

didn't understand the pantomime and proceeded to take the picture. The squaw very angrily pulled a big stone out from under her blanket and threw it with all her force, hitting her on the wrist and inflicting a painful wound. There was no further use for the kodak on that car for awhile. The telegraph operator told me that the Indians are equally afraid of the " ticker," and it is hard work to get them near it.

On the night of the great prize-fight between Sullivan and Corbett the cowboys, ranchers, railway men, and in fact all the inhabitants of this frontier settlement, were in and around the station. The newspapers of Montana, the Dakotas and Nebraska having formed a syndicate to have the news wired to them in detail, it was sent over the Canadian Pacific wires. The operator sat in his office and in a conversational tone read the account of the fight as it passed over the wires, when it would be communicated to the outside crowd. Towards the last, when the "big fellow" was getting the worst of it, the excitement of the listeners was so great that they couldn't lieep still. Even the stolid Indian got enthused and grunted his satisfaction, and when the last sentence was ticked out then pandemonium was let loose. The only hotel in the town was besieged with thirsty customers, and all night long the yelpings of the coyote were blended with the yells of excited humanity.

The Bishop of Q'Appell, who is a baronet of Eng- 
land as well as Bishop, preached a sermon for us in the little chapel, and it was remarkable for its profundity as well as its eloquence. He is the leader in a morement among the Northwest churchmen which is intended to give new life to the Church of England by trying to arouse it from its apparent lethargy and by claiming for it the undivided support of the people, on the ground of its traditions, history and venerable age. In his discourse he easily disposed of the dissenting churches and then in a learned argument paid his respects to the Roman Catholic Church and proceeded to show that the Church of England was centuries older than the Roman Church. It seemed a great waste of force to preach such a sermon to the liandful of people he had for an audience, but as he leaves this country to spend his last days in England, after preaching here for twenty-six years, he no doubt thought it well to give the Canadians something to think about.

The Canadian Pacific Railway being the mostaccessible route between Alaska and the East, some very valuable train loads of merchandise pass over its rails. Probably one of the most precious loads ever hauled by a locomotive, in the same number of cars, was one made up of sealskins, filling ten cars, and booked through to London. Each car was valued at over $\$ 200,000$-over $\$ 2,000,000$ in all. The train had a wreck coming down the slopes of the Rocky Moun- 


\section{THE GREAT NORTHWEST}

tains. It parted in two, the back portion running into the front and smashing things up very generally. What a calamity it would have been - what a rude shock to the American feminine heart-had that train and its precious cargo been destroyed by fire! How many of the "lords of creation" would have been obliged to put their hand a little deeper into their Christmas pocket if the heart of their better-half should chance to be filled with love for a new sealskin! But, thanks to a providential decree that ordered otherwise, the calamity didn't happen. The train passed in safety, and its beloved cargo, having survived the boisterous gales of the Atlantic, came back to us, no doubt, in the shape of that most beautiful of all the adorning apparel of woman, the warm, glossy, cozy, fascinatingly lovely, but awfully expensive, sealskin sacque.

We reached Crane Lake on September 20th. During our ride in the hunting car "Yellowstone" we had matured our plans for a big day's sport, and we got it. I saw more sport in that one day-the 21stthan I ever saw before in a month. To briefly sketch the exciting incidents of the day would, perhaps, prove interesting, as all mankind, particularly the AngloSaxon part of it, has an instinctive interest, more or less keen, in everything that relates to hunting.

There were four of us. We got up long before break of day as silently as we could, so as not to dis- 
turb the ladies of the party (for, mind you, there were five of them journeying across the continent and back in the "Yellowstone"). We got away about five o'clock in the morning, just as the geese were commencing to fly from the lake to the neighboring wheatfields. We were posted along a low ridge, with strict orders to lie down quiet and snug in some thorn bushes. (If the reader has erer tried "lying down quiet and snug in a thorn bush" he will understand why it requires practice.) When a flock came near we were to jump up, single out a goose and give him some No. 1 shot.

The day was breaking in the east and shedding its faint gray light over the prairie. The dainty colors of the wild flowers, their pale yellows, their pinks and their purples were just becoming discernible in Nature's prairie panorama which she was now unrolling before us to rapture our sense with its beauty.

And now comes the cry of the wild goose: "Honk! Honk! Honk!" Looking up we saw a long line of them approaching high overhead. Crack! went the guns and away went the geese leaving none of their company behind. Down we dodged again and another flock came in sight. As before, another go of the guns and another go of the geese; and thus flock after flock flew over us in their particular wedge-shape order, but all too high. However, we rentured another crack at them. This time one was seen to drop 


\section{THE GREAT NORTHWEST}

down a little, recover himself, get back into the flock, drop again a few yards, and then, to our surprise, tumble heels over head, striking the earth a quarter of a mile away. A grain of buckshot did the work.

The morning flight was over and only one goose was bagged. We munched a few apples, then took setter dogs and started for the gamey prairie-chicken, which out here is really the pin-tailed grouse that goes before civilization, while the regular prairie-hen follows after it. The first bird flushed was taken by the youngest shot, my son James-boy of 15 years-and beautifully stopped. The second bird was similarly treated by the same gunner. The birds were popping up all around, and we all got our share.

We went back to the car, had breakfast, and were off again on a tramp to Crane Lake, about four miles away. Reaching the water, we found it literally covered in places with ducks, snipe, geese, yellow legs, pelicans, curlew and plover. A few shots started the whole aggregation in motion-mallards, plover and Wilson snipe began to tumble until we were loaded with all we could carry. A gunner away off across the prairie was heard to fire two barrels, then to shout, jump, run, and throw his hands up. No one seemed to know what was disturbing him, but in a moment we saw two dogs coming at a furious rate. No; one was a coyote, the other a dog in full chase. Four guns were discharged with No. 5 shot at the slinking 
coyote, but he got out of danger in a few minutes. Then a monster bird came flapping leisurely around the shore. It was a pelican, and, as if to chaff us into wasting our shells, he flapped serenely by in front of each gunner several times, each time getting the contents of shells from No. 5 down to buckshot. He was hit from every angle, some twenty-five shells in all having been fired at him. We could hear the shot strike and then drop into the water, and yet $\mathrm{Mr}$. Pelican "winked the other eye" and will continue to wink it at anything less than a rifle.

With our game belts loaded to their fullest capacity (mine must have weighed forty pounds, although it felt like forty tons), we started back, killing more prairie-chickens on the road, and arriving in time for dinner (five o'clock), having been out just twelve hours. What exhilaration was crowded into those twelve hours ! One who has nerer been out in this rarified and highly-electric atmosphere cannot conceive the joys of such a hunt on such a day. The sun was pleasantly warm, its rays being tempered with a cool wind that waved the tall grass and rippled the water so that it shone in the distance like burnished silver. Along the edge of the sloughs a row of willows bent their lithe limbs to the breeze and gave a graceful nod to each whiff as it passed on its way laden with the breath of prairie flowers. Surely, such Paradisal surroundings should satisfy any man's fancy, whether it 


\section{THE GREAT NORTHWEST}

belong to a hunter or to him whose ear can mark no difference 'twixt the honk of a wild goose and the crow of a barnyard rooster.

After dinner we had singing, whistling, by as good a whistler as ever "cocked a lip," and piano playing by two of the ladies who were good musicians. When our concert was over and we were about retiring, a knock was heard at the car door, and the members of the only family residing within miles of the station were announced as callers. So again the strains of one of Beethoven's immortal sonatas and a nocturne of Chopin's were involked to entertain the visitors, who were two ladies and a gentleman-the latter superintending a ranch of 10,000 acres. The latest fashions, the price of wheat, the climate, the habits of the wild fowl around the lake and various other topics were discussed. After a pleasant two hour's' entertainment the visitors were shown to the car door and left us saying it was the pleasantest night they had ever spent in their lives. So ended our day's hunt and pleasure at Crane Lake, Assiniboia Territory.

For months there was no rain in the regions gunned over by our party, and we pursued our sport without alloy or hindrance. When we were on the Frazer River, in Vancouver, seven of our party who had started away on a hunt after caribou and bears, returned to the car, after a trip of seven days, during which time they rode 130 miles over an almost impenetrable 
country, and among the mountains some 4,500 feet above tide level. For eight miles of that distance the road was so rough that horses could not be taken through, and the camp stuff had to be dragged and pitched over fallen timber, around rocks and under and over them. One of the party claimed this to be his twenty-second annual hunting trip, and he vowed he never saw anything to equal it for roughness and difficultics. They bristled with every step. One caribou and three deer were shot, and as they couldn't drag their game out of the country after killing it they gave up the hunt as a bad job and returned to the car, having taken three days to go up the mountains and two to return.

Two of the hunters were determined to get some big game, even if they had to go alone after it. 'They hired an Indian guide and a cook, got packhorses and provisions and again started out into the mountains where they proposed hunting big-horn-sheep up above the snow line. They made their way through from Canadian territory into the United States, arriving at Spokane, Washington, a distance of 245 iniles, camping up in the snow for several days, chimbing around snow peaks in moccasins, but always trying to keep face to the wind. They finally succeeded in killing four mountain sheep and three deer, but the hardships they had endured, as evidenced by their torn fiesh and clothing, will keep them from trying it again, for 
some time at least. As years glide by and civilization approaches nearer and nearer to the great mountain ranges, the big-horns and wild goats of the snowcovered peaks are pushed farther and farther back, so that it will not be long before these nimble-footed and beautiful creatures will follow the fate of the buffalo.

At Sicamous, a town of about one hundred people, on the main line of the C. P. R. R., in British Columbia, lives Colonel Forester who was in China when the great rebellion broke out in which General Gordon won his fame. Colonel Forester was requested by the foreign merchants in China to organize and drill what forces could be hastily gathered up, and to take charge of the defense; which he did, and so successfully that he was offered supreme command of the forces operating against the rebels. He declined, however, in favor of General Gordon. He has a large number of decorations, presents and letters testifying to his bravery and executive ability, and is quietly and modestly living out the remnant of his days in this lonely hamlet.

The scenery along the Frazer River is of the wildest, most interesting and most startling character. Fabulous amounts of money were spent in the construction of this part of the Canadian Pacific Railway. For a great distance it is a succession of tunnels, trestles, bridges and deep rock cuttings, the line clinging to the bald sides of the mountains and orerlooking the 
Frazer River that rushes along seething and foaming, and in some places a thousand feet below. On the opposite side is the old government road, which was made necessary years ago by reason of the gold excitement on this river, and also to facilitate the valuable salmon fishing. The road is now rapidly going to ruin. We passed thousands of frames of fishing tents left standing by their Indian owners. Wherever the river narrowed to a gorge, there they could be seen in the most inaccessible positions and fixed on the rocks like so many barnacles. How the Indians managed to get there or to stay when they did get there, it is hard to imagine.

The town of Vancouver has experienced a real estate fever of a very acute and inflammatory character. This was owing to its being the terminus of the Canadian Pacific and also of the magnificent line of steamers running to China and Japan. The town, with a population of about 15,000 , is situated on a fine bay, with a rich mineral, lumber and agricultural country tributary to it. The grit and enterprise displayed there is something that our eastern cities might copy with advantage. The Northern Pacific Railroad wanted to have an entrance there in order to reap a share in the rich Oriental trade pouring through the town from the great steamers plying to Japan. What did this little town of 15,000 people do to encourage the designs of the railway people? They put the 


\section{THE GREAT NORTHWEST}

question to popular vote, and the result was that they decided to give the railroad $\$ 300,000$ as a bonus to enter the town.

We arrived at Morley, Alberta, September 25th. The town consisted at that time of one store, three dwellings and the railroad station, having a total population of about twenty. It is of importance by reason of its being the distributing point for the reservation of the tribe of Stoney Indians. Large herds of cattle are pastured there by the Canadian Government to provide a weekly supply of meat during the year for the Indians, and the annual payment of five dollars per head is made and blankets distributed in accordance with the treaty stipulations.

The Indians are settled along the valley of the Bow River, some in tepees, but most of them in substantial and well-built $\log$ houses, each family having a small cultivated patch of ground on which they raise vegetables. Their ponies are hobbled near by and their cattle range the prairie. They spend a liappy, contented life, altogether different from the non-treaty Indians whose bad traits I observed so markedly in Maple Creek, and whose good qualities were not to be observed with the naked eye. I talked with a number of those who spoke English, and spoke it quite as well as the majority of white men. They had traveled some, could read and write, treated their wives and families with consideration, and, moreover, had accumu- 
lated a little wealth outside of the government allowance.

One Indian told me that he had not seen his father since he was a boy, until this summer when the father wrote him a letter asking him to visit him at a point a long distance still further north. He took a team of horses and drove there, the round trip occupying two weeks of traveling. He spent one week with his parents, and spoke of them affectionately.

The Stoney tribe speak the "Cree" language and belong to that race of brave fighters. A Mr. McDougal, who resides near Morley, has translated the Bible and the New Testament, as well as a book of hymns, into the Cree characters, which are said to be very simple and easily learned. He also preaches to the tribe and instructs them in their own tongue. He is a wealthy rancher, one of the oldest residents, and has seen the prairies when they teemed with roaming herds of buffalo, elk, antelope and deer. His house contains more stuffed specimens of animated nature than any other in this territory.

Some years since an enthusiastic young woman went to Morley as a missionary from Massachusetts. She was very successful in her work, and among her converts was a " noble Indian," whom she induced to go to college where he studied faithfully and well. On graduating he was ordained to the ministry, went back to Morley, made love to the young missionary, was 


\section{THE GREAT NORTHWEST}

accepted and married her. They are happy, and. though the wife's family is said to have ostracized her she seems to be satisfied.

Thirteen of our party, including four ladies, started on a prairie-chicken hunt to a point some $t$ welve miles away. As the Indians indulge in shooting chickens from the saddles of their ponies, thus depleting their numbers, it was necessary to take teams and drive this distance before we found the birds which even then were in only limited numbers and as wild as hares. When we arrived on the shooting ground it was nearly noon, and as the birds had finished their morning feeding and were found on the edge of the brush fringing a little stream, we had hard work getting more than a glimpse of them before they would be out of sight. Taking long flights made it slow shooting. However we made a fairly good bag, and, as it is always the practice of sportsmen and sportswomen to shoot only what they can use to advantage, we gave up the sport and the hard work in good season and enjoyed a glorious ride back, watching the forms and ever-changing shadows of the Rocky Mountains, which, though eighteen miles distant, secmed close enough to be reached in a half-hour's walk.

We were told that, at Bow River, all we had to do was to throw in our fish-lines, and, with any sort of a fly, we could catch all the speckled trout we could handle, and that Morley was the point on the Bow 
which gave the best results; but-how often these "buts" come in to upset trout-fishing calculation, and this particular "but" did it effectually - a road master on the Canadian Pacific had been drowned in the treacherous current, and the authorities, hoping to bring his body to the surface, exploded dynamite in all the pools up and down the river for five miles. These explosions, though they did not raise the body, certainly did raise the $d-1$ with the fish, killing nearly all of them. And thus, once more, our fancy and fond hopes of hauling in the speckled beauties on our sevenounce rods were scattered to the winds. After a whole day's throwing and coaxing with all sorts of flies, minnows and bait, we succeeded in landing only a paltry dozen or so.

Ten persons having lost their lives in the river near here within a few months, the ranchers, cowboys, and even the Indians, hold it very much in awe. The water is icy cold, from the melting snow and ice that rushes down from the Rocky Mountains; the current is swift and full of eddies, rapids and whiripools; and the stone on the bottom slippery as an eel. Woe betide the man who should lose his footing in fording and get overhead in it. His chances of getting out would be slim indeed.

We arrived in Banff early in the morning and slipped out before breakfast to see the town and spy out the points of attraction which the Canadian $\mathrm{Pa}$ - 


\section{THE GREAT NORTHWEST}

cific has set such store by. The town is nil-neinnix. A few log huts, a small brick church, a dozen or more frame-shanty stores, and stumps and fallen trees galore.

But the attractions are there, and they are attractions, too, with no nonsense about them. "Whatever the company has advertised to perform, that it will perform, or your money refunded," would apply very well. The luxurious C. P. R. R. Hotel, about two miles from the station, newly built, superbly furnished and lighted, spacious, comfortable and well kept, is a "number-one" drawing card. A sanitarium, a few pretty, small hotels, glorious drives among glorious mountains capped with everlasting snow, a park, twenty-six miles long by ten miles wide, embracing parts of the Bow, Spray and Cascade Rivers; the Hot Sulphur Springs, the Warm Sulphur Springs, bridle paths and walks up the various peaks, and the unrivaled landscape all aglow with the brilliant tints of its autumn foliage, make a combination of attractions that has already proved strong enough to draw tourists from all parts of this Continent and a great many from Europe as well-a fact that the register at the big hotel fully attests.

My choice in this list of attractions was to take a warm sulphur bath and then scale a mountain. Now, isn't it unique to take a bath in an enclosure open at the top, where the white caps of the mountains are 
seen all around you and the rain pouring in? And yet we swam in a pool of sulphur water at the natural temperature of ninety degrees, and with plenty of room for diving, fancy swimming and frolics generally.

The mountain climb was equally worthy of remembrance. I wasn't at all ambitious of tackling any of those giants that stand six thousand feet tall in their stocking feet. Oh, no; I selected a modest twelve hundred-foot fellow called Tunnel Mountain, and in face of fierce winds and gusts of rain (which on the higher peaks fell in the form of snow) I scaled it in about an hour and a-half. The view from the top was enchanting. Neither poet nor painter could describe or picture it; and therefore I, who have not the gift of either, will not attempt it. Suffice it to say, the scene is still in my memory and Time can't rub it out.

Coming down, like numerous other would-be smart ones, I thought it an easy matter to leave the carefully graded path, and by traveling straight down sare time and distance. Very soon my feet slipped from under me; down on my back I slid, grasping at shrubs, stones and plants in my rapid descent which kept up until its unpleasant speed was stopped by running into a tree. With scratched hands, torn pants, a bruised back and a little more wisdom, I concluded to keep to the path for the remainder of the distance.

Did it ever strike you how many difficulties there 
are to be encountered, distances to be covered and obstacles to be surmounted in the search after speckled trout? It struck us, but not until after we had tried it. We had so many broken promises of good trout fishing on this trip and so many disappointments, that when we reached Banff and found that-although there was any quantity of the fish there-it was close season in the park and we couldn't fish, we were about giving up all idea of ever seeing a trout. Just then we stumbled over a fellow who told us of a wonderful little lake, recently discovered and only fished in for the first time two months ago. He said the lake was located at Castle Mountain, seventeen miles from Banff.

Taking his word that it was full of trout, and notwithstanding his warning that he doubted whether our power of roughing it would hold out till we got there, we determined to go and find out whether he was a fish romancer or not. Our car was pulled there in the early morning. A guide had come with us from Banff, who filled us with glowing predictions of the luck we were going to have, but kept very dark about the difficulties and dangers of the trip. Seven of us started with him, unconscious of what was before us. He had led us along a small creek to a frail crossing made by a fallen tree. This was so slippery that one of our party lost his footing, tumbled, and had to go back for dry clothes. 
We then came to the Bow River, which here is a raging torrent, deep and treacherous. Stretched across diagonally was a very long boom, made by strapping together a string of two logs which were held to the shore by stout, wire cables. It is the only crossing within seventeen miles of Banff, and one not calculated to inspire confidence in the crosser. The boom was swaying up and down in the fierce rush of waters, the torrent surging over the logs, the inner one of which was half-covered with slimy, rotten bark that peeled and slipped off under foot.

The guide's shoes were armed with sharp-pointed spikes, which enabled him to skip across the logs with the ease and grace of a dancing master; we had on rubber boots, slippery as glass. There were two logs reaching to the boom, and the guide seeing we were not in his skipping condition advised us to creep over them on our hands and knees.

Four of us started across with our feet placed crosswise of the logs. When we were about a third of the way over the guide halloed at the top of his voice: "Look out you don't slip over; if you do, hang on to the logs like grim death or you're a goner! No man can swim in this water; he'd be sucked under and into Davy Jones' locker 'fore he could say Jack Robinson!"

This cheerful bit of information had the effect of making us doubly cautious. By dint of balancing and 


\section{THE GREAT NORTHWEST}

poising and feeling with our feet for the least slimy places we at last got safely over. We then had time to realize what idiotic fools we had been to risk our lives on such a crossing, and, for what? - a few trout.

We motioned to the three men we left on the other side not to attempt the passage. They signalled "all right," and we started ahead. Afterwards one of the three made up his mind to try it. He labored along very cautiously until near the middle, then his foot slipped and in a twinkling he was struggling with the stream. Fortunately for him, he fell on the inside. He was a strong, athletic young man, and managed to throw an arm around the inside log before his body could be sucked under; then by an almost superhuman effort he pulled himself on to the boom again. Having got back safely he went to the car for a change of clothes. To-day he is full of thanks to Providence for his narrow escape; and well he may be, for his chance of life in that caldron of ice water was-well, one in a hundred.

Shortly after leaving the river we struck a good trail up a mountainside. It ended in an almost impenetrable jungle of fire-swept timber, orer, under and around which we panted, perspired and labored for an hour. Then suddenly, as if by magic, there flashed upon our sight a lovely little gem-of-a-lake circled around by great mountains, whose sides were sheeted with snow nearly to the water's edge. We at 
once jointed our rods and baited our hooks with live grasshoppers, of which we had plenty. Hardly had I struck my line into the water when a speckled beauty took the hook; and then another and another, and for a couple of hours it was nothing but a swish of the line and a tussle with the trout.

Soon we had as many as we could carry. Meanwhile, the men we left behind had, with the assistance of the guide who had returned to help them, resurrected an old scow and crossed. About two o'clock they appeared with a welcome lunch. The car log-book of game credited the party with a catch of some three hundred and fifty trout, and that was certainly enough to last us some days, as we had them carefully packed away in the refrigerator.

Next morning our car was coupled to the Pacific express and hauled to that wonderful spot, the great Selkirk Glacier. An excursion was promptly made to the glacier, which is said to be seven miles long, two miles broad and of solid ice 2,000 feet thick. A fine object lesson is here obtained of the resistless power of the ice in crushing, powdering and moving enormous masses of rocks. Avalanches, landslides and terrific storms are of such frequent occurrence during the winter and spring that the occupants of the railroad hotel and station are in daily terror of their lives.

Early one morning a couple of our sportsmen, armed 


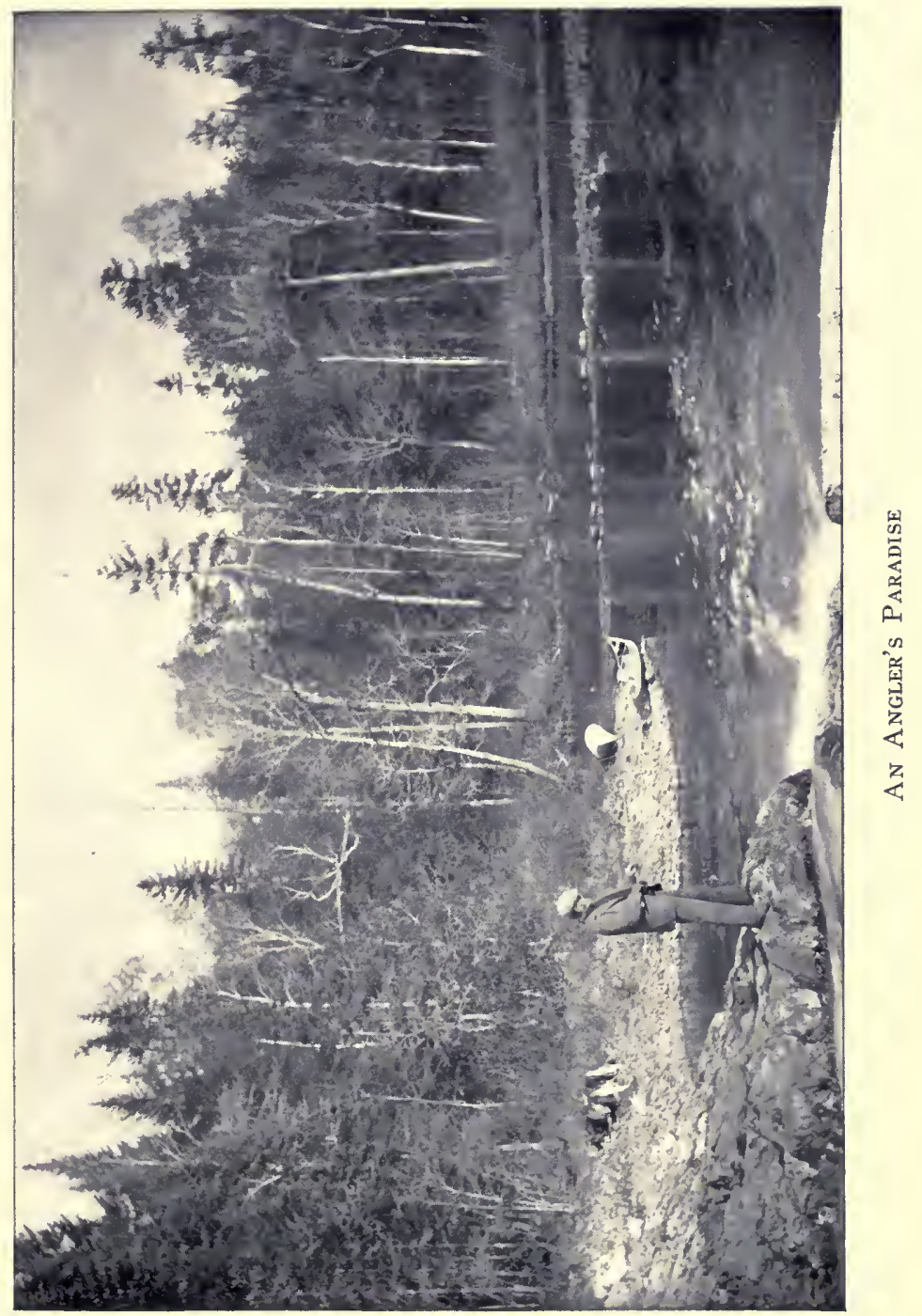



with rifles, started away from the car hoping to get a sight of a bear. Six of these animals-two grizzlies and one black bear, each with a cub-were reported to be feeding on berries less than a quarter of a mile away from the station. In a very few minutes three shots were heard, then five in rapid succession, then another shot, and we divined that a bear had surely fallen. Excitement ran ligh and all were on tiptoe of expectation, until the two hunters returned-without the bear.

It took some time for the truth to gleam through the glamour surrounding that early morning encounter with bruin, and here it is. A railway employee had located the bears and at daylight crept down among the berry bushes where they were expected to feed, and patiently waited with the determination of bring-

- ing one down. The track here makes a sharply defined horseshoe curve, and on one arm of this curve is a snow-shed a mile long. One of our liunters liad climbed on top of this shed and walked along for half its length when he saw a bear come out in an open patch seven hundred yards away. Now, he couldn't get off the shed without going to the end of it and by doing this he feared he might lose sight of the bear. So to lose no time he commenced firing.

The other hunter saw with his glass a man down in the berry patch and thought hunter number one was shooting at him. The man in the berry patch seemed 
to think so too, and after his ears had listened to the close whistle of seven or eight bullets, he emerged from the bushes and walking up to hunter number one opened on him a battery of Western words that fairly - smoked with brimstone. I'll omit them here, only saying that they conveyed the idea that the bullets had nearly hit him. "Besides," he said, "how the devil do you expect to shoot bears from the top of a snow-shed three-quarters of a mile away?"

It took lots of oily words to smooth out the berry man's waves of indignation. After warning hunter number one that if he valued the integrity of his own hide he had better not try that sort of fun again, but keep his bullets in their pouch, where they evidently belonged, he finally agreed to an armistice and a drink of whiskey.

Number two had in the meantime followed the bear away down the river but lost the trail and dejectedly returned, adding his opinion to that of the berry-bush man: "The idea of a fellow trying to shoot a bear from the top of a snow-shed and across a whole county!"

And now we reached Lake Okanagan, where we resolved to try our guns on the wild geese and ducks.

By the way, like the immortal Mrs. O'Brien, who, when she had acquired wealth and position in society, insisted upon calling herself Mrs. O'Brion, with the accent on the last syllable, Lake Okanagan is not 


\section{THE GREAT NORTHWEST}

Okanagan at all, but is pronounced Okanawgan, accent on the third syllable. It is named after a tribe of Indians (a branch of the Chinook race). It is about eighty miles long and from two to twelve miles in breadth, and is well filled with silver trout, salmon trout, chub and lake trout. The growing town of Vernon, with a present population of about four hundred, is five miles from it. The lake is bordered by a remarkably fine piece of ranching and agricultural country, and on account of the depth and coldness of its waters, the beauty of the scenery, the wealth of wild fowl and the wonderful climate, it is destined to become a prominent summer resort for residents of the Pacific coast near Vancouver and Victoria.

The lake and the town of Vernon are reached by a branch of the Canadian Pacific Railroad fifty-one miles long. This branch, though in operation but a comparatively short time, is already paying handsomely. Previous to the building of the C. P. R. R. main line, all merchandise had to be transported on packhorses a distance of two hundred and fifty miles from Fort Hope, on the Frazer River. The item of freight was then a very serious one, as it amounted to eleven cents per pound on sugar, nails, hardware, coffee and all heavy articles, and a proportionately higher rate on more bulky merchandise. It must be from this reason then, that, although the railroad has not been opened long and the freight charges are very 
moderate, the merchants have not got used to the changed condition of affairs.

Everything is absurdly high. You are charged twenty-five cents for a shave, fifty cents for a pint bottle of apollinaris or Bass' ale, and corresponding prices for everything else. But the livery stable men are the real Shylocks of the town. A physician was dilating upon the qualities of a very good young mare he had just bought for ten dollars, and assured me he could buy any number of them at that price. I thought, as horse flesh was so cheap, I should be able to enjoy many drives and see the country without injuring my pocket. The thought was hardly a sound one. At my first trial of it, the stable man charged me five dollars for a very sorry looking horse and a dilapidated buggy whose years might have equaled those of the "Deacon's one horse shay." The charge for a pair of similar looking animals and a similar looking wagon I found to be ten dollars. Such modesty is rare.

We had been here a week, and, while there were three livery stables, all doing a rushing trade, we had never been able to see the proprietor of any of them to know whether the charges exacted from us were warranted or not. In fact each proprietor seemed to be more interested in slooting or horse-racing than in looking after his business.

This is truly a wonderful belt of country, and the most fertile we have yet seen. The Presbyterian min. 


\section{THE GREAT NORTHWEST}

ister here told us that the soil in places is fully fifteen feet deep and of the richest black loam. The wheat averages over thirty bushels to the acre and weighs sixty-five to sixty-six pounds to the bushel. They make no rotation in planting. It is wheat and wheat year after year. We saw a field just harvested that produced thirty-two bushels to the acre which luad been sown with wheat for twenty-three consecutive years, and another field of forty acres that last year had not been sown, but simply ploughed under, with the previous year's stubble on it, that netted its owner (a half-breed Indian) $\$ 700$. Fruits, hops and regetables are equally prolific.

The climate is dry, with hot days, cold nights and few sudden changes. September days are as hot as those of July and the nights cold enough for November. The only doctor in the neighborhood told me he never saw nor did he ever read of such a healthy district. Children don't get sick. People eat well, sleep well and live long, and the only business on which a doctor can earn his living comes from accidents or from practice incidental to the natural increase in the population.

One of England's Earls, at one time Governor-General of Canada, has a ranch four miles away, which is managed by his brother-in-law, the Hon. Major Majoribanks. He also has another ranch of several thousand acres at Mission, a settlement at the other 
end of Lake Okanagan. His lordship owns almost countless herds of cattle and sheep and droves of horses and pigs. We saw a couple of young sportsmen here who boasted of being relatives of the Duke of Argyle; so taking it altogether, the little town was full of fuss and noble feathers. The Earl's lower ranch, Mission, has been irrigated and rented out in plots of twenty acres or more to fruit farmers, for whose use it is peculiarly adapted.

Four of us had good sport during the week, shooting prairie-chickens, ruffed grouse and wild geese. A little lake four miles away was almost covered during daytime with the geese and ducks. The geese leave the lake every morning and evening to feed on the stubble left standing in the wheat-fields, and on their passage to and fro comes the only chance to shoot them. On arriving here we left our car, selected favorable locations for sinking pits to shoot from, and then went to work with spades and a railroad crowbar. After the plowed surface was removed the earth was found to be almost solid black loam, and as this reached down as far as we went, nearly five feet, the digging was hard enough to start the perspiration and blister our hands. When the pits were dug a couple of dozen sheet-iron, decoy geese were set out; then we covered the edges of the pits with wheat straw, hiding every lump of fresh-turned earth, so that nothing could be seen which would excite the suspicion of 


\section{THE GREAT NORTHWEST}

the geese. We had scarcely finished our task when we heard their first "honk! honk!" Down into the pits we tumbled like gophers, and crouching together with scarcely breathing room we saw flock after flock sail over without giving much attention to our painted sham-geese. Then another flock came which had more curiosity. To and fro they sailed by us, circling around to find out if things were "on the square," each circle bringing them lower and lower until we were satisfied they were within gunshot. Then up we jumped and blazed away. And the geese Hew off apparently untouched, but only apparently; we saw one of them lag behind, then drop a little, then rise to the flock, and in a second or two tumble headlong a quarter of a mile away. Another faltered and fell a half a mile away. We found the first with the aid of a dog, hidden in a bunch of grass; the other, for which we searched in vain, was found by a cowboy two days after.

Thus early in the morning and evening we were in the pits enjoying this most exciting sport, and bagged enough geese to supply us with all we could use, and an occasional one to give away. At this season of the year they are fat and delicious eating.

Six gentlemen of our party started on a "big game hunt" into the district of the Gold range of mountains which abounds in caribou, grizzly and black bear, Rocky Mountain goats and mountain sheep. They 
took with them three Indian guides, a white cook, and a squaw to cool for the guides. As their camp outfit had to be carried on pack horses sixty-five miles, when they started off they made a very respectable cavalcade. The roads, as well as the hunting ground, are of the roughest description, and, moreover, as each man was compelled to take out a $\$ 50$ license to shoot deer, he surely earned all the game he brought back. As far as we can learn this license or tax is only levied on Americans (Yankees we are called here) while Englishmen, Frenchmen or men of any other nationality are never required to take out a license. If this is really so, it is only another proof of Canada's vexatious policy toward her big and wealthy neighbor. It also proves how short-sighted they are, as such a policy will never bring reciprocity, which all Canadians sigh for, but retaliation, which they can ill afford, and which is as unseemly among nations as it is among men.

While in the ticket office at Vancouver, British Columbia, we were much amused at a party of three Englishmen belonging to the nobility of England, who were trying to engage a compartment on one of the C. P. R. R's first-class cars. They couldn't, "you know," travel in a car with ordinary people; but the ticket man assured them there was nothing else for them to do, as there were no compartments, and the company could not arrange one before the train 
started, no matter how important it might be to them.

They agreed to pay an extra fare if the smoking end of the car could be reserved for them, and they authorized the conductor to tell the passengers that they were cholera suspects or smallpox patients, or any thing he liked, in order to keep the "common people" away from them. But all to no purpose. There was but one alternative-take their "medicine" or stay behind.

It was somewhat amusing to hear their criticisms on Uncle Sam's "frightfully vulga' country and beastly traveling, don't you know."

The route from Vancouver, in British Columbia, to Seattle, Wash., lies through a rough, heavily timbered district, where the trees measure any where from three feet to six feet in diameter. These are of the red cedar species and are being rapidly sawed down and cut into lumber and shingles.

Why it is I cannot tell, but it certainly is nevertheless-I mean that the railway is literally lined with a row of bursted boom-towns, each with a bladder-like name, a big hotel, a public hall, maybe, and plenty of saloons flaring suggestive signs, such as the "Blazing Stump Saloon," "New Idea Saloon," "Three of a Kind Saloon," "Let her go Gallagher Saloon," etc., etc.

Evidence of " bustedness" looms up everywhere. 
Streets deserted, dwellings vacated and closed, and no sign of life, except it be the shingle mills and the woodchoppers' shanties on the outskirts and away from the "avenues" and "boulerards" that grace these silent towns.

A real estate dealer in Seattle told me that the growth of his town had been much retarded by investments in these mushroom spurts-investments which promised no more returns to the investor than if he used his capital in buying up town lots on the moon, or in leasing the rainbow for a paint-shop.

Seattle and Tacoma are less than forty miles apart, and as both towns are ambitious and growing there is great business rivalry, as well as bitter jealousy between them. Each claims the larger population, business and wealth; each declares it has the brighter prospects for the future, and each delights in decrying the boasted advantages of the other. Our candid and unprejudiced opinion is that Seattle is, by all odds, the more enterprising, and therefore the more promising of the two. Certainly it has much more life than Tacoma, and more public spirit.

Tacoma had been so nursed and coddled by the Northern Pacific that, in a measure, she lost her independence. On the other hand Seattle had to scratch and fight for her railroad favors, and fought so well that she compelled the Northern Pacific to come off its Tacoma perch and hustle for its share of the trade. 
After the Great Northern Railway opened in Seattle, the difference was still more marked.

During our trip we enjoyed the luxury of trolling for salmon in Puget Sound, both at Seattle and Tacoma, and with fairly good success. Each of our party, save one (and he was the professional "lone fisherman" of the party) caught one or more salmon. While the sport was very exciting, I confess I was disappointed at the tame fight they make when hooked. There is a good deal more fight and fun in a four-pound bass than you can get out of a sixteenpound salmon. But they are beauties; and when you have one of them safely landed and lying in the bottom of the boat, his lack of gameness is overlooked in your admiration of his beauty. Our fifteen-yearold sportsman was not to be outdone by the older hands, for he not only hooked and landed his salmon, but he also landed a trout with the trolling line and spoon, a feat which none of us had ever before heard of.

It is needless to say that the catching and canning of the salmon is a very large and profitable industry. The number of people dependent upon his iridescent highness for a living, and the number too, in all civilized portions of the globe, who find economical and delicious nourishment in his red and juicy steaks, would be beyond the ken of man to tell. Yet it is safe to say that no one product of our Western 
Hemisphere serves to advertise and popularize the country more than the canned salmon. Millions of tins are annually shipped east or exported to Europe and sold at such prices that canned salmon is now rightly considered the handiest, the cheapest, and the most nutritious cooked-food of the century. 


\section{North Dakota}

A sportsman's paradise, in truth, is this Where nothing mars or meddles with his bliss; Nimrod himself might envy such a spot, Nor find his game unworthy of his shot.

-Whitron.

Doubtress, North Dakota is the "paradise of the sportsman," but I am not so sure it contains nothing to "meddle with his bliss." Indeed I have strong evidence to the contrary which I will spread before the reader a little further on.

One of our trips found us in this paradise where we wound up our bliss in a blaze of magnificent sport at Dawson. The proximity of this place to enormous wheat-fields and innumerable sloughs, ponds and lakes, causes all kinds of aquatic game birds to congregate here and in the greatest abundance. All the duck tribe-including the red head, the mallard, the widgeon, teal, black and bald pate-the Canadian gray goose, the beautiful white goose, sandhill cranes, the plump, solid-meated prairie-chicken and many others of the feathered game-tribe are here awaiting the pleasure of the sportsmen. The "sports" are fully aware of the delights that await them and they come from all parts of the country, but particularly from St. Paul and Chicago, with their 10-bores and 273 
12-bores, their retrieving spaniels and their Irish setters.

The town hasn't over two hundred inhabitants, yet it boasts of a large hotel, which, in the hunting season, reaps a bountiful harvest from the pockets of the lots of men who know how to shoot-as well as from the pockets of lots of them that don't.

The migratory wild fowl make their way down from the far north in countless multitudes, feeding on the wheat-fields and ponds in the early morning and late evening, and resting in the centre of some lake large enough to keep them from out the reach of the deadly breech-loader during the day.

The flights of geese are something wonderful, and it is even more wonderful that so few of them are shot. But there is no bird more wary or suspicious than the Canada goose. They will settle nowhere without first carefully looking the ground orer. From the height at which they fly, and in the rarified atmosphere of the prairies, they can see for miles, and carefully avoid any moving object, especially if it be that of the human form.

We had spent sereral days there before we were able to discover the fields on which they were feeding. When we did find the place it was literally covered with their droppings and their breast feathers. We selected a suitable spot, dug two luxurious pits, fixed the edges up with wheat stubble as carefully as possi- 


\section{NORTH DAKOTA}

ble, set our decoys and jumped in to await the coming of the "honkers." We had been waiting only a few minutes when we saw, away off on the prairie, what appeared to be a man with a dog. The man seemed demented, jumping and running around and lying down on his back, then jumping up again and repeating these operations in the most eccentric manner. We held a whispered consultation from pit to pit as to what was best to be done. It was folly to think that the geese would come from the clouds for the purpose of getting a closer view of his capers. Oh no; we knew they were not such geese as that; so it was decided that I should be the Ambassador Plenipo with full power to coax, drive, persuade or kick the funny intruder off the prairie. When I reached him I found, not a man, but a stubby, barefooted German boy, whose feet were sore from walking over the sharp-pointed wheat stubble. Hence his tears, I thought, for he was crying. But I was mistaken. His grief was not of the sore-footed sort. He was only a prairie specimen of "little Bo-Peep," who had lost his sheep and didn't know where to find 'em.

With more ingenuity than veracity, and a very ragged attempt to handle his mother-tongue, I told him when and where I had seen them and then advised him to hurry away in the direction which I pointed out and he would soon catch up with their tails. 
Watching him until well out of sight and pluming myself on my diplomacy I returned to the pit. I had been there but a short time when the screaming and honking of the first flight was heard. Then raising up and peeping over the edges of the pit I saw a great moving cloud coming straight toward us. But, horrible to relate, there was something else coming, and something that promised to "meddle with our bliss" most effectually. An old, black horse with a girl on his back wabbled toward us and when near enough for us to hear her the girl stopped and yelled at the top of her voice: "Where did ye see my she-e-e-p?" "Oh, for heaven's sake," I said, "get out of this! Move on! Don't you see you're knocking our sport into smithereens?" But she didn't or couldn't or wouldn't see anything of the sort, until one of our men threatened to put a charge of shot into the old horse unless she hurried him out of the way. The threat improved her eyesight, for at once she commenced whipping up old "Rosinante" and in a little while both had disappeared in the distance.

And so had the geese. The flock on seeing her had swerved by us a quarter of a mile away, and nothing now could be done but wait for the next flight, which in fifteen minutes we heard coming toward us, fully a couple of miles off. We had just time to ask ourselves whether there was going to be any further meddling with our bliss when a meddler showed up 
to answer for itself. This time it was in the shape of a woman, evidently Bo-peep's mother, accompanied by the rider of the black horse. The girl had ridden home, told her mother we had threatened to shoot her, and now the old lady was here with the martial fires of her fatherland burning fiercely within her and sending her blood up to the boiling point. When she got within shouting distance she opened her batteries. She would listen to neither explanation nor defense and actually charged us with having frightened her sheep away by having a retriever with us; and then she vowed vengeance. We entreated, implored her to leave us, to go away anywhere, so the geese wouldn't see her; that after they had passed she might come back again and we would try to accommodate her with all the vengeance she wanted. But no, there she stood, working her jaws and hurling her brimstone at us, and waving her arms that flew around her head like the sails of a windmill.

The geese passed over and away out of range and sight. Then her arms resumed their equilibrium, and with a few more hot words and a farewell shake of her fist she turned and slowly disappeared orer a knoll. And we? Well, we got out of our pits and with spade and shovel silently filled them up again; then, hardly daring to trust ourselves to speak, we got into the wagon and drove to the train, for this was our last hunt for the season. 


\section{The Wrecker}

A brave fellow ! He keeps his tides well.

-Timox of Athens.

Or a barren and desolate dune of four miles long and a quarter of a mile broad-laid down on the old charts as "Malabar" Island, but now, for some reason, I know not what, called Monomoy Island-a number of professional wreckers have pitched their lives to ply their risky and speculative calling.

Wreckers and pirates were once linked together in my mind, for I thought the terms synonymous. This, however, as the reader may surmise, was in

"My salad days

When I was green in judgment."

I soon discovered a wide difference. The wrecker is a man who will, and does, risk his very life to save property, whether it be vessel or cargo, as well as to rescue the lives of those in peril. In the pursuit of his calling he shows heroic bravery, great nerve and the most stubborn hardihood. Moreover he displays a goodly share of wisdom and cunning in disposing of his "flotsam and jetsam," and has other bits of maritime law-knowledge that have been rubbed into him by his calling, and which crop out, when occasion de278 


\section{THE WRECKER}

mands, to sometimes outwit and confound the keenest of the Cape Cod barristers.

For a week I had been with four of these rugged sea dogs, all of them seasoned with more than half a century (one of them seventy years of age), and yet when the winds are fierce, the fogs dense, the snows blinding, they are one and all on the qui vive for the signals of distress from some unfortunate coaster, or steamer, or full-rigged ship, as the case may be. One day I walked for miles along the beach, threading my way among a cargo of southern, hard-pine lumber of over two hundred thousand feet, which was piled high and dry on the sand from the wreck of the Altamaha, a Scotch vessel built forty-five years ago. This lumber has been sold since for $\$ 2.75$ and $\$ 2.25$ per thousand feet, but the purchaser had his hands full in getting it to the Boston market, and his brain puzzled to solve the question, not how much profit he would reap, but how much he would lose on the purchase.

Close by the island lay the wreck of Mr. Vanderbilt's famous yacht, Alva, whose walnut fixtures and trimmings were coming daily to shore. It took a contractor some time to blow her to pieces and remove the obstruction, the Government having awarded him the contract for about $\$ 9,000$, which was only half the amount asked by the next lowest bidder. As a working base for his operations the contractor brought a little steamer down from Brooklyn. I saw the boat 
under full steam, and she was so slow I mistook her for a stationary light-ship. The contractor commenced his work, and when the tide was at its lowest ebb he was able to get only about half an hour's work on the wreck each day, as it then lay in fourteen feet of water. It is not likely that he made a fortune out of the job.

The steamer, Cottage City, came ashore here, the vessel and cargo being valued at $\$ 130,000$. The owners of the steamer sent the captain of the lifesaving crew, who had given vital assistance in getting her off the shoals, the munificent sum of five dollars for each man of his crew. The captain promptly returned the donation with the assertion that he himself could easily afford to give his crew that much without seriously hurting his bank account. The owners of a small coaler that was helped off by the same crew at once sent the men $\$ 25$ each, which was a distinction with a difference.

I saw a vessel of 500 tons' burden that had gone to the bad on the Handkerchief Shoals, which are a few miles from the Island. She was laden with coal. A fleet of small craft made daily visits to the wreck, buying and laying in a generous supply of coal for the winter's fires of the residents of Harwich, Dennis and Chathan. The prices charged the boats varied from one dollar per ton to a lump price for what the dory, sloop, cat boat or yacht could hold. 
Some time since a vessel showed signals of distress off the Island, and in a moderate storm. The daring wreckers were soon aboard of her and found the captain, with his wife and children, anxious to be taken off. The vessel had five and a half feet of water in the hold. The captain was half owner, and as she was well insured he did not care what became of her so that she was beached, and the crew, with himself and family, taken off in safety. The wreckers, together with the life-saving service, manned the three pumps, got her under way and into the calm waters of the bay, where she was sold by the underwriters. The wreckers' share of the treasure trove was about $\$ 40$ per man.

Some years ago a vessel was abandoned here and when the wreck was broken up two huge plugs were found in her side below the water line. These showed conclusively that the captain, in order to reap the insurance, had deliberately filled her with water, and then, finding she was sinking too fast, had driven the plugs home so as to enable the crew to get ashore without danger.

One of the narrators of these tales of shipwreck waddles along with one leg bent out from him like a drawn bow. He has had it broken three times, and now, while it will bear his "heft," as he calls it, he can carry but little addition to it without severe physical distress. The first time it was broken he was aboard a 
shipwrecked vessel that he had agreed to stay by-all alone-while a tug towed her into a haven of rest. The wind was blowing a gale. The hawser being drawn so tight as to have little or no "bight," he was fearful that the strain might cause it to fray by rubbing on the sides of the "eye" through which it passed, and so part it. While he was examining it the iron plating of the eye snapped and crumbled like an egg shell under the strain. One of the pieces struck him on his leg below the knee, breaking it in three places. A consultation between the injured man and the captain resulted in the latter taking him into Hyannis, Mass., where he was driven to the station in time to take a train for New Bedford, the nearest place, in those days, to obtain efficient surgical aid.

The railroad service at that time was primitive, the time slow, and the track as rough to the crippled wrecker as a corduroy road. The journey to the cars lasted just eight hours, and during the whole of the time he was forced to hold his knee tightly with bis hands. The doctor who set it complimented him on his wonderful pluck, kept him in bed eight weeks and then sent him home with-as he described it-the "best bad leg" he had ever seen. In these days of anæsthetics and improved railroad facilities such an experience could hardly happen.

Among the Cape's quaint customs I find the old 


\section{THE WRECKER}

Scottish one known as "bundling." But this, like other of her quaint customs, is slowly yielding to the march of the newspaper, the telegraph, the telephone, and the railroad; I scarcely believed that the custom still existed or, indeed, ever had a foothold on this continent, but I soon found indubitable proof of it. "Bundling," you must know, is a method of courtship based on motives of economy, (the saving of light and fire). It is still practiced in Scotland though gradually dying out there, as increasing prosperity affords broader scope for comfort and less necessity for economy. 


\section{Brant Shooting}

This sport, well carried, shall be chronicled.

-Midsumar Night's DREaM.

So let me chronicle a week's sport_-"well carried," I think-on Monomoy Island. A week of atmospheric somersaults; a week of rain, snow, hail, sleet, thunder with vivid lightning, and extreme cold. And yet in spite of the exposure-twice a day wading a thousand yards to our shooting boxes, guided by stakes a hundred yards apart, while we couldn't see from one to the other through the fog or sleeting snow ; then sitting in the box, at times over our knees in water, the waves dashing over us and slapping down the back of our neck, and the thermometer hugging the freezing point,-I say, despite all this, it was a week that is fondly fastened in my memory; a week full of adventure and novelty; and a week during which we breathed any quantity of ozone, and had for our sustenance plenty of superbly prepared sea-food together with a superbly prepared appetite and digestion to handle it. It was also a week of total blank so far as any news of the outside world was concerned. No letters, no newspapers, no telegrams to side-track our attention or ruffle our tranquillity. For once business and the shop might go to 
the-well, "Hades." Song, story and jest held high carnival. Dull care was banished and his woeful face never permitted to enter the portals of the old clubhouse so long as we held possession. For one week at least he was a stranger, a melancholy tramp, jobless and with no abiding-place on the sands of Monomoy Island or the waters thereof.

"Hello! there's branters," said a native of Cape Cod, as we left the little, mixed freight and passenger train at Chatham, Mass., on an early April morning. "There be nine on 'em," he said, counting our noses by mental arithmetic; and he was right. There were nine of us, with guns, woolen clothes, rubber clothes, canvas clothes, oil clothes, leather boots, rubber boots, rubber hats, crates of onions, boxes of loaded shells, cases of canned goods, together with mysterious looking "stun jugs" and "sich."

Nine of us-from Boston, Worcester, Quincy, Dorchester, Florida and Philadelphia-all drawn together by the Freemasonry of sport, and the shibboleth was "Brant." The day before I left home I told a prominent merchant that I was going shooting for a short time. He asked what I expected to shoot at this time o' year. "Brant," I replied.

"Well," he said, "when I was a boy I used to shoot squirrels with a rifle, and became so expert that I could shoot them back of the head every time."

How far back he didn't say. 
"Well," I answered, "brant are much harder to shoot than squirrels, for they run faster than rabbits and are much bigger." "Well, I declare," he said, and then relapsed into silence, perfectly satisfied that he knew all about it.

For the information of this Philadelphia merchant I will say that the brant is smaller than a goose, and at this spring-time of year is on his way northward, merrily helped along by hundreds of guns belching forth No. 3 to No. 1 shot from all sorts of innocent looking shooting boxes surrounded with decoys, both artificial and natural.

It is a bird of beautiful plumage and graceful form ; plump and fat, swift of wing and wary and suspicious of anything and everything that bears the slightest semblance of danger. There is also a mystery surrounding it which has bothered the scientists for ages and is still bothering them; namely, the whereabouts of its breeding habitat. The late Professor Spencer Baird worried himself more, perhaps, than any other savant over this undiscovered territory. No living man, it is said, has ever seen the nest or egg of the brant, and no matter how far explorers have forced their way northward the brant has always been seen winging on still further north. Therefore the Monomoy guides-some of whom have grown gray in the pursuit of "brantin" "-claim that there surely must be an open Polar Sea where the weather is 


\section{BRANT SHOOTING}

warm enough to hatch out their eggs, and where food is plenty and nutritious, for they come down in the fall of the year fat and sleek as a pullet. The young birds come south strong of wing and as cunning aswell, I might say of them what Buckingham said of the little Duke of York: "So cunning and so young is wonderful!"

Monomoy Island lies off the mainland in the ocean a few miles from Chatham, Mass. Between the island and the mainland the succulent sea-grass (the favorite food of the brant) waves gracefully to the gentle swell of the tide or the fierce northeaster-which, by the way, has been blowing a gale since we arrived.

The stretch of sheltered water here is large enough to leave the birds plenty of room to move around in swinging columns without coming within range of the sink boxes; and it is only when the tides and winds are favorable that the birds are brought within the line of danger. The Monomoy Branting Club-the only club of the sort, I believe, on the continent-has a couple of comfortable houses built on a bluff or dune. It also has artistically constructed sink boxes, placed at the most favorable points, and a large stock of wooden decoys. Live brant with clipped wings help to lure their kindred into danger, and with as much apparent satisfaction and enjoyment as the setter dog takes in flushing grouse or quail. The club is formed mostly of Eastern gentlemen and all of 
course, are enthusiasts in sporting. Their number is limited to twenty, each member being entitled to invite one guest. Four members only are permitted to be here at one time, and, as the shooting lasts five weeks, each set with their guests have one week's fun. At dinner in the little hotel at Chatham, we met the party, who had preceded us, returning to the "Hub" with seventy-four brant, bronzed cheeks and ravenous appetites.

Four guides are engaged by the club. They are men who thoroughly know the habits of the birds, understand the tides and currents and handling of boats, and also know how to shoot.

One of them has been continuously at the business of "guidin"” for thirty-one years. During all that time he missed only two days-one when he attended a funeral and the other when he had to go to court. The care of family, the tender offices of friends, the seductions of courtship, the excitement of the play or the circus-none of these has any allurement for the weather-beaten, blue-eyed and kindly men when once the branting season opens. During the rest of the year they earn a precarious living by fishing and wrecking. They watch the shifting sands, the gloomy fogs and the blinding snowstorms with earnest solicitude, for this is truly a dangerous place for the unwary mariner. During a recent winter the fine steamer Cottage City, running from Portland, 


\section{BRANT SHOOTING}

Me., to New York, struck in about fourteen feet of water. She held fast until thousands of boxes of merchandise were thrown overboard. Then with the aid of a tug and a high tide she was gotten off, and without rudder or stern-post was towed to New York.

Our friends, the guides, lamented the fact that most of the jettisoned cargo floated out to sea; but the remainder, which was weiglity enough to sink, they grappled in fifteen feet of water, bringing their find to the surface and shore. Of course, some "odd" lots were brought up. Among them was a case of 2,500 little boxes of split, leaden bullets for fish-line sinkers and several cases of white, flinty rock, consigned to a Trenton pottery. The wreckers were much out of heart about the latter because of their weight and also because no one could tell them whether they were worth the freight to Trenton or not.

These wreckers, branters and fishermen live a happy life and are as full of content as an egg is of meat. No fluctuations in stocks; no frills of fashion;-in fact nothing under the sun or over it can knock the bottom out of a branter's content, give him but the favoring tide and howling gust that bring the brant in plenty. to his decoys. It is this hope that warms his imagination and cheers his heart, for its realization is apt to fill his pocket with a goodly share of the coin of the realm. 


\section{The Quaint Cape-Codders}

Ah, what a life were this !

- HeNry VI.

ON my trip to Cape Cod, via the Old Colony Railroad, I saw, on every hand, signs of the stern difficulties that beset the Cape-Codder and make his path through life a rough, as well as an unprofitable one to travel. His comforts are few and hard to get. He has to be satisfied with rude shelter and ruder fare, and to secure even these he is often compelled to wade his "bog of Adversity." Yet he doesn't lose heart, but shoulders his bundle of troubles philosophically and plods along his miry way. Now, if Hamlet had but owned a little of this Cape Cod philosophy he would never have sprung his crazy question on the world whether it is better "to be, or not to be." Nor would the "arrows of outrageous fortune" have bothered him gravely. He would have paid as little heed to their whiz about his ears as a tough-skinned native pays to the buzz of a Jersey mosquito. The "sea of troubles" that swamped the Dane and upset the craft of his annotators were trifles compared with those that buffet the Cape-Codder in his struggle for existence on the barren dunes and pine forests and cranberry bogs that make up the topography of his habitat. We can readily read in his face the story of poor soil and scanty crops and battles with the winds and storms he can't 


\section{THE QUAINT CAPE-CODDERS 291}

escape in his chase after the finny tribe, or in his other laborious pursuit of cranberry raising.

Old Colony Railroad stock is partly held by the natives of Cape Cod who look upon it as the great railroad of the world. It once had a custom of giving to its Cape stockholders a free ticket to Boston and return, on the occasion of the road's annual meeting in that city. A man owning one share had the privilege in common with his more wealthy neighbor; therefore, if a Cape-Codder had five shares he arranged to have them entered singly for each member of his family, so all of them might make the annual tour to the "Hub." As time went on and the control of the road changed, this free excursion was abolished, and many and loud were the grumbles of discontent among the people at its abolition.

I have more than hinted that the average CapeCodder is not in that comfortable condition which the world calls "well-fixed." In fact, he is very much the other way-chronically hard-up. His church-mouse poverty has been the theme of many a quip, and the following one will prove that while the soil of Cape Cod may be too poor to grow a mullein stall, it is rich enough to raise a poet:

"There was a young lady of Truro

Who sighed for a 'hogany bureau

But her pa said 'Great God !

All the men in Cape Cod

Couldn't pay for a 'hogany bureau!' "' 
But "to return to my mutton," which is brant,-not mahogany bureaus, I will now describe a sight that will linger in my recollection as an exhibition of the wonderful instinct and weather-wisdom of migrating sea-fowl.

For days strong nor'easters had blown fiercely, accompanied by snow, sleet, rain, thunder and lightning ; and through these the brant could have made but little headway had they tried to proceed on their jour. ney northwards. But they didn't try. They knew better than Old Probs what the weather was going to be. There came a lull in the storm, a fog set in, and the brant congregated in long columns, flapping their wings and making the most deafening outcries. Our guides said: "The birds are preparing to start. The weather will settle by morning." But, after the fog, came a furious gale with vivid flashes of lightning, loud peals of thunder and a down-pouring of rain. This condition of affairs lasted all night, and for once our confidence in the brant's wisdom and judgment was shaken. It need not have been. The next morning the sun arose bright and warm, with a southwest wind, and away went the brant, flying northward. First a series of swooping circles, rising higher and higher in the air, a pause, and then off they go by the thousands, in flocks of from three to five hundred, all carefully marshalled and efficiently led by some old gander who will allow his followers no rest for the 


\section{THE QUAINT CAPE-CODDERS 293}

soles of their feet until the Bay of Fundy or Prince Edward's Island is reached.

Then we saw other flocks, equally large, come from the south and stop to rest and feed before proceeding on their journey to their mysterious and unknown resting-place.

As the one aim, the one conversation of the whole nine of us was the pursuit of brant, we became saturated with the theme. We thought brant, dreamt brant, mused brant, discussed brant, and, perhaps, if we swore at all, would have sworn brant. I have known a poker-player with three aces in his handand possibly another up his sleeve-to suddenly throw down his cards and exclaim: "I want to shoot a brant!" showing very plainly that poker was not the kind of game he was after. I have watched this same chap lying upon his bed and tossing wearily from side to side, while between his snores would come the whispered wish: "I want to shoot a brant!" And he would keep up these whispers until he was in the faroff land of dreams and probably banging away at the birds to his heart's content.

But what about our Cape Cod luck? Did we bag many of the brant? Yes, we all got our share. Even our poker-player bagged enough of them to fill the measure of his dreams and satisfy the demands of his heated imagination.

The cooking at the clubhouse on Monomoy Island 
deserves a warm word of tribute. There are two chefs who revel in producing dishes peculiar to the Cape and Island-dishes which are at once enticing, nourishing and appetizing. Some of their productions defy my power to describe; but I will long hold recollections of their huge bowl of delicious, stewed scallops, their quahog stews, quahog pies, quahog fritters, clam chowders; steamed clams, boiled clams, fresh boiled cod, fish balls with the accompaniment of thin slices of raw Bermuda onions, fresh cucumbers, the finest of butter, Java coffee, and water that would make any city-bred man's heart thump with joy if he ever got a taste of it. Did our gastronomic quarters have any difficulty in accommodating such a crowd of delicacies? No, not a bit. Thanks to a ravenous appetite and a good digestion to wait on it, we found a stomach for them all. Nor did they stir up any miclnight regrets. Think of that, " $\mathrm{O}$ ye of little faith" in the virtue of outdoor sports. Think of it, nor wonder that when we turned into our bunks sweet sleep at once embraced us-sleep without bromides or hoppillows or any other soporific spur-sleep that bore us through the roar of the surf and the rattle of Jove's artillery, until Alonzo, the guide, awoke us with a knock and his customary warning: "Gentlemen, gentlemen, the tide's aflowin' in!" 


\section{A Wary Bird}

We'll make a solemn wager on your cunnings.

- Haylet.

A MAN, to be successful in brant-shooting, must be a sportsman of the most enthusiastic type and a fair shot. Moreover, he must possess a good constitution, plenty of patience, and plenty of ability to defy cold, wet and exposure. He must expect many disappointments and a great deal of waiting, for the birds are so wary and so seldom deceived it is rarely he will find them within the range of his heaviest charges of powder and shot. When the chance of a shot is obtained and he downs his bird the excitement is over quick as a flash and he wonders how it all happened. Let me describe how it is done.

During the early spring the guides have sunk boxes large enough to hold three men. The boxes are placed sometimes out on the bay in shallow water, with hundreds of wheelbarrowfuls of sand piled around them at low tide, the sand being covered and neatly fastened down with a sail cloth, so that the rushing tides cannot carry it away. This is to represent a sand bar. The other plan is to fix the boxes on some jutting point of land in the bay, always using plenty of sand, behind which the gunners are to sit with bowed 
heads, but with watchful eyes and ears. Out in front of these boxes wooden decoys are fixed on a framework like the letter $V$, five on each frame, all strung together, so that they turn with the tide and wind and look natural enough to deceive the oldest gander in the flock.

Then two gunners with the guide wend their way to the boxes when the tide is flowing in, the gunners encased in hip rubber boots, two or three pairs of stockings, a heavy suit (flannel shirts, sweaters, orercoats), and lastly an oilskin suit, if the weather be rough. The gunners get in the boxes, arrange their pipes and shells and bail the water out, while the guide takes from a basket a pair of clipped-wing brant which he deftly harnesses together like a span of horses. The yokes, made with leather thongs, are put on their feet, not their necks. They are allowed to swim or wade out quite a distance, being secured by a cord which is kept on a reel in the sink box.

The particular part these birds are to perform (when the brant are flying or swimming anywhere near) is to flap their wings and "honk" their wild relatives into danger among the decoys; and it is amazing how intelligently they do their work; how they get away out of range when the wild birds are being covered by the deadly breech-loader, and how they chatter to themselves with seeming satisfaction when the battery has been unmasked and the fallen 


\section{A WARY BIRD}

birds retrieved. When all is ready the guide gets into the box, and then the trials of endurance, patience and expectancy begin. There is no lack of birds in sight-thousands of them-and their cries at times are deafening, but they keep prorokingly far enough off to make you feel as if your head must never again be raised. You soon get cramped and numbed with the cold wind; and maybe have rain, or snow or sleet blowing and pelting in your face. But you must not get up.

Once I sat in a box for five hours, and during the whole of that time the rain, snow and sleet were driving into my teeth, while to vary the monotony the water from the high tide would now and then wash over my back and down my neck. Yet I waited paitently for my reward and got it. Up like a flash and within range came five birds, flying down the wind with the speed of a carrier pigeon. We got a shot apiece; three were left behind, while the other two were soon miles away. Our long wait and exposure were forgotten. We said: "How did those two birds get away?" "They must be crippled!" "Watch them!" "They're going down!" "No, they're not!" "Yes, they are!" and so on, but the birds were not ours, that was sure.

And thus you never know when out of the haze, or the clear sky, like a meteor from behind you, or straight on, a bunch of birds may come that have 
been deceived by your pair of live honkers and your wooden shams. Or again, a flock may be feeding and unconsciously drifting with the inflowing tide towards your box, occasionally giving a quick, suspicious look, swimming back a little, then onward again. But you, too, must be wary. To raise the tip of your hat above the brim of the sand-bank or to get up to stretch yourself is tantamount to a speedy departure of the "mysterious bird of the North." Therefore it is the man who can stand this sort of work the best who is likely to make the biggest bag. A great deal depends upon the wind as well, for if the currents of air should be blowing off shore there is not much chance of successful shooting, as the wind constantly drifts them away from the decoys, while they are feeding; and if any should be shot and drop down at long range they are apt to get out of reach before they can be retrieved.

We were seven days on Monomoy Island and had a fierce nor'easter blowing nearly the whole time. What success we were blessed with (thirty-six brant), was due solely to lots of patience and perseverance against hard conditions.

But the sport compels you to be out in the open air, to inhale the ozone and the ocean breezes-those twin benefactors that bring to the hunter his proverbial appetite. And, oh that appetite! You have it and a digestion to wait on it that might tackle a peck of 
dried apples without getting out of order. There is another thing you have which is not to be sneezed at - the gratification of knowing that with your trusty gun, your hidden retreats, your enticing decoys and your unwearied patience you are more than a match for this the grandest and most wary of all game birds.

\footnotetext{
"Nor on the surges of the boundless air, Though borne triumphant, are they safe; the gun, Glanc'd just, and sudden, from the gunner's eye, O'ertakes their sounding pinions; and again, Immediate brings them from the towering wing Dead to the ground; or drives them wide dispersed, Wounded and wheeling various, down the wind."
}

This season the brant arrived in great numbers at Monomoy as early as February, but finding their natural food-the eel grass-sealed in ice, they were forced to wing their way backward, after many attempts to get at their feeding grounds; the cold weather thus compelled them to make trips of hundreds of miles to the southward before they could obtain their sustenance. But they are grand "flyers" and a few hundred miles of flight is only a morning's "constitutional" for them, and they don't seem to worry the least bit about it. As soon as the ice melted and their favorite eel grass was exposed to view, then they arrived in countless numbers. Some say that between the fifth and tenth of April more birds were at the Island than ever were seen before 
at one time. But the wrecks and wreckage there drew all manner of sailboats to the scene to get coal and lumber, and thus the birds were continually disturbed in their feeding. They were occasionally fired on at long range from these sailboats and this harassed and frightened them, leeping them for hours on the move. This, together with unfarorable winds and storms, reduced the total bag for the season to one hundred and ninety-seven brant. Such was the result of the work of seven weekly parties, aggregating fifty-seven sportsmen, with an average of eight to each party, and, as our party bagged thirty-six, we had no reason to complain. Of the one hundred and ninety-seven killed, one hundred and three were young birds and ninety-four were old ones. This proportion of young birds ought to have made the shooting better, as the latter (in the language of the president of the club), "are less wary, more social and more easily decoyed, and will carry off less lead than the tough, old birds; and then it often happens that the elders are led by unsuspicious youth into places of danger where it would be impossible to coax them when separated; therefore the presence of so many juvenile visitors is always a joy to the heart of the sportsman." 


\section{Quail Shooting in North Carolina}

One that loves quails.

-Troilus and Cressida.

Is a lone car, hitched to the end of a freight train, sat two individuals-a fellow-sport and myself-taking a trip through the "land of moonshine and fried things," in search of quail.

The train halted at a small station, some twentyfive miles from Greensboro, where a wagon should have been in waiting to carry us on our way to a tobacco plantation seven miles distant.

It was " the top o' the morning" when we stepped out on the platform, and a very frosty "top" it was, too. No vehicle was there to meet us, nor was there any in sight, or out of it, that could be hired for love or money. Our only resource, therefore, was to stand and shiver and "wait for the wagon." An hour passed and we began to think it had no intention of coming; but just as our last drop of patience was about oozing out, the wagon arrived drawn by a pair of mules, and driven by an old man whom we soon found to be a fellow of infinite gab, if not "of most excellent fancy." He had two companions seated behind him, one of them being his son-an overgrown hobbledehoy of fourteen-whose name was Tom. 
Now, there was something remarkable in the top part of Tom's make-up. His face was spattered with freckles of various sizes, and illuminated by a grin that backed the corners of his mouth against his ears and threatened to push them off their base. He had a squint in one of his eyes, and both of them were coated with a milky film, which gave his mug the expression of a boiled mackerel. Over all was a wiry mop of red hair, tumbled and tangled together in a manner that would trouble a comb to travel through.

His star feature, however, was his grin, and he never allowed it to slack up. If it showed a tendency that way, he would spur it on by poking fun at the "old man," as he called him, pushing his hat over his eyes, tickling his ears, and by divers other pranks of which he seemed to have an inexhaustible supply.

The other lad was only an apprentice on the farm and bound until he came of age. His clothes were shabby and hung about him in a way that suggested his inside to be as shabbily cared for as his outside.

Our journey of seven miles consumed two hours, and during all that time the "old man's" jaw never faltered. He gave us a complete history of his life, domestic and otherwise. He boasted of being the father of eight living children and one dead one; while his occupations were almost as numerous as his children. He was a helper, a driver, a ploughman, a tobacco curer, and the general factotum of the planta- 


\section{QUAIL SHOOTING}

tion, which consisted of six hundred acres of land. For all this work he received the princely sum of one hundred dollars per annum. Then he entertained us with many tales of the moonshiners-those defiant breakers of the revenue law who ply their secret and perilous calling in these regions. Two days before our visit one of the best-known of the moonshine fraternity had been shot in cold blood by a man who had informed upon him and who alleged that in consequence of his act his life was not safe, and therefore he killed him. The murderer was even then out of jail on $\$ 500$ bail, and our driver predicted that if he lived to be tried he would surely get off; but he "allowed it war more likely he would be killed before the trial was reached."

Then the old fellow told us the story of a fight that had taken place the previous evening, and which ended in the possible death of one of the participants. "You see," said the old man, "one of the fighters is a chap known around these yer diggings as 'Red Angel.' He's a tough cuss to tackle, but when he got through with that scrimmage, I tell you, stranger, though there was plenty of red about him, he didn't look much like an angel. Why, sir, he was so battered, and hammered, and cut and slashed that his best friends didn't know him. I never did think much of that fellow, no how, and I'm darned glad that for once he got a bellyful of his own med'cine." 
On the way to the plantation we had our first experience in plucking and eating some rich, ripe persimmons that hung upon their trees at the roadside. A thoroughly ripe and frost-nipped persimmon is always pleasing to my palate, but these were particularly so and met with all the appreciation they deserved.

The portion of the country through which we rode is decidedly hilly, with deep ravines bordered with all sorts and conditions of briars, blackberry bushes, poison ivy and wild grape-vines. These afford rich cover for rabbits, while the big fields of wheat stubble and cow peas that clothe the tops and sides of the hills are apt to lure the quail to roost and feed there. And they do roost and feed there to some purpose, for we found them as fat as butter, and so plentiful that we were able to flush from twelve to fifteen coveys a day.

We brought with us on our trip a supply of bread sufficient to last a week; also some of the best tea and coffee. We did so as a matter of discretion, for our ears had been filled with queer stories of the "fried things" and the curious liquids masquerading as "tea and coffee" that lie in wait in this region to astonish and upset the nerves of a civilized stomach.

We reached our destination in the early afternoon and were pleased to meet there a third member of our party-a young dentist. Men of his profession, I be- 


\section{QUAIL SHOOTING}

lieve, are reckoned among the world's necessary evils, making their living out of the miseries of other people by rasping their grinders, filling their mouths with rubber dams-and possibly damns of another sortand boring into the bowels of their molars. However, my friend had deserted this occupation for awhile to indulge in the more congenial one of quail shooting, and when we arrived we found him and his dogs awaiting us.

After taking a hasty dinner of boiled cabbage and "fried things," we started for the fields; and a little later the battery of guns shook the air, while the whirr of the swift-flying quail greeted our ears and started our blood on a frisky gallop through its channels.

Though the birds were there in abundance they were as wild as Bob White knows how to be when he is pointed at and shouted at and shot at by every man in the country who can get hold of a gun. Down in this region the whole of Christmas week, as well as the remainder of the year, is Christmas, and everybody, whether he is anybody, or not, takes a grand holiday. and starts on a hunt for rabbits, squirrels, wild turkeys, quail, and the fat opossum. Never in all my "born days" have I seen such an heterogeneous assortment of guns. Guns tied with wire; guns wrapped with leather thongs and twine to keep them from falling apart; old muzzle-loaders whose rusty barrels were loaded with peril for the man bold enough to fire them; 
single and double guns with balky hammers-in fact a collection of real curiosities that a dime museum manager with any enterprize ought to snap at. And then the dogs_or "dawgs" as they call them in this region-their diversity is even greater than that of the guns. Hounds of all kinds, some of which would run rabbits and not bother with squirrels; others that would tree squirrels and not trouble their heads with rabbits; opossum dogs, good, bad and indifferent; pointers of the first-class and others of no class at all. But all were in demand and none out of use.

I saw one party of gunners consisting of seventeen men and boys, colored and white. They had five hounds with them and were in pursuit of a poor, lone rabbit. There was a good deal of ammunition wasted, but the numbers of the attacking force left a slim chance for the rabbit, and it was killed.

I saw another party that had treed a gray squirrel in an old poplar. The little fellow, in his endeavor to get out of the way of danger, had climbed to the top of the tree-a very tall one-and there he sat, with his tail curved gracefully over his back, while he looked down on the enemy who were banging away at him as rapidly as they could fire and reload. Their bangs, however, didn't upset either himself or his equanimity. When I left they had fired twenty shots at him; still the little fellow sat there with his tail 


\section{QUAIL SHOOTING}

over his back, and, unless the enemy have been reinforced, he may be sitting there yet.

To return to the quail; no wonder they were wild. No wonder that when they were flushed they flew like bullets, and flew far. But we got a goodly bag, and when it was too dark to shoot any more we climbed the hills to the farmhouse, hung up our birds, and, hungry as hunters ever were, sat down again to boiled cabbage and "fried things." We were early to bed. Eight of the clock found us sound asleep, and at daylight we were again up and doing.

The plantation on which we were domiciled had been tilled and planted with tobacco and other crops for more than a hundred years, and the soil bids fair to last for a hundred more, notwithstanding the bad repute that tobacco has for its exhaustion.

It is a little strange that the moral and physical ailments of the people hereabouts are so inconsiderable. "Preachin"" is a physic they don't seem to relish-a dose of it once a month being all that they think it necessary for them to swallow. Their bodily ills they entrust to a pair of doctors whose shops are far away-one of them seven, and the other eleven miles. These Esculapians have a sharp eye for business and conduct it strictly on the "spot cash" principle. One of them charges $\$ 2.00$ and the other $\$ 2.50$ for each visit, and they insist upon having their fee in adrance-a rule probably based on their knowl- 
edge that it is easier to get money out of a live man than a dead one.

Perliaps the liveliest man in this moonshine district is the moonshiner himself. And he has need to be, for it requires an uncommon amount of liveliness to carry on his business and keep out of jail at the same time. The whiskey he makes is pure, without doubt, and white as water. He sells it at a dollar per gallon, but it isn't every one that can buy it; not because the price is out of his reach, but for the reason that it isn't every one the daring distiller can trust. The thirsty customer must be a man whom the moonshiner knows to be friendly, otherwise he will have to "go dry," or get his corn juice from a legitimate quarter.

We had one week of hard work-if hunting can be called work-and then, loaded down with quail, gray squirrels, and a big box of persimmons, we bade farewell, but not without regret, to the realm of the moonshiner. We envied the happiness of the quaint people with whom we had dwelt during our trip, and almost wished that Fate had shaped our own existence in the same mold. They are strangers to sorrow and sadness, while cares of any sort they know nothing about. They have no telegraph, nor telephone, nor even a mail boy to ruffle the smooth current of their lives. Their wants are few. Good-will, goodfellowship, the open air of heaven, plenty of good 


\section{QUAIL SHOOTING}

water and an occasional sip of "moonshine" are all they ask of this world; and when the weight of years, rather than disease, crowds them out of it, they leave behind them an apt illustration of the old proverb: "Contentment is better than riches." 


\section{"Trout Tickling" and an Old-England Blizzard}

Here comes the trout that must be caught with tickling. -TWELFTH Night.

Up in the extreme north of England there is a great stretch of moorlands, with here and there a plantation of fir trees. Weardale, in the county of Durham, is situated in this region, and among its hills the River Wear has its rise, rushing swiftly down its rocky course to where it enters the sea at the great shipping port of Sunderland, and, on its way, passing the historic city of Durham with its grand cathedral, and the town of Stanhope where the learned bishop of Durham, Joseph Butler, lived and wrote his "Analogy of Religion."

The Wear is a stream well-fitted to stir up a man's love for romance-if he has any-and to feed his fancy for the musty doings of Antiquity. The river flows through a limestone region abounding with rich veins of lead ore which have been worked with profit from time immemorial. The region also has large coal deposits, and these, too, have been worked since the days of Julius Cæsar and are still inexhausted.

All this is very true. But suppose "the man with a love for romance" happens to be a "sport"? What cares he for the musty doings of Antiquity? 


\section{“TROUT TICKLING "}

Or what is there about ancient mines of lead and coal to interest him? He takes as little stock in themwith all his fondness for Wall Street "flyers"—as he does in the moon's mines of green cheese. No; the River Wear must boast of something else if it would rouse his love for romance and keep his interest awake. Well, it does boast of something else, and something that will surely do both-it is a favorite resort for the speckled trout and salmon.

In England these fish are protected by the rigorous enforcement of the poaching laws, and woe betide the man who dares to cast a line within the sacred waters. Hence it is that the poacher trusts to his dexterity in "tickling" the fish, rather than attempting to capture them with rod and line, and run the risk of getting the hook of the law in his own gills. And the poacher's dexterity is rather marvelous. I met one of these old fellows-their stories are pretty much alike-who assured me that never in his life had he caught a trout or a salmon with rod and line; but he had "tickled" many a one into his pocket.

And this is how the "tickling" is done. The fish are watched working their way up the shallows and rapids. When they come to the shelter of a ledge or a rock it is their nature to slide under it and rest. The poacher sees the edge of a fin or the moving of a tail, or maybe he sees neither; instinct, however, tells him a fish ought to be there, so he takes to the water 
very softly and carefully and steals up near the spot. Then he kneels on one knee and passes his hand, turned with finger's up, deftly under the rock until it comes in contact with the fish's tail. Then he begins the tickling with his forefinger, gradually running his hand along the fish's belly further and further towards the head until it is under the gills. Then comes a quick grasp, a struggle, and the prize is wrenched out of his natural element, stunned with a blow on the head, and landed in the pocket of the poacher.

I was born very near this classic stream-not more than a stone's throw from its banlss-and as two of $\mathrm{my}$ male relatives were out-and-out sportsmen, many a lesson I received from them in my early days. I recollect a great snowstorm which buried that section of country in drifts that would make the much-vaunted piles of our American blizzards seem puny and insignificant. The distance from ocean to ocean at this point is only sixty miles, and the fierce winds sweep down the English Channel on the one side, or from the German Ocean on the other, and drive the snow before them with frightful velocity, burying landmarks, houses, fences and even trees. It was a few days before Christmas, in 1852 , that a great storm visited us. I was seven years of age, and therefore the incidents attending it made a lasting impression. We lived in a low, two-story house at a place called Ling Riggs, directly on the moors. (Ling is another 


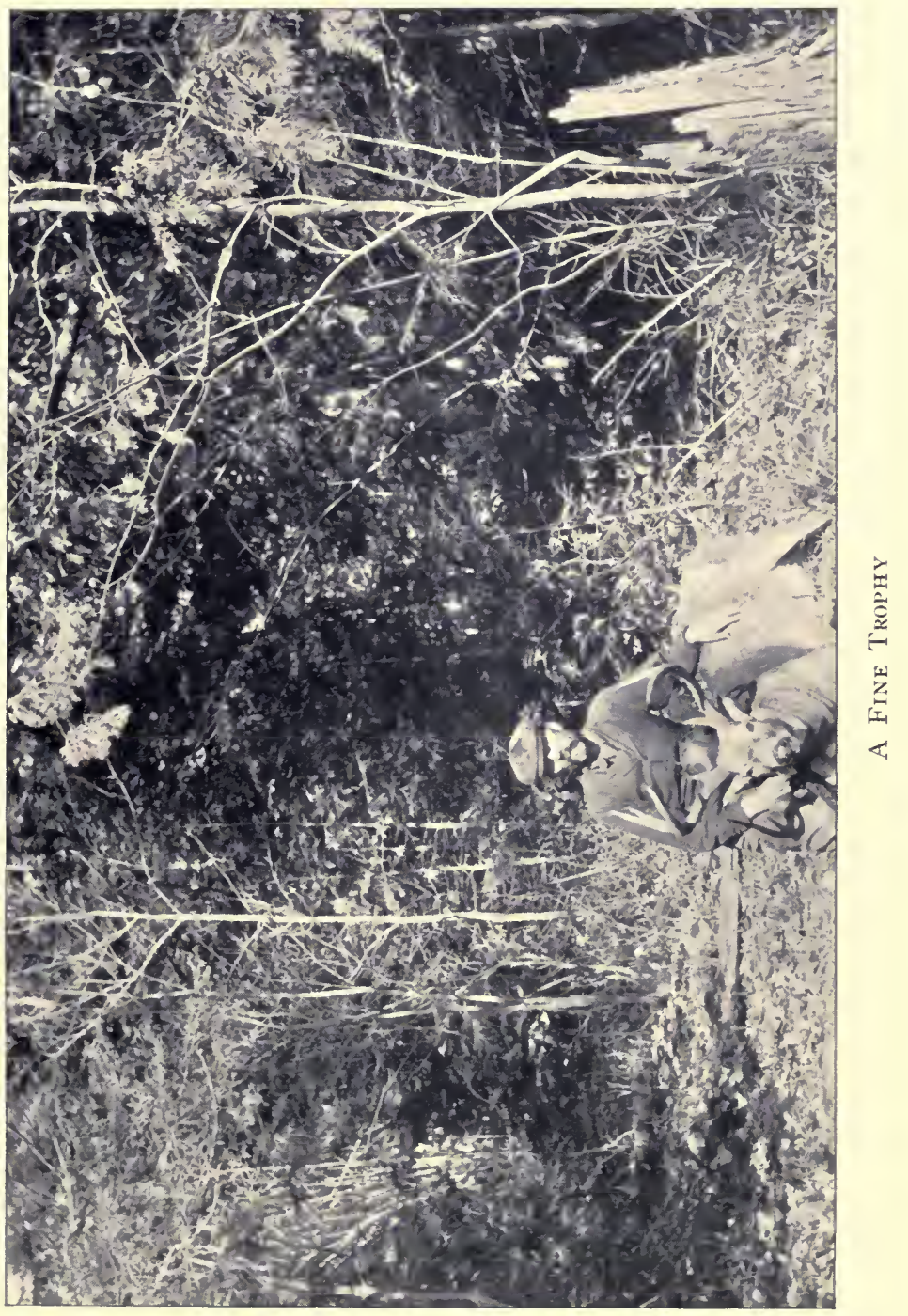



name for heather, and Riggs another name for rocks.) Our house was so completely buried in the snow that a tunnel had to be dug through the drift to the nearby road. Through this road a channel had been dug by the people to enable them to make connections with the village of Ireshope-Burn, a mile or so below. After the storm had ceased the temperature rose and then fell again, thus solidifying the snow, so it would alnost, but not quite, bear a person's weight.

I had been pent up, a veritable prisoner, for some days by this snow blockade, but on Christmas Day the sun shone out bright and warm, and, with or without parental consent, I forget which, I slipped out of the house, through the tunnel to the road and over the road to the moors beyond, rejoicing in the thought that I couldn't get lost, because I could surely come back on my own tracks. So I jumped and flounced in the snow, that was deep enough to bury all the stone walls and hedges, and the novelty of getting over these without feeling or seeing them was rather delightful to my young brain.

But look! "What's that struggling in the snow ahead of me? As I live, a big hare, and almost exhausted !" The sight nearly robbed me of my breatl. I had a good deal of the sportsman's blood in my veins, even at that early period, and it danced through them in such a lively fashion I forgot all about the poaching laws and went for "the timorous flying 
hare." The chase was a lively, though a short one. I soon caught her ladyship, and taking off my coat wrapped it around her to quiet her struggles, and then started home with my prize. My father was nearly as much excited as myself, for meat of any kind being scarce in those days, a big fat hare was a luxury worthy of considerable glorification. While he was holding it up and admiring it and smacking his lips at the prospect of a coming feast, my grandfather came in. He was a Methodist preacher and a very strict one in his regard for all manner of laws. Without delay or ceremony he began to lecture my father for harboring the hare and encouraging "his lad" in poaching. The lecture was a long one, and withal so forcible, that, when it ended, my father opened the cottage door and gave the hare her liberty. I noticed, however, that he looked longingly in the direction of his vanishing feast, and seemed so full of his disappointment that I came near forgetting my own. But I didn't. My grandfather soon left for his home, fully satisfied that he had done his duty in saving his sonin-law and grandson from an infraction of the poaching law. As I have said, my young blood had a good deal of the "sport" in it, and I couldn't for the life of me see what harm I had committed. In fact, I was so convinced that I had done no harm, that I was willing to do it again. So as soon as my grandfather was out of sight I slipped out of the house and took up the 


\section{"TROƯT TİCKLING"}

hare's trail. This time I had a hard run for it, but my youthful legs were swifter than the hare's, handicapped as she was with snowdrifts. Catching her and wrapping her once more in my jacket, I carried her back to the house. There was no compunction or hesitation on my father's part now. He promptly killed the hare, and the quiet tip was given to a few of his friends, and invitations to the feast were extended and accepted with the greatest secrecy. I was the hero of the hour, and whether my grandfather ever knew how or why I deserved my heroic honors I cannot say. It matters little now, for he has lain in his grave for more than two score years, but this I can say, that the hare and the chase and the lecture and the game supper and the big snowstorm-all are locked in the coffer of my memory and tight enough to stay there. 


\section{A Dangerous Ride}

Now, I spy a danger.

- King Lear.

No man can reasonably hope to get through this world without sometimes losing his way among its thorns or bucking his head against its dangers. The latter are plentiful enough to keep him on the dodge from those he sees, while he holds a wary eye at the peep-hole of discretion for those that may be lying in ambush. It isn't strange that he follows the advice of the "tricksy Ariel":

\section{"If of life you keep a care, Shake off slumber and beware."}

Nor will it be strange if he continues to follow it, so long as life is so sweet and death is so bitter.

Life is sweet? Yes, and quite as sweet to the sport as it is to other people. I have had cause to be conscious of its sweetness, and sometimes to be a little anxious for its safety. At one of these times I chanced to be traveling on a single-track-railway train which was rushing toward another coming in an opposite direction. On a well-regulated road, guarded by well-regulated telegraph operators, anxiety might have been groundless; but before I get through with my story it will tell the reader that a telegraph oper- 


\section{A DANGEROUS RIDE}

ator, when he falls into the clutches of Cupid, is as unreliable as any other mortal in a like fix. His appetite is so squandered on his "duck" he has none of it left for orders, calls, messages, and instructions ; and, like a watch without a balance wheel, all his regulations are knocked into a cocked-hat.

Now for my story.

My son and myself were out in Northwestern Pennsylvania, rabbit and pheasant-hunting, taking with us a couple of beagle hounds for running the rabbits. We had reached a station where three railroads intersect, and we soon discovered that no two of them work together in harmony. If you arrive there at any time of the day and expect to make train-connection with one of the other roads you will be disappointed. Their managers, however, all harmonize on one point-" the way to run a railroad is to let one man do the work of six." There is a frame station with one ticket seller who acts as station agent, baggage-master, telegraph operator, signal man, freight agent, and, moreover, is expected to do anything else that is waiting to be done.

There is another frame house a short distance away in which a section boss lives with his wife and family. The boss is a man of some enterprise and he confines it chiefly to squeezing a livelihood out of the passengers by feeding them on "a square meal for a quarter." A big sign is posted in front of his establish- 
ment informing the passenger of the gastronomic bargain that awaits his hungry stomach. On a previous visit to this station the boss's sign was the first thing that struck our eye, and we ventured to "try on" one of his "square meals." It was a misfit. Our innerman's grub department was seemingly too round to accommodate his four-cornered meal, and it swore emphatically, that it would thenceforth stick to the round meal, clean and understandable, and avoid a "square" one made of dirt and mystery.

It was early in the afternoon when our train reached this junction, and the train, with which we were to connect in order to reach our destination, would not be due at the station for some four hours. In the meanwhile hunger, which waits for neither time, tide, nor railroad trains, began to show its teeth and gnaw at our inner walls. We let it gnaw awhile - rather than worry our stomach with any quadrangular experiments-and then satisfied it with a meal of apples and raw turnips. The dainty jaws of a city chap may turn up their nose at a dinner of apples and raw turnips, but they will turn it the other way should they ever become the property of a hunter. The "sport's" hunger is sometimes his only sauce; but it is a good one, and with its aid he might possibly make a satisfactory meal of boiled cobbles and sole-leather. The country about us looked a likely spot for rabbits; and the beagles, too, appeared to think so, for 


\section{A DANGEROUS RIDE}

they were tugging at their chains in the baggageroom. So we asked the youth in charge of the station if he would look after our baggage while we gave the dogs a run. He consented, and shouldering our guns we started down the track with the dogs.

We had walked perhaps half a mile, when the hounds struck a rabbit trail and were off in full cry. Just then the youth, with whom we had left our luggage, joined us, saying he "Couldn't resist the temptation to go along with us no how." He had locked up the station and run down the track after us with such speed that when he arrived he was entirely short of breath. He sat down to rest, but in an instant was on his feet again, and, with a "By thunder!" ejaculation, started to run back toward the station, jumping the cross-ties, and altogether acting as if he were troubled with "rats in his upper story." There was something wrong, but as we couldn't guess what, we gave up the problem and went on with the hunt.

The shades of night now began to fall and we returned to the station. The youth was there, and as he saw that we were shivering in the chilly air, he invited us into his ticket office where it was warm and where we might stay until our train arrived.

"Why did you leave us in such a hurry?" I asked.

"Well, you see, bein' Saturday night, a special train for workmen from the West was due here at a certain time, and I had orders to hold her until another train 
passed from the East. I was so anxious to be along with you that I forgot all about my orders until you saw me jump up and hurry down the track. And, by jingo! had I been half a minute later, I should have had the devil to settle with."

We sat for a while listening to the incessant clicking of the three telegraph instruments, and then our curiosity got the better of us.

"Tell us, my friend," I said, "what are all these instruments talking about?"

His reply rather startled me.

"Well, I can't tell you exactly what they are saying. This one is a working wire of the _ Railroad. And this one is the working wire of the Railroad. It's wet weather now, and I can't take the stuff as well as when it's dry. Although, as I'm only a greenhorn, I can't take it very well at any time. I've only been at the business about three months, and this is the first time I've been left alone to run the office."

"How much do they pay you?"

" Oh, I don't get no pay. The station master gets all that."

"The station master? Who is he?"

"Sam Wright. He's the man that does all the telegraphing work when he's here."

"And why isn't he here now, instead of leaving a greenhorn to attend to his business?"

"Well, I'll tell you. You see, Sam is awfully stuck 


\section{A DANGEROUS RIDE}

on a girl down at Newcastle. So he says to me this morning, 'Bill, I hain't seen her for a week, and I can't stand it no longer. You take hold o' things and I'll run right down and come back Monday morning.' So he left me, and I tell you what, when I hear these instruments pounding away so fast that I can't understand half they are talking about, it shakes my nerves up awful. When I get a 'call' it's just as likely as not to come so fast I can't take a word of it."

There was quite enough in the greenhorn's information to set us soliloquizing on what might happen during Sam Wright's absence. Wouldn't it have been more considerate to let his girl wait rather than run the risk of launching a carload of people into Eternity? Of course it would; but a man troubled with "girl on the brain" has no spare room in that locality for the consideration of unpleasant possibilities.

Our soliloquy was here interrupted by one of the instruments clicking so vigorously that it drowned the noise of the others. We were sure it was a call for this station, because of the agonized expression that crept over the greenhorn's face as he tried to make out the fast coming message. While he could take some of it, there was evidently more of it that he couldn't take. So at last he was forced to ask the sender to "slow up." As it was now near our train time I asked him if the message he was taking had any reference to our train. 
"I'm not right sure, but I think it means that your train will be held at $\mathrm{M}$ —_ twelve miles from here, for No. 4 to pass her. (The trains were to have passed each other at our junction.) At any rate I am going to risk it, and notify the conductor of your train to wait there."

"But supposing," I said, "you are wrong about it, what then?"

"Oh, I guess it'll come out all right, because the man at $\mathrm{M}$ - I think will get orders to hold No. 4 there. At any rate, I'm doin' the best I can, and, if anything happens, your blood will be on Sam Wright's head, and not on mine."

This bit of information was not altogether pleasant. Blood is a precious commodity, or, at least, is so rated in the estimation of its owner. How much of it I may own, I know not; but whether it be enough to float a ship, or not enough to make a supper for a flea, I have no desire that it should make its abode on the top of Sam Wright's head, nor, for that matter, the head of any other fellow.

Our talk was now cut short by the arrival of the train that was to carry us on our way to MI- or possibly to some station in the other world. We stowed our luggage and dogs in the baggage car; then, discreetly picking out the two last seats in the train, we raised a window on either side of the car, and poked our heads out into the darkness. All the 


\section{A DANGEROUS RIDE}

greenhorn's telegraphic ignorance hovered over us like a nightmare, whispering to our heated imagination that a locomotive headlight would swing around the next curve, and "Number 4" would commence at once to scatter our blood on the top of Sam Wright's head.

I have traveled in my time many railway miles, some of which were long enough to worry my patience; but my recollection knows of none that can compare in length and worriment with those twelve miles to $\mathrm{M}$ -

They came to an end at last; and when they did we found Number 4 waiting for us on the siding. The greenhorn had taken the message right; our train was safe; and Sam Wright's head will have to wait awhile longer for its sanguinary sprinkle. 


\section{A Fight to the Death}

Both sides fiercely fought.

-HeNRY VI.

In the early summer of-well, it matters not what year, I was one of a few city men camped in the wilds of Pike County, Pa. Each of us expected to catch his complement of thirty-five lusty, speckled trout, which are all that the rules of the Beaver Run Club, whose guests we were, will allow any member to kill in any one season. Besides, every fish must be over eight inches in length, or back he goes into the stream.

Now, Japan is said to be the home of the rhododendron, the whole island kingdom being one great bed of those gorgeously dressed flowers. Pike County is the home of the mountain laurel and it grows and thrives there in the wildest luxuriance. It seems to flourish equally well on the ridges, in the thick clusters of the woods or by the edges of the trout ponds or their emptying streams.

When the bushes are in the glory of their bloom, swaying their mass of colors in the breeze-when the eye sees in the back and foreground the wealth of wild roses, the acres upon acres of blackberry bushes clothed in their snowy blossoms, the hazel and elder- 


\section{A FIGHT TO THE DEATH}

berry bushes and the hop vines weighted with rustic loveliness, then is our sense rapt with the picture, and Tom Moore's ecstatic outburst over the Vale of Cashmere comes to our recollection and leaps from our tongue :

\section{"What a wilderness of flowers!"}

The picture is full of Nature's dainty touches. She is a rare painter, and the man whose sense of beauty sleeps unroused by her miraculous coloring must be a clod, and his life can hardly be worth the living.

However, if the beauty of the flowers and the grasses and the lush meadows and the ripening fields of rye, waving their golden billows in the sunlightif all this pulchritude doesn't convince his eyes that Nature is marvelously nice in making up a summer toilet for Pike, perhaps her feathered warblers might appeal to another of his senses. Her songsters are here in wondrous variety and multiply amazinglywhich, by the way, is also true of some of her goodly game-birds, notably the quail, the ruffel grouse and the woodcock.

When I arrived here it was night and my ears were greeted only by the sad song of the whip-poor-will. He seemed ubiquitous, for I heard him reciting " the ballad of his grief" from every direction. Sunrise, however, put an end to his melancholy ditty, and then the bird concert began. To distinguish the 
several songster's was difficult. They all sang together and so lustily and well it was indeed hard to tell which was which. I listened, and by and by my ear recognized the warble of the gay-dressed oriole; then the sweet, loving song of the linnet; then the robin, the flicker, the catbird, the blue-jay and the song-sparrow, while from across a trout-pond the familiar note of Bob White rang out clear and sweet, piercing the morning air like the notes of a piccolo. Then a Wilson snipe started up and sivept away in the distance with its cry of "Scaip!" "scaip!" while a pair of sand-snipe joined their piping notes to the pleasing chorus. The red-winged blackbird and the mottle-breasted thrush, both volunteered their aid to the sunrise concert and were as blithe in the execution of their arias as the rest of the feathered tenors. But I mustn't forget to mention the leader of the troupe, the bobolink. I heard him pouring out his rollicking song, and he did it with such gusto I thought the pipes of his little throat would surely split.

Yes, the air was full of glee. But, while the birds sang and the bees worked and the trout leaped for the passing fly-while roseate shadows flecked the blue vault and kissed the brooks that babbled through the daisies-while joy and gladness reigned in Nature's realm and the good dame seemed to be chuckling over the cleverness of her own handiwork, Sorrow 


\section{A FIGHT TO THE DEATH}

lurked in the land of Pike. My friends and myself were gathered around the grateful log-fire in the clubroom and our talk turned chiefly upon this sorrow, coupled as it was with the tragic death of young Walter Clark. Walter was the son of Squire Clarka respected magistrate of the county-and the cause of the boy's death was a fight to the finish with a big and vicious rattlesnake. The snake won and the boy won, for each killed the other. "'Twas a fight to the death," and the story of it had to be told by conjecture. It took place in the seclusion of the woods, with no eye-witness, and one of the combatants was dead and the other unconscious when found. Walter Clark was a boy of eleven summers, sturdy and strong for his age, but a fever had left him, as a proof of its virulence, an impaired mind and imperfect speech. $\mathrm{He}$ had one marked trait-a strong antipathy to snakes and hornets and he would gladly fight either when opportunity offered. On the day of the fight the father was working in the field and Walter was helping him, barelegged, with but shirt and pants on. The boy heard the ringing of a cow-bell, and said to his father, "Cow ! cow!" His father replied: "Yes, I hear the bell," and went on with his work. The boy started down the road in the direction whence the sound came, and that was the last seen of him until a search was made over three hours after. He was found away from the road, swollen and uncon- 
cious, his tongue out and swelled to such a size that his mouth could not be shut. IIe was bitten on his hands, his arms, his face and his legs, and some twenty feet away from him lay a great rattlesnake with its back broken in three places and its fangs inserted in its own body, forming a loop.

It is supposed that the boy, after breaking the rattler's back, caught the reptile in his hands with the intention of crushing out its life; that it bit him over and over again wherever it pleased, and finally fastened its fangs in its own body. Then the supposition is that the boy grew weak from his wounds, dropped his hold of the rattler and fell back in a swoon.

A brother of Walter's, who was also a lad, found him where he lay and carried him on his back for over a mile and a quarter. Then the brother's strength gave out and he fell by the wayside. The father ran toward the two boys and at once commenced to doctor the wounded one. Repeated doses of whiskey and milk revived the boy for a while, and during the whole of his conciousness, and with fierce look and gesture, he would shout, "Dam'd snake! dam'd snake!" But convulsions soon set in and he died. His body became spotted like the snake's, with streaks on his chest and sides and spots upon his cheeks and brow.

A wagon was sent post-haste to Stroudsburg for a 
coffin, but as none could be had in that rustic town it was necessary to send to Easton for one. And so the plucky boy was laid beneath the sod, and the neighbors and visitors to this wild region revel in stories of snakes, of snake bites and snake fights, and the men hereabouts look carefully where they tread, and jump at the rustle of every chipmunk. And the women-God bless 'em-they hug the safety of the boardinghouse or hotel porch and will not wander afield for love or money. And who can blame them? The fields and the woods and the groves of Pike swarm with the deadly rattlers and the women-again I say God bless 'em!-all know it. They take no stock in snakes of any sort. They haven't forgotten how one of these reptiles befooled the Mother of Mankind with honey and soft-soap and piled upon the shoulders of the world a pack of trouble under which it still staggers. No ; since the time of Eve and her mischievous apple all womankind have had a dread of snakes and always will have till the world grows gray and Time gives up the ghost. 


\section{A Pilgrimage to the "White"}

I'll drop me now the current of my sport

To loll awhile in Fashion's giddy court.

-ANon.

Although hunting occupies a big room in my heart it isn't the only recreation tenant. There is another one, and I now throw aside my rifle to speak of it. For a long time past I have been in the habit of making an annual pilgrimage to the White Sulphur Springs-" "the Saratoga of the South." If the reader has ever been there he will possibly think, with me, that few portions of the globe can furnish more material for the pencil of the artist and the pen of the novelist. Where else can the eye feast more sumptuously than on the scenery of the White? Where else can be found more romantic beauty than lies cradled in its valleys? Behold them teeming with their fruitful crops and draped in luxuriant foliage through whose bosom peeps the humble cabin of some former slave, while here and there a more pretentious home lifts its trim roof above the green as if to greet the sun and sniff the bracing air. All this, and in a frame of rugged mountains enchanting in their wildness, and the picture is complete.

Thus much for the artist. As for the novelist, he 


\section{A PILGRIMAGE TO THE “WHITE” 333}

will find it a great gathering place for the wealth and beauty of the South; a place bubbling over with revelry, amusement, flirting, and love-making. He may witness there the excitement and seduction of the "green-baize table" and possibly find enough material to furnish a tragic chapter for his fiction. If he should need stories of the Civil War he can fill his brain-pan with any quantity of incidents that happened in and about the "White" during "our late unpleasantness."

The hotel was used, at one time, as a hospital for Northern troops; at another, as a stable and restingplace for the Confederates. Being only five miles from the Virginia line this watering-place was looked upon as neutral territory. Here, from the earliest days of the nineteenth century, presidents have spent their holidays and held court, and dispensed official patronage under the old oaks that lift their stately heads above the lawn. Here senators, representatives, governors and bankers have met on the hotel porches or under its cottage roofs and discussed their pet measures of national, state and financial policy.

A southern colonel who had lost everything during the war-except his love for whiskey-came to sojourn at the "White." He was never known to have any money, but was generally flitting around the bar, waiting for the refrain "come and take suthin', Colonel," which invitation he was never 
known to refuse. In consequence of these eccentricities he was looked upon with suspicion by the manager of the house, who promptly sent him his bill at the end of the week, together with a request to pay up. The colonel put the bill in his pocket and promised to attend to it. A couple of days passed and the manager stirred him up again, this time sending the message that he must either pay the bill or leave. The Colonel glared at the messenger savagely and then asked, "Did the manager send you to me with such a message?" The clerk timorously replied that he did. "Well," said the Colonel, "tell the manager that I'll leave at once, for that is only faar, and I believe in bein' faar." And he left the hotel. It need hardly be added that he left the hotel bill, too:

As I have said, the novelist might find around the "White" plenty of food for his fancy, full of richness flavored with facts and seasoned with all the spice of romance. The genial southern gentleman who is superintendent of the hotel, and known far and wide as "The Major," could, if he would, unwind many a yarn on the late "unpleasantness." $\mathrm{He}$ might, for instance, tell of the time when he, with a troop of Confederate cavalry commanded the bridge over the Greenbrier River, six miles below here-when he saw from the opposite hills an immense force of the "Boys in Blue" defiling down the long road-when he and his troop were discovered, and how the "Yanks" 

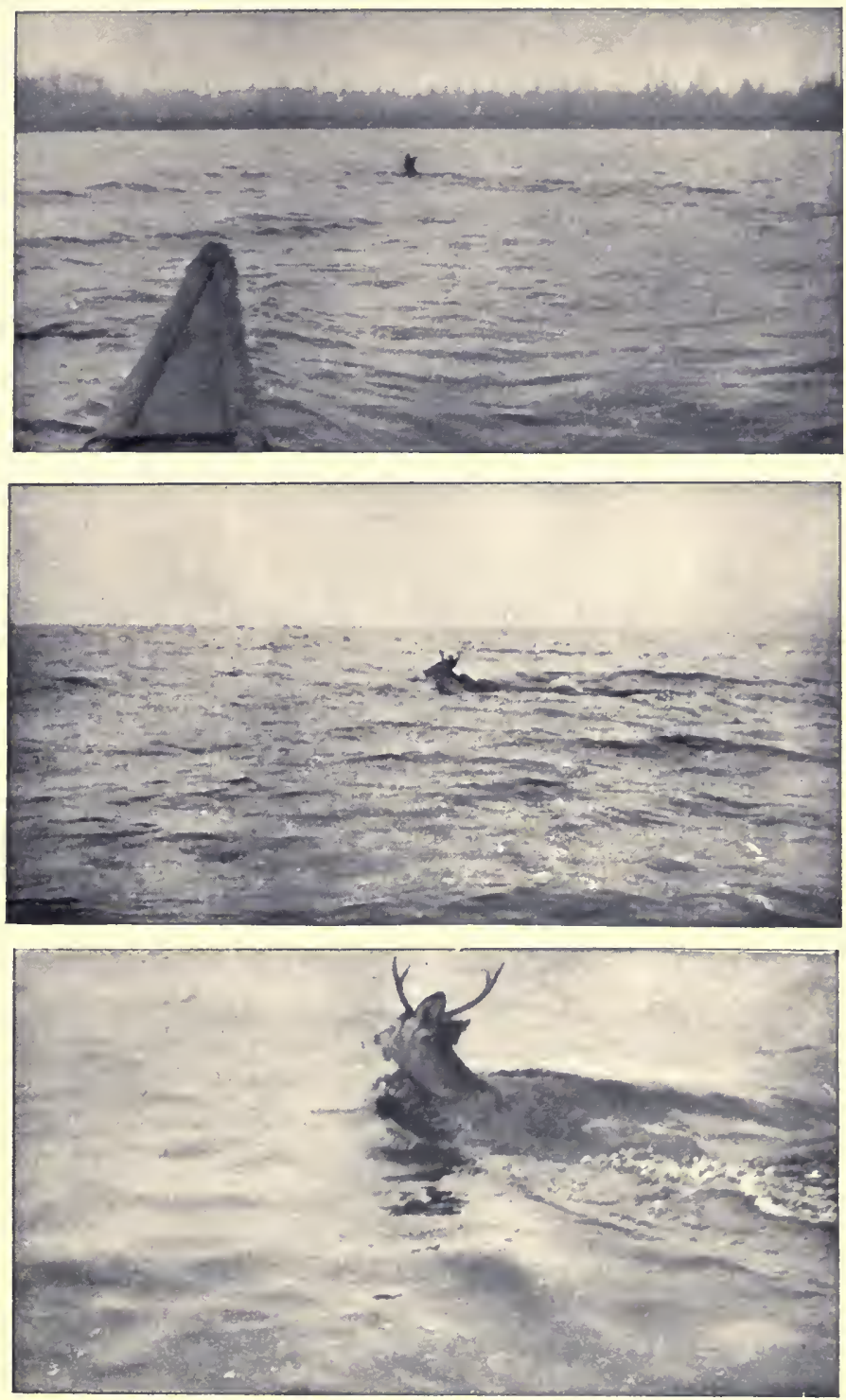

An Excitrug Chase 



\section{A PILGRIMAGE TO THE “WHITE” 337}

put spurs to their horses and the "Johnnies" started for safer quarters - how they came flying past the Grecian columns of the great hotel with the Yanks close at their heels-how they plunged through Dry Creek, up hill and down dale, and over the Alleghany Mountains to Old Sweet Springs, a ride of about twenty miles, before the pursuit and flight were over. And then the Major will probably wind up his yarn with "My command was safe and not a man lost!"

The Major's tales are always full of powder.

Eleven miles from the "White," is Lewisburg, W. Va., the county town of Greenbrier County. To reach it a high mountain has to be overcome, or overgone, on the higher points of which is a stretch of utterly worthless land. The soil, what little there is, is red, stony and incapable of producing anything better than an occasional thistle or a stunted, sickly, pine shrub. One hot day an old-time stage-coach was toiling slowly up the long hill, with its load of passengers who were making merry over the "pore land." One of them ventured the remark: "The man who owns that land must be a d-d fool." Thereupon a long, lanky West Virginian rose up and confronting the speaker in an angry and defiant manner said, "I own that land, but I'm not such a d-d fool as you take me for-I only own half on it."

Coming down from a horseback ride on Kate Mountain, one of West Virginia's giant hills, my son said 
to me, "Aren't these West Virginia mountaineers quaint people?" I readily answered that they were, for I have never seen their quaintness and a few of their other peculiarities equaled. Old-fashioned fellows, homely, frugal, careless of dress and the proprieties of life generally, eternal chewers of tobacco, iron-clad swearers, and always hard up. The current incidents of time have no claims on their attention, unless such incidents relate to the triumph of Democracy or the success of the season at the "White"; the latter more particularly, for on it is based their sole hope of seeing some ready cash during the year. This famous resort furnishes employment to about five hundred "help" in the summer, and maybe fifty or more the rest of the year; and thus it becomes the distributing source of a goodly number of thousands of dollars annually. It would be hard to compute the amount that liverymen, florists, photographers, doctors, musicians and the seductive gentlemen who preside over the fortunes of the "green table" rake in from the army of guests who patronize the "Saratoga of the South." Speaking of liverymen, one of them, an abominable swearer, promised me he would abandon the habit which I told him I abhorred. It seems, however, he forgot his promise. Here is his letter to me verbatim, which will tell how.

Pleas find enclosed fifteen dolers to pay youre bill. the reason of delay was, hard times, bad weather, sick- 


\section{A PILGRIMAGE TO THE “WHITE” 339}

ness and no money. $d-d$ if I believe there's $\$ 500$ in circulation in the hole United States.

Yours Truly

I reproached him for having broken his solemn word about swearing. "Well," he said, "I tried not to, but I couldn't help it; times were so awful pore. Why," said he, "I owed a man ten cents who lived eighteen miles off, and he drove in one day and sat around for over an hour when he said he wished I would pay him that ten cents, as he had driven all the way in after it, which would make the round trip thirty-six miles for ten cents." He told this incident to prove the scarcity of money in his locality.

Last year a lumberman who had drifted into financial difficulties allowed three notes which I held against him to go to protest. I was advised to give them to a firm of lawyers in a neighboring town to collect. So I drove over and found that the firm consisted of two brothers, one of whom was that very day in the height of excitement, running as a candidate for a public office of a responsible and honorable character. After a chase I finally captured the other brother and gave him the notes for collection. $\mathrm{He}$ said he guessed there wasn't much use, but he'd try his best; and putting the notes in his pocket drove off. Last week I happened to meet the maker of the notes, who was joyous over the fact that he would soon be able to pay off his creditors and asked after 
the three notes. I told him to whom I had given them for collection, but he said he had never heard from them. He advised me to ride to the town and get them; so next day I started over the mountains to see the legal lights. On the road I met my friend the lumberman coming back, and he reported that the lawyers had no recollection of my claim whatever.

On my arrival I found the pundits in a little upstairs room and seated at a table covered with envelopes, opened letters, bills of sale, bonds, writs of replevin, leases, promissory notes and various legal documents probably loaded with trouble for somebody.

The elder brother was a genial, kindly-looking man, with an old straw hat, a shirt much the worse for wear, and no coat, vest, collar or necktie. He assured me, when I told him who I was, that he had promptly presented my claim to the lumberman, but he found that if he sued he hadn't any chance, and so had waited. I asked for the return of the notes. Then a hunt was started, and such a hunt as only the immortal Dickens could, with justice, have described. Brother number one looked through the letters, papers and portfolios at his side of the table. Brother number two ditto at his side. The day was hot, muggy and oppressive, and the note-hunters grew worried, excited and nervous. Brother number two said he guessed he'd go home and look through his clothes, 


\section{A PILGRIMAGE TO THE “WHITE" 341}

which he did, brother number one in the meantime going through his printed blanks in his search. Brother number two finally returned without the notes and gave it as his opinion that I had never given him any notes. This was awkward on number one, because he had related very minutely just how he had presented them to the debtor.

So it was, as an Irishman said, "like bein" in the cinther of a hobble," and with a look of despair they gave up the hunt and acknowledged they would have to give the debtor a bond to keep him harmless from the notes if they ever turned up. Their only apology for their carelessness was that "notes in West Virginia ain't much account, no how, when they'd got to be sued for," and so they didn't "set much store by them."

At the lumbering town of Ronceverte, W. Va., eleven miles below on the Greenbrier River, a great boom and a gigantic saw mill had for years impeded the passage of black bass, trout and other fish up the river which in olden times was always a noted stream for the bass. The fish used to be of immense size, and, of course, as gamey as black bass can be in cold, mountain streams. Early one spring the ice and winter floods caused a break in the big dam which took considerable time in repairing, and behold, the following summer found the river full of the fighting beauties voraciously hungry to take fly, minnow, or 
even bait. In season it affords fishing "as is fishing," and the Izaak Waltons wend their way thither from distant parts to pursue their fascinating sport. Among these Waltons may be found all sorts and conditions of men from the sole President of the United States down to the multitudinous John Smith.

Verily, the old Anglo-Saxon love of sport must have been born in us. It sways the lives of us all, else why should the shibboleth of black bass be more potent than the seductive charms of polite society, the beneficial properties of the White's waters, or even the cuisine delicacies of its great hotel? But so it is ; and I, for one, should be sorry to have it otherwise.

Yet, stay a moment. I have been too hasty in conceding so broad a sway to this Anglo-Saxon love of sport. I should have excepted that anomalous tribe of men for whose benefit this book is written and to whom the writer will now preach a short, ding-dong sermon. It is quite likely they will turn a deaf ear to the ding-dong and pronounce the preacher a onestringed harper and a crank of a tautophone. Perhaps he is; yet if there be any American business men whose eardrums are not split by the jingling of dollars, they may now hear some wholesome strains from his single string and ought to be delighted to find so much benign melody in the crank of a tautophone. Gentlemen-drudgers of humanity, your train of thought, freighted with funny notions of felicity, 


\section{A PILGRIMAGE OF THE “WHITE” 343}

is on the wrong track. Switch off-the quicker the better-and back out from the dangerous hallucination that the piling of money is the top and bottom of human bliss. Life is not made up of dollars and cents, nor does its chief enjoyment lie in scraping them together. As you surely know it can be lived but once, shouldn't you like to hang on to your scarce and slippery "once" as long as possible? Of course you should and therefore 'twould be wise to drop your drudgery for a while and spend a little of your time and more of your pile in the pursuit and capture of Health. However, don't mistake my meaning. I am quite aware that money cannot purchase Health, though it may buy doctors by the gross and physic by the cartload. But it may lure the hygienic dame in a roundabout way. It can bribe her handmaid Recreation, whose services will wriggle you into the good graces of her mistress, and quicker than all the world's doctors or the swallowing of their questionable physic. Selah. 


\section{The Last Shot}

- Have you with heed perused

What I have written to you?

-Coriolanus.

Plutarci says: "Recreation is the sweet sauce of labor," a fact of which the American business man, who usually swallows his labor with no sauce at all, should make a note.

\section{"What so strong}

But wanting rest, will also want the might?

The Sun that measures heaven all day long, At night doth bait his steeds the ocean waves among."

The labors of old Sol, to be sure, are a little out of the line of the business man, but not so much out of it that he can afford to disregard the example or declare that rest and recreation are but snares,

Delusions mere, inventions of the devil,

to bamboozle the thrifty and keep up the world's stock of drones. If the devil did invent them I have a much higher opinion of him than usually obtains, and the proverb is right-the old fellow is " not as black as he's painted."

What I have recited in the foregoing pages comprises but a few of the many pleasant and exciting in- 


\section{THE LAST SHOT}

cidents and experiences enjoyed in my tussle with the wilds of Nature. Though the time was comparatively short the trips were not. By land and water, by rail, steamboat, wagon, buck-board, yacht, row-boat and birch-bark canoe, the miles covered were over ten thousand. No trifling distance; and yet through it all I was never really ill but once, and the damage done then was not serious enough to prevent my returning home,

\footnotetext{
"Full of vigor, tough and glad, Feeling like a wiry lad,"
}

and with a capacity for work that was well worth its cost of two months' time.

And now a parting word to you, you man of business, chained like a felon in his cell, bereft of sunlight, harassed with care, tiring your brain over the one mighty problem of money-making-or else some scheme to stave off financial disaster-'twill pay you to ponder on my words and my experience and call a halt. Make up your mind that money without health is a greater calamity than health without money. Leave your desk and turn your back on the steaming streets of civilization and your thoughts where Nature tempts with her trout streams, her mirrored lakes and her game-abounding retreats ; to her forests, fragrant with balsamic odors and watered with living streams made wholesome with the leechings of the spruce, and pine, 


\section{SPORT INDEED}

and cedar-Nature's own nectar; a draught of it and you'll need no other stimulant. Then when the day's sport is over and the night comes, what a revelation is in store for you! Cuddled in your warm sleeping-bag, with plenty of blankets, you "lay me down" on your bed of spruce boughs, whose odors play thick about you, filling the air and soothing you quickly into babelike slumber. In the morning, spryer than the sun, you leave your bed before him, armed with a doubleedged appetite so keen and new you wonder where it came from. Trust me for what I tell you, and my words but faintly speak the novel joys which await. you. Once more I say, forget "the shop" and all which that implies, and with the Poet Rowe you may exclaim to some purpose :

"Begone my cares! I give you to the winds."

T. M. 



UNIVERSITY OF CALIFORNIA LIBRARY

Los Angeles

This book is DUE on the last date stamped below. 
